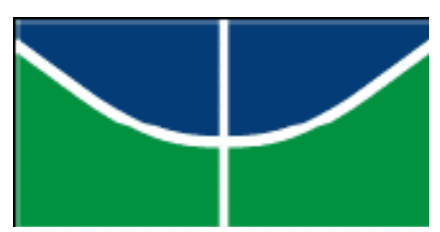

UNIVERSIDADE DE BRASÍLIA

Instituto de Ciências Biológicas

Instituto de Física

Instituto de Química

Faculdade UnB Planaltina

Programa de Pós-Graduação em Ensino de Ciências

Mestrado Profissional em Ensino de Ciências

\title{
A ABORDAGEM DE MODELOS ATÔMICOS PARA ALUNOS DO 9॰ ANO DO ENSINO FUNDAMENTAL PELO USO DE MODELOS E MODELAGEM NUMA PERSPECTIVA HISTÓRICA
}

JÉSSIKA SILVA DE ANDRADE 


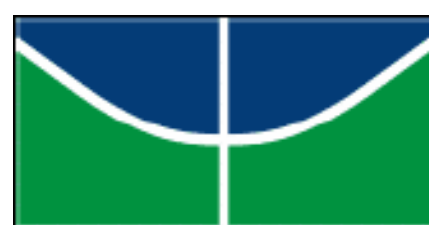

\title{
UNIVERSIDADE DE BRASÍLIA
}

Instituto de Ciências Biológicas

Instituto de Física

Instituto de Química

Faculdade UnB Planaltina

Programa de Pós-Graduação em Ensino de Ciências

Mestrado Profissional em Ensino de Ciências

\section{A ABORDAGEM DE MODELOS ATÔMICOS PARA ALUNOS DO 9 ANO DO ENSINO FUNDAMENTAL PELO USO DE MODELOS E MODELAGEM NUMA PERSPECTIVA HISTÓRICA}

\author{
JÉSSIKA SILVA DE ANDRADE
}

Dissertação realizada sob orientação da Prof. ${ }^{a}$ Dr. ${ }^{a}$ Renata Cardoso de Sá Ribeiro Razuck e apresentada à banca examinadora como requisito parcial à obtenção do Título de Mestre em Ensino de Ciências - Área de Concentração "Ensino de Química", pelo Programa de Pós-Graduação em Ensino de Ciências da Universidade de Brasília. 
Ficha catalográfica elaborada automaticamente, com os dados fornecidos pelo(a) autor(a)

A553a

Andrade, Jéssika Silva de

A abordagem de modelos atômicos para alunos do $9^{\circ}$ ano do ensino fundamental pelo uso de modelos e modelagem numa perspectiva histórica / Jéssika Silva de Andrade; orientador Renata Cardoso de Sá Ribeiro Razuck. -- Brasília, 2015.

$156 \mathrm{p}$.

Dissertação (Mestrado - Mestrado

Profissionalizante em Ensino de Ciências) -Universidade de Brasília, 2015.

1. Ensino de ciências. 2. Modelos atômicos. 3. Livro didático. I. Razuck, Renata Cardoso de Sá Ribeiro, orient. II. Título. 


\section{FOLHA DE APROVAÇÃO}

Jéssika Silva de Andrade

"A abordagem de modelos atômicos para alunos do 9o ano do Ensino Fundamental pelo uso de modelos e modelagem numa perspectiva histórica"

Dissertação apresentada à banca examinadora como requisito parcial à obtenção do Título de Mestre em Ensino de Ciências pelo Programa de Pós-Graduação em Ensino de Ciências (PPGEC) da Universidade de Brasília (UnB).

Aprovada em 24 de abril de 2015.

\section{BANCA EXAMINADORA}

Prof. ${ }^{\text {D }}$ Dr. ${ }^{\text {a }}$ Renata Cardoso de Sá Ribeiro Razuck - IQ/UnB (Presidente) Prof. ${ }^{\text {a }}$ Dr. a Jeane Cristina Gomes Rotta - FUP/UnB
(Membro Titular)

Prof. Dr. Roberto Ribeiro da Silva - IQ/UnB (Membro Titular)

Prof. Dr. Eduardo Luiz Dias Cavalcante - IQ/UnB (Membro Suplente) 
Dedico este trabalho

À minha amada família,

Ao meu amado noivo,

À minha querida orientadora. 


\section{AGRADECIMENTOS}

Agradeço primeiramente a Deus, autor da vida, por ter me sustentado em todos os momentos da minha vida.

Aos meus amados pais, Marcelo e Neide, por sempre terem me apoiado e se esforçado de todos os modos para que eu pudesse chegar até aqui.

À minha querida orientadora Renata por ter aceitado estar nessa jornada comigo, pelo carinho, compreensão e dedicação e por seus ensinamentos desde a graduação sem os quais eu não conseguiria chegar até aqui.

Ao meu amado noivo Higor que com toda paciência soube me compreender e nos momentos mais difíceis cuidou de mim.

Às minhas irmãs Luciene e Thalita e aos meus cunhados Joabe, Ruber e Thiago por estarem comigo nos momentos alegres e nos momentos difíceis e em especial à minha irmã Marcella por ter demonstrado o seu amor e apoio na prática não hesitando em acordar cedo para estar comigo durante toda a aplicação da proposta.

Ao meu irmão do coração Vinícius Eduardo por sua companhia alegre e descontraída.

Aos meus demais familiares por acreditarem em mim quando eu mesma duvidei.

A todos os meus amigos, em especial ao meu grande amigo André Luiz, por compreenderem a ausência e por terem sempre me apoiado.

Aos professores do PPGEC pelos ensinamentos e contribuições com este trabalho, aos colegas de mestrado pelas palavras de incentivo e à secretaria, em especial à Luciene, pela disponibilidade e pelo auxílio afetuoso.

Aos membros da banca pelo aceite e pelas imensuráveis contribuições a este trabalho.

Aos alunos do Centro Educacional 03 de Sobradinho que participaram da pesquisa e ao professor Marcos por ter cedido algumas de suas aulas e por ter contribuído de forma valiosa com a execução da proposta.

A CAPES pela bolsa concedida. 
"A pessoa sábia está sempre ansiosa e pronta para aprender."

Provérbios 18.15 


\section{RESUMO}

O ensino de modelos atômicos no $9^{\circ}$ ano do Ensino Fundamental não tem alcançado os objetivos propostos da maneira que tem sido abordado. Aspectos como a não valorização da construção histórica dos modelos, o alto grau de abstração dos conteúdos, a forma acabada e imutável como esses são apresentados e as distorções conceituais presentes nos livros didáticos têm influenciado negativamente na aprendizagem desses conteúdos. Tendo essa problemática em vista e considerando a importância que o livro didático tem no processo de ensino-aprendizagem, o presente trabalho se propôs a verificar a abordagem dos conceitos de átomo nos livros didáticos aprovados pelo Programa Nacional do Livro Didático/2014 (PNLD/2014) e a pesquisar se a utilização de modelos e modelagem numa abordagem histórica e experimental poderia auxiliar na apropriação do conceito de modelos atômicos por alunos do $9^{\circ}$ ano do Ensino Fundamental. Foram analisados exemplares das obras aprovadas no PNLD/2014 nas quais os conteúdos referentes aos modelos atômicos são abordados. Para responder a pergunta proposta elaboramos uma proposição didática para o ensinoaprendizagem dos conceitos de átomo a partir da inserção de estratégias como aulas dialógicas, experimentação e construção de modelos, diferentes daquelas propostas nos livros didáticos. A proposição foi implementada em uma escola pública da Regional de Ensino de Sobradinho, Distrito Federal, no início do segundo semestre de 2014. Os resultados apontam que, dentre os livros verificados, aqueles que abordam os modelos atômicos (equivalente a 90\%) o fazem de forma não recomendada pelos PCN, ou seja, com aprofundamentos relacionados ao átomo. Além dos aprofundamentos, não há muita variação nas estratégias de ensino propostas e essas não se mostram adequadas e/ou colaboradoras para uma aprendizagem efetiva dos conceitos. $\mathrm{O}$ módulo didático se mostrou eficaz quanto ao alcance de seus objetivos. As estratégias e recursos utilizados possibilitaram a aprendizagem dos conceitos de átomo. Quanto à abordagem da construção histórica dos conceitos químicos, foi possível constatar que essa pode colaborar para que os alunos desmistifiquem o caráter acabado e imutável das descobertas científicas.

Palavras-chave: Ensino de Ciências, Modelos atômicos, Livro didático. 


\begin{abstract}
The teaching of atomic models in the 9th grade of elementary school has not reached the proposed objectives of the way it has been approached. Aspects such as no appreciation of the historical construction of the models, the high degree of abstraction of the contents, the finished state, immutable as these are presented and the conceptual present distortions in textbooks have negatively impacted on learning such content. With this problem in mind and considering the importance that the textbook is in the process of teaching and learning, this study aimed to verify the approach of atom concepts in textbooks approved by the National Program Textbook / 2014 (PNLD / 2014) and to investigate the use of models and modeling in a historic and experimental approach could assist in the appropriation of the concept of atomic models for students in 9th grade of elementary school. Specimens were analyzed works approved in PNLD / 2014 in which the content relating to atomic models are addressed. To answer the question posed elaborate a didactic proposal for the teaching and learning of atom concepts from the insertion strategies as dialogical classes, trial and building models, different from those proposed in textbooks. The proposal was implemented in a public school of the Regional Education Sobradinho, Distrito Federal, early in the second half of 2014. The results show that among the scanned books, those that address the atomic models (90\% equivalent) do to form by PCN not recommended, ie insights related atom. In addition to the insights, there is not much variation in the proposed teaching strategies and these just are not suitable and / or collaborators for effective learning of concepts. The teaching module was effective as to achieve their objectives. The strategies and resources used enabled the learning of atom concepts. On the approach of the historical construction of chemical concepts, it was found that this can collaborate so that students may unveil the finished and immutable character of scientific discoveries.
\end{abstract}

Keywords: Science education, Atomic models, Textbook. 


\section{LISTA DE ILUSTRAÇÕES}

Figura 1 - Relacionamento entre as principais etapas envolvidas na modelagem. $\quad 39$

Figura 2 - Caixas utilizadas na realização da atividade "Imaginando o invisível”. 56

Figura 3 - Objetos que foram colocados dentro das caixas ilustradas na figura $2 . \quad 56$

Figuras 4 e 5 - Desenvolvimento da atividade "Imaginando o invisível". 58

Figura 6 - Desenho produzido pelo grupo 1.

Figura 7 - Desenho produzido pelo grupo $2 . \quad 58$

Figura 8 - Desenho produzido pelo grupo $3 . \quad 58$

Figura 9- Desenho produzido pelo grupo $4 . \quad 59$

Figuras 10 e 11 - Representação do átomo de Dalton construída por um aluno. $\quad 64$

Figuras 12, 13 e 14 - Representação de substâncias simples e compostas segundo o modelo de Dalton construída por um aluno. 64

Figuras 15 e 16 - Representação de substâncias simples e compostas segundo o $\begin{array}{ll}\text { modelo de Dalton modificado construída por um aluno. } & 67\end{array}$

Figura 17 - Momento da realização do experimento "Atritando corpos”. 69

Figura 18 - Momento da exposição da esfera de raios. $\quad 69$

Figura 19 - Bolo servido no início da aula. 77

Figuras 20, 21 e 22 - Representação do átomo de Thomson construída por um aluno. 77

Figura 23 - Realização do primeiro experimento. 83

Figura 24 - Realização do segundo experimento. 83

Figura 25 - Realização do terceiro experimento. 83

Figuras 26, 27, 28, 29, 30 e 31 - Representação do átomo de Rutherford construída por um aluno. $\quad 84$

Figuras 32 e 33 - Realização do "Teste de chamas". 88

Figuras 34 e 35 - Desenho representado pela categoria F da tabela 23.

Figura 36 - Desenho representado pela categoria E da tabela 25.

Figura 37 - Desenho representado pela categoria F da tabela 25.

Figura 38 - Desenho representado pela categoria G da tabela 25.

Figura 39 - Desenho representado pela categoria I da tabela 27.

Figura 40 - Desenho representado pela categoria J da tabela 27.

Figura 41 - Desenho representado pela categoria K da tabela 27.

Figura 42 - Desenho representado pela categoria L da tabela 27. 
Figura 43 - Desenho representado pela categoria I da tabela 29.

Figura 44 - Desenho representado pela categoria J da tabela 29.

Figura 45 - Desenho representado pela categoria K da tabela 29. 


\section{LISTA DE TABELAS}

Tabela 1 - Respostas da questão 1 da Avaliação da Aprendizagem 1. 60

Tabela 2 - Respostas da questão 2 (parte a) da Avaliação da Aprendizagem 1. 61

Tabela 3 - Respostas da questão 2 (parte b) da Avaliação da Aprendizagem 1. 61

Tabela 4 - Respostas da questão 3 da Avaliação da Aprendizagem 1. 62

Tabela 5 - Respostas da questão 1 (parte a) da Avaliação da Aprendizagem 2.

Tabela 6 - Respostas da questão 1 (parte b) da Avaliação da Aprendizagem 2.

Tabela 7 - Respostas da questão 2 da Avaliação da Aprendizagem 2. 71

Tabela 8 - Respostas da questão 3 da Avaliação da Aprendizagem 2. 72

Tabela 9 - Respostas da questão 4 da Avaliação da Aprendizagem 2.

Tabela 10 - Respostas da questão 5 da Avaliação da Aprendizagem 2.

Tabela 11 - Respostas da questão 1 da Avaliação da Aprendizagem 3.

Tabela 12 - Respostas da questão 2 da Avaliação da Aprendizagem 3.

Tabela 13 - Respostas da questão 1 da Avaliação da Aprendizagem 4.

Tabela 14 - Respostas da questão 2 da Avaliação da Aprendizagem 4.

Tabela 15 - Respostas da questão 3 da Avaliação da Aprendizagem 4.

Tabela 16 - Respostas da questão 1 da Avaliação da Aprendizagem 5.

Tabela 17 - Respostas da questão 2 da Avaliação da Aprendizagem 5.

Tabela 18 - Respostas da questão 1 da Avaliação da Aprendizagem 6.

Tabela 19 - Respostas da questão 2 da Avaliação da Aprendizagem 6.

Tabela 20 - Respostas da questão 3 (parte a) da Avaliação da Aprendizagem 6.

Tabela 21 - Respostas da questão 3 (parte b) da Avaliação da Aprendizagem 6.

Tabela 22 - Respostas da questão 4a (parte a) da Avaliação da Aprendizagem 6. 92

Tabela 23 - Respostas da questão 4a (parte b) da Avaliação da Aprendizagem 6.93

Tabela 24 - Respostas da questão 4b (parte a) da Avaliação da Aprendizagem $6 . \quad 93$

Tabela 25 - Respostas da questão 4b (parte b) da Avaliação da Aprendizagem 6. $\quad 94$

Tabela 26 - Respostas da questão 4c (parte a) da Avaliação da Aprendizagem 6. 95

Tabela 27 - Respostas da questão 4c (parte b) da Avaliação da Aprendizagem 6.

Tabela 28 - Respostas da questão 4d (parte a) da Avaliação da Aprendizagem 6. 97

Tabela 29 - Respostas da questão 4d (parte b) da Avaliação da Aprendizagem 6. 98

Tabela 30 - Respostas da questão 5 da Avaliação da Aprendizagem 6. 


\section{LISTA DE QUADROS}

Quadro 1 - Estrutura do módulo didático.

Quadro 2 - Resultado da verificação da abordagem dos modelos atômicos nos livros didáticos aprovados pelo PNLD/2014. 


\section{LISTA DE SIGLAS}

AA1 - Avaliação da Aprendizagem 1 AA2 - Avaliação da Aprendizagem 2 AA3 - Avaliação da Aprendizagem 3 AA4 - Avaliação da Aprendizagem 4 AA5 - Avaliação da Aprendizagem 5 AA6 - Avaliação da Aprendizagem 6 MEC - Ministério da Educação PCN - Parâmetros Curriculares Nacionais PNLD - Programa Nacional do Livro Didático PPGEC - Programa de Pós-Graduação em Ensino de Ciências Prodocência - Programa de Consolidação das Licenciaturas SEDF - Secretaria de Educação do Distrito Federal UnB - Universidade de Brasília 


\section{SUMÁRIO}

INTRODUÇÃO

1. O ENSINO de CiÊNCIAS No ENSINO FUNDAMENTAL 23

1.1 Porque Ensinar CiÊNCIAS no Ensino Fundamental 23

1.2 OBSTÁCUlOS AO ENSINO DE CIÊNCIAS 25

1.3 CONCEPÇÕES ATOMISTAS DOS ESTUdANTES

2. O Ensino de Modelos Atômicos e os Parâmetros Curriculares NACIONAIS

2.1Os Modelos Atômicos nOS PARÂMETROS CURricUlares NACIONAIS 29

3. O Ensino de Modelos Atômicos e as Orientações Curriculares 32

3.1 Os MOdelos AtÔMICOS NAS ORIENTAÇÕES CURRICUlARES 32

4. O Programa Nacional do Livro Didático 34

4.1 CONTRIBUiÇÕES DO PROGRAMA NACIONAL DO LiVRo DidÁtico PARA A SELEÇÃo dos LiVRos DidÁticos 34

4.2 SELEÇÃo dos LiVRos DidÁticos de CiÊNCIAS 35

5. O Uso de Modelos no EnSINo de CiÊnCIAS 37

5.1 Conceituando Modelo E Modelagem 37

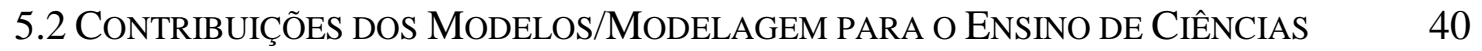

6. O PAPel da Experimentação no EnSino de CiênCIAS 42

6.1 CONTRIBUiÇÕES DA ATIVIDADE EXPERIMENTAL PARA O ENSINO DE CIÊNCIAS 42

7. Metodologia $\quad 48$

7.1 DesCrição MetodológiCa da PesQuisa 48

7.2 SuJEITOS PARTICIPANTES DA PESQUiSA

7.3 INSTRUMENTOS DA PESQUISA 49

8. Resultados

8.1 O Ensino de Modelos Atômicos nos LiVRos Aprovados PELo PNLD/2014 52

8.2 O ENSINO DE Modelos ATÔMICOS POR MEIO DO Módulo DidÁtico 55

8.2.1 PRIMEIRO MOMENTO 56

8.2.2 SEGUNdO MOMENTO

8.2.3 TERCEIRO MOMENTO

8.2.4 QUARTO MOMENTO 76

8.2.5 QUINTO MOMENTO 81 
CONSIDERAÇÕES FINAIS

101

REFERÊNCIAS BIBLIOGRÁFICAS

104

APÊNDICES 


\section{INTRODUÇÃO}

Quando ingressei no Mestrado do Programa de Pós-Graduação em Ensino de Ciências (PPGEC) da Universidade de Brasília (UnB) em 2013 ainda não tinha experiência profissional. Ao concluir o curso de Licenciatura em Ciências Naturais minhas experiências se restringiam à participação em projetos de iniciação à docência, executados ainda durante o período de graduação.

Dentre os projetos que participei o que mais me aproximou da prática docente foi o Programa de Consolidação das Licenciaturas - Prodocência, que consistia no estabelecimento de parcerias entre a universidade e escolas de Educação Básica da rede pública local, visando melhorias na formação inicial dos professores. Os participantes desenvolviam projetos de intervenção, que se estabeleciam de acordo com o contexto em que cada escola estava inserida, auxiliados por professores da escola e da universidade. Apesar de muito ter contribuído com a minha formação inicial, os trabalhos desenvolvidos nas escolas proporcionaram experiências que se diferem da realidade de assumir uma classe como professora titular, o que até então eu não havia vivenciado.

Minha maior motivação em cursar o mestrado era a busca pelo conhecimento. Eu queria ir além do que a graduação me proporcionava, mas até esse momento a pós-graduação era uma oportunidade para um alvo indefinido. Pelo fato de esse ser um mestrado profissional cheguei a me perguntar se eu estaria no lugar certo. Passei por intensos momentos de dúvida em que eu me questionava a respeito das contribuições que eu poderia ou não dar ao programa. Eu me perguntava: Como poderei me profissionalizar em uma profissão que eu ainda não exerço? Mas não demorou muito para que eu iniciasse minha carreira profissional como professora de Ciências para o Ensino Fundamental em uma escola particular de Planaltina - DF. A partir desse momento, não foi difícil perceber em um curto espaço de tempo que esse era o lugar certo e essa a hora certa.

Deparei-me na escola em que eu iniciei o meu trabalho como professora com diversas situações práticas que se opunham a muitas teorias estudadas e defendidas durante a graduação. Por vezes ouvi pessoas dizerem que "Na prática, a teoria é outra" ou que "Entre a teoria e a prática existe um abismo", mas ao mesmo tempo eu pensava que essa distância não poderia ser tão exorbitante, pois que sentido haveria em estudá-las, então? 
Após algum tempo analisando um conjunto de possibilidades a serem pesquisadas, já que as inquietações frente ao ensino eram muitas, veio-me o interesse em pesquisar a respeito do ensino de modelos atômicos. A motivação em cursar o mestrado já não era mais somente a busca pelo conhecimento, mas a busca por um conhecimento que me levasse a contribuir com problemas reais que agora eu vivenciava como professora. Os problemas diagnosticados foram vários, eu me convencia cada vez mais da necessidade e importância de pesquisas que pudessem contribuir de alguma forma com a qualidade do ensino escolar.

E por que, dentre tantos problemas, pesquisar sobre o ensino de modelos atômicos? Além das observações feitas por mim e compartilhadas por colegas em relação às dificuldades na abordagem desse tema, um fator que muito contribuiu com essa escolha foi a minha experiência como aluna no processo de ensino-aprendizagem dos conteúdos relacionados aos modelos atômicos no Ensino Fundamental e Médio há não mais que seis anos. Recordo-me que os conceitos abordados não faziam muito sentido para mim, eram abordados de forma descontextualizada e apesar de estudar aquela "coisa" muito pequena, eu não sabia de onde vinha ou o porquê de aprender aquilo. É lamentável dizer que de lá para cá, como mostram diversas pesquisas recentes, as coisas não mudaram muito. Devido aos processos de ensino inadequados os alunos têm saído do Ensino Básico com concepções atomistas errôneas e a aprendizagem distorcida de inúmeros conceitos (POZO e CRESPO, 2009), como veremos mais adiante.

Diante das peculiaridades da disciplina de Ciências no $9^{\circ}$ ano do Ensino Fundamental, pesquisaremos nesse trabalho sobre a abordagem do conceito de átomo nessa série escolar. Vale ressaltar que a grande maioria das pesquisas realizadas no país relacionadas ao atomismo é direcionada ao Ensino Médio (FRANÇA, MARCONDES e Do CARMO, 2009; PEDUZZI e BASSO, 2005; LEITE, SILVEIRA e DIAS, 2006 e; MARQUES e CALUZI, 2003) e pouco se tem publicado a respeito da abordagem desse conceito no Ensino Fundamental (MORTIMER, 1995 e; GOMES e OLIVEIRA, 2007), embora esse seja um tópico frequentemente abordado nesse nível de escolarização, o que justifica a importância dessa pesquisa.

Concordamos com França, Marcondes e do Carmo (2009) quando afirmam que o conceito de átomo é pré-requisito essencial para a compreensão de conteúdos posteriores. Tal característica atribui grande importância à aprendizagem consistente desse conceito. Porém, diversos autores constataram que na maioria das vezes não há a compreensão do conceito de 
átomo. Na literatura encontramos diversas justificativas para a não aprendizagem do tema modelos atômicos, tais como:

1. a não valorização da construção histórica de tais modelos (FRANÇA, MARCONDES e do CARMO, 2009);

2. o fato de o átomo ser uma realidade impossível de ser vista (FRANÇA, MARCONDES e do CARMO, 2009);

3. a não contextualização do conteúdo nos livros didáticos (PEDUZZI e BASSO, 2005);

4. as distorções conceituais presentes ainda nesses livros (LEITE, SILVEIRA e DIAS, 2006);

5. a fragmentação dos conteúdos (LIMA, ROTTA e RAZUCK, 2011 e; MILARÉ, 2008);

6. o preparo acadêmico insuficiente de professores que não lhes têm permitido uma atuação adequada na abordagem desse tema (MARQUES e CALUZI, 2003);

7. a forma acabada e imutável como o mesmo é apresentado (MARQUES e CALUZI, 2003) e;

8. o uso desordenado de analogias, metáforas, imagens e modelos (GOMES e OLIVEIRA, 2007).

Quando França, Marcondes e do Carmo (2009) citam a abordagem da construção histórica do conhecimento científico, se referem às alterações que os modelos atômicos tiveram ao longo do tempo desde que os primeiros conceitos e modelos foram propostos. De forma geral, os conceitos químicos têm sido levados para a sala de aula em sua forma atualmente aceita pela comunidade científica sem que sejam feitas referências aos procedimentos executados para se chegar à estrutura atual. Essa abordagem não favorece o olhar crítico dos alunos para a Ciência, ao contrário, ela enfatiza a imutabilidade dos conhecimentos científicos. Para os autores as dificuldades ao longo do processo de construção do conhecimento e suas superações devem ser apresentadas aos alunos, sendo esta também uma forma de descaracterizar a aparência de conhecimento pronto e acabado que tem sido transmitido, conforme criticam também Marques e Caluzi (2003).

França, Marcondes e do Carmo (2009) falam ainda do alto grau de abstração do conteúdo. A impossibilidade de visualização do átomo aumenta a dificuldade de compreensão 
do mesmo que frequentemente é explicado de forma errônea pelos alunos que utilizam argumentos macroscópicos para esse fim. Pozo e Crespo (2009), ao abordarem a utilização do modelo corpuscular, citam que os alunos utilizam representações macroscópicas baseadas em estruturas simplificadoras para interpretar as relações entre as partículas, contrariando a teoria atômico-molecular que propõe a explicação de propriedades macroscópicas a partir do funcionamento das partículas. Tal fator é um dos que justificam a necessidade do uso de modelos no processo de ensino-aprendizagem desse conteúdo, sendo esses considerados ferramentas fundamentais já que permitem melhor compreender fenômenos não visíveis.

Mas é preciso ter cuidado. Como tantos outros recursos, os modelos, se utilizados de forma inadequada, podem promover uma aprendizagem distorcida dos conceitos. Conforme afirmam Pozo e Crespo (2009), a maioria dos alunos aceita os modelos como entes reais que os avanços tecnológicos e a pesquisa em Química permitiram descobrir ou ver. Faz-se necessário, portanto, conceituar o termo a fim de evitar possíveis distorções. Ferreira e Justi (2008), que se propuseram a pesquisar e fazer uso da modelagem em sala de aula, meio pelo qual obtiveram êxito ao ensinar conceitos químicos, definem modelo como:

[...] uma representação parcial de um objeto, evento, processo ou ideia, que é produzida com propósitos específicos como, por exemplo, facilitar a visualização; fundamentar elaboração e teste de novas ideias; e possibilitar a elaboração de explicações e previsões sobre comportamentos e propriedades do sistema modelado (FERREIRA e JUSTI, 2008, p. 32).

Peduzzi e Basso (2005), em um estudo sobre o ensino do átomo de Bohr, ao analisarem alguns livros didáticos, constataram que a maioria das obras não contextualiza adequadamente o conteúdo. Com relação ao termo contextualização, segundo Wartha, Silva e Bejarano (2013), diferentes significados são atribuídos a esse termo, porém o mais difundido na comunidade científica de educadores em ensino de Química diz que "Contextualização também é entendida como um dos recursos para realizar aproximações/inter-relações entre conhecimentos escolares e fatos/situações presentes no dia a dia dos alunos...” (p. 88). Adotaremos aqui esse conceito. Desse modo, torna-se extremamente relevante a prática de um ensino contextualizado que traga mais sentido para os conteúdos estudados, relacionando-os a vivência dos alunos. Ainda nessa linha, Fourez (2003) defende que os alunos estão interessados em um ensino de Ciências que os levem a compreender situações comuns do dia a dia e não que os obriguem a ter uma visão científica do mundo.

Em relação aos livros didáticos, as distorções conceituais neles presentes, as quais se referem Leite, Silveira e Dias (2006), devem ser tratadas com relevância visto que o livro 
didático é um dos principais recursos que alunos e professores têm acesso (ECHEVERRÍA, MELLO e GAUCHE, 2011), além de ser um recurso utilizado de forma quase que exclusiva por muitos professores. O Programa Nacional do Livro Didático (PNLD) - em seu âmbito atual, responsável por avaliar os livros didáticos propostos para o Ensino Fundamental e Médio - tem exercido um papel importante na seleção dos livros didáticos da rede pública de ensino. Mas, apesar das consideráveis melhorias já detectadas como resultado desse processo, ainda são encontrados erros conceituais, imagens impróprias e analogias inadequadas que proporcionam a aprendizagem distorcida dos conteúdos (MILARÉ e ALVES FILHO, 2010).

Echeverría, Mello e Gauche (2011) criticam ainda a seleção dos livros didáticos por professores que os escolhem de maneira pouco ou nada criteriosa. Eles atribuem essa incapacidade de análise crítica dos livros a pouca qualificação ou até mesmo experiência profissional. Ressaltam ainda que mesmo aqueles com formação específica e pedagógica na área apresentam dificuldades na identificação de erros conceituais e analogias inadequadas nos livros didáticos. Esse fato torna-se ainda mais preocupante visto que o livro didático não tem sido utilizado como um auxiliador no processo de ensino-aprendizagem, mas como um modelo-padrão, detentor de verdades absolutas.

Lima, Rotta e Razuck (2011) comentam sobre a fragmentação dos conteúdos de Física e Química abordados no $9^{\circ}$ ano do Ensino Fundamental que tem dificultado o processo de ensino-aprendizagem. Segundo as autoras, é comum que os conteúdos de Ciências no $9^{\circ}$ ano sejam apresentados de forma desvinculada entre si e com os demais conteúdos estudados anteriormente. Esse fato contraria a abordagem interdisciplinar e contextualizada dos conteúdos sugerida em documentos oficiais - como nos Parâmetros Curriculares Nacionais e nas Orientações Curriculares do DF - e desfavorece o desenvolvimento do senso crítico e da capacidade de relacionar os conteúdos ao contexto social em que o aluno está inserido.

Segundo Milaré (2008), essa compartimentalização torna-se ainda mais crítica quando o ensino de Ciências no $9^{\circ}$ ano é atribuído a profissionais especializados no ensino de Química ou de Física exclusivamente, de modo que cada professor atua individualmente por um semestre ou ao longo do ano - o que é muito comum nas escolas particulares. Além disso, os conteúdos abordados no Ensino Fundamental são resumos dos trabalhados no Ensino Médio, só que de forma superficial e inadequada. Como se não bastasse a complexidade inerente dos conteúdos, há ainda uma dificuldade na abordagem dos mesmos por profissionais mal formados que não possuem subsídios para inovar e contextualizar suas aulas que pouco têm contribuído para a formação crítica cidadã. Milaré e Alves Filho (2010) ressaltam que há 
deficiências tanto na formação específica quanto na formação pedagógica inicial dos professores. Corroborando com esse fato, o que se concebe no ensino tradicional é que “... para ensinar basta saber um pouco de conteúdo específico e utilizar algumas técnicas pedagógicas..." (SCHNETZIER e ARAGÃO, 1995, p. 27). Porém, sem formação adequada os professores não adquirem os requisitos necessários para a prática docente e acabam favorecendo a permanência de uma visão simplista da Ciência.

Ainda sobre o perfil dos professores de Ciências, Milaré e Alves Filho (2010) realizaram um estudo sobre a abordagem dos conteúdos de Química no $9^{\circ}$ ano do Ensino Fundamental e detectaram que dentre os entrevistados (um total de nove professores) nenhum dos profissionais que atuam em regência de Ciências é formado em Ciências Naturais. Desses, sete são formados em Ciências Biológicas e dois em Química. Segundo os autores, o professor de Ciências Naturais deve ser capaz de estabelecer relações entre as mais diversas áreas das Ciências, quesito que não tem sido suprido por tais profissionais que não possuem formação adequada. Não havendo formação suficiente de professores de Ciências Naturais os demais cursos que habilitam outros profissionais a atuarem nesse campo devem se adequar à realidade da disciplina numa perspectiva integradora e ampla que permita uma abordagem interdisciplinar dos conteúdos de Ciências.

Marques e Caluzi (2003) defendem o papel crucial do professor frente ao processo de ensino-aprendizagem, mas criticam a incapacidade de muitos professores para cumprir com tal responsabilidade. Além da presença de profissionais de outras áreas do conhecimento atuando como professores de Ciências, conforme já citamos, são mencionadas por Marques e Caluzi (2003) falhas na formação inicial dos professores da área. Esse fato tem gerado o uso inadequado dos modelos que acaba não possibilitando aos alunos relacioná-los aos fenômenos apresentados. A não correlação com os fenômenos pode tornar tal conceito sem sentido para os alunos, não efetivando uma aprendizagem consistente dos conteúdos. Fourez (2003) complementa dizendo que a formação inicial dos licenciandos tem sido muito mais técnica do que centrada na formação de educadores. Desse modo, os professores têm concluído a graduação com domínio de conteúdo, porém sem habilidade para trabalhar tais conhecimentos de forma adequada com os alunos.

Azevedo et al. (2012), ao discutir a formação inicial de professores, explicita que apesar de o papel do professor ter mudado ao longo do tempo, transitando de professor transmissor do conhecimento a professor pesquisador reflexivo, a formação inicial oferecida permanece sem alterações significativas. Dessa forma, as necessidades atuais do ensino não 
são supridas devido às limitações do processo de formação vigente. Faz-se necessário, portanto, que esse processo seja reformulado com inovações que possam suprir as demandas geradas ao longo dos anos visando uma formação adequada para um ensino de qualidade.

Gomes e Oliveira (2007), ao analisarem o uso de analogias, metáforas, imagens e

modelos, se apoiam nas obras de Bachelard, assim como também Andrade, Zylbersztajn e Ferrari (2002), que esclarecem que não há um posicionamento contra todo e qualquer uso dessas linguagens, porém há uma preocupação e uma crítica consistente quanto ao uso inadequado que, associado às concepções prévias dos alunos, pode gerar ou reforçar concepções não científicas.

Segundo Francisco Junior (2009), as analogias, metáforas e modelos estão ligados à ideia geral de comparação em uma tentativa de explicar o desconhecido a partir do que é conhecido. Porém, esses conceitos se diferem entre si. As analogias realçam, de forma evidente, as similaridades entre os domínios analisados, já as metáforas fazem uma comparação implícita que versa sobre as características que não coincidem entre os domínios. As analogias estão inseridas nos livros didáticos de Ciências e se tornaram ainda mais comuns considerando as inúmeras abstrações presentes nos conteúdos científicos. Ao finalizar seu estudo sobre as analogias presentes nos livros didáticos de Química, Francisco Junior (2009) concluiu que, apesar das analogias serem utilizadas com o objetivo de facilitar o entendimento de algo a alguém, a maior parte delas não favorece a aprendizagem, ao invés disso, promovem a compreensão equivocada do conceito alvo.

Como vemos, o ensino de modelos atômicos é bastante desafiador, principalmente quando esse ainda é visto nas séries finais do Ensino Fundamental.

Por estar atualmente trabalhando com o ensino de Ciências nos anos finais do Ensino Fundamental, sinto-me desfiada a estudar aspectos relacionados a essa temática. Assim, em meu mestrado buscarei, a partir do conhecimento das principais dificuldades enfrentadas por professores e alunos em sala de aula, somar melhorias no ensino-aprendizagem do tema modelos atômicos.

A partir dessas considerações surgiu a pergunta que direcionará essa pesquisa: De que maneira a utilização de modelos e modelagem numa abordagem histórica e experimental pode auxiliar na apropriação do conceito de modelos atômicos por alunos do $9^{\circ}$ ano do Ensino Fundamental?

Como fruto desse trabalho, esperamos que, por intermédio da proposta pedagógica diferenciada de abordagem dos conteúdos, os alunos possam formar concepções atomistas 
aceitáveis cientificamente que possam dar a eles os subsídios necessários para a aquisição de conhecimentos posteriores. Nesse sentido, esta proposta de trabalho tem como objetivo:

- Verificar a abordagem dos conceitos de átomo nos livros didáticos de Ciências do $9^{\circ}$ ano do Ensino Fundamental aprovados pelo Programa Nacional do Livro Didático/2014;

- Elaborar, implementar e analisar uma proposição didática para investigar o processo de ensino-aprendizagem dos conceitos de átomo a partir da inserção de estratégias diferenciadas, como aulas dialógicas, experimentação e construção de modelos, diferentes daquelas propostas nos livros didáticos;

- Investigar como a abordagem da construção histórica dos conceitos químicos pode colaborar para que os alunos desmistifiquem o caráter acabado e imutável das descobertas científicas.

Para tal, apresentaremos essa dissertação de mestrado com um capítulo inicial, no qual comentaremos sobre o ensino de Ciências no Ensino Fundamental e sobre as concepções atomistas dos estudantes da Educação Básica. Em seguida, elaboramos um segundo capítulo que aborda as recomendações dos Parâmetros Curriculares Nacionais ao ensino dos modelos atômicos. No terceiro capítulo abordaremos como os modelos atômicos estão sugeridos nas Orientações Curriculares do DF. No quarto capítulo explanaremos sobre o Programa Nacional do Livro Didático e sobre a seleção dos livros de Ciências. Depois, no quinto capítulo, abordaremos os conceitos de modelo e modelagem e as contribuições desses para o ensino de Ciências. No sexto capítulo comentaremos sobre o papel da experimentação no ensino de Ciências. Em seguida, no sétimo capítulo, exibiremos a metodologia utilizada nesta pesquisa. Depois, apresentaremos no oitavo capítulo os resultados e análises da verificação dos livros didáticos aprovados pelo PNLD/2014 e da implementação da proposição em sala de aula. E no último capítulo apresentaremos algumas considerações acerca do trabalho e de suas contribuições para o ensino. Na sequência, passaremos ao referencial teórico. 


\section{O ENSINO DE CIÊNCIAS NO ENSINO FUNDAMENTAL}

Neste primeiro capítulo optamos por abordar as razões pelas quais se deve ensinar Ciências no nível fundamental da Educação Básica baseados nos argumentos de autores como Fumagalli (1998), Malafaia e Rodrigues (2008) e Silva e Queluz (2003), que justificam com base em argumentos históricos e sociais a abordagem de conteúdos científicos desde os anos iniciais do Ensino Fundamental. Acreditamos que antes de abordar o como ensinar é importante entender o porquê ensinar.

Em seguida, tendo como eixo norteador a obra de Bachelard (1996), comentaremos sobre os obstáculos epistemológicos que têm influenciado no ensino de Ciências. Acreditamos que o reconhecimento de obstáculos ao ensino ajuda a compreender porque o ensino não tem alcançado os resultados almejados.

No último tópico deste capítulo buscamos por meio das referências de Mortimer (1995), Pozo e Crespo (2009) e França, Marcondes e do Carmo (2009) fazer um apanhado das principais concepções atomistas detectadas entre os estudantes da Educação Básica, principalmente entre alunos do Ensino Fundamental, a fim de reconhecer tais concepções na busca por estratégias que possam superá-las.

\subsection{Porque Ensinar Ciências no Ensino Fundamental}

As Ciências Naturais são hoje parte do currículo para a Educação Básica em todo o Brasil. As disciplinas voltadas ao ensino desse conhecimento estão consolidadas na educação formal e seria um tanto quanto anacrônico, em tempos atuais, questionar a inserção de conteúdos científicos no nível fundamental da educação. Mas, a Ciência nem sempre esteve presente no currículo escolar. Segundo Silva e Queluz (2003), a inserção desse conhecimento como disciplina na Educação Básica está atribuída a um contexto histórico social que envolve as influências do capitalismo e a supervalorização da Ciência e da Tecnologia.

No período entre os séculos XVIII e XIX a Revolução Francesa e a Revolução Industrial redimensionaram o papel social da Ciência, que passou a tomar novos 
direcionamentos, visando atender as exigências da globalização industrial. Já no século XX, impulsionadas pelo capitalismo, a Ciência e a Tecnologia se desenvolveram em escala altíssima e para que as necessidades científicas e tecnológicas desse contexto social fossem supridas a Ciência foi incorporada como disciplina no currículo para a Educação Básica (SILVA e QUELUZ, 2003).

Além das influências do sistema capitalista, pesquisadores elencam várias outras razões plausíveis que justificam a inclusão do conhecimento científico como disciplina desde os anos iniciais do Ensino Fundamental. Fumagalli (1998) elenca três motivos que considera básicos: "a) o direito das crianças de aprender ciências; b) o dever social obrigatório da escola fundamental, como sistema escolar, de distribuir conhecimentos científicos ao conjunto da população, e c) o valor social do conhecimento científico" (p. 15).

Segundo o autor, aprender Ciências é colocado como um direito da criança visto que ela é parte integrante da sociedade, deste modo, ela possui o direito de apropriar-se da cultura elaborada socialmente como quaisquer outros membros da sociedade. O conhecimento científico faz parte dessa cultura. Por meio dele o indivíduo se torna mais apto a interpretar e compreender o mundo a sua volta. As crianças possuem uma forma particular de fazer a leitura de mundo, mas não menos importante que a dos demais membros. Deixar de ensinar Ciências nos anos iniciais supondo uma inadequação etária das crianças é uma forma de discriminá-las como sujeitos sociais (MALAFAIA e RODRIGUES, 2008).

Fumagalli (1998) fala também sobre o dever social da escola de difundir conhecimentos científicos. Para o autor, o ensino escolar tem um importante papel social, pois é responsável pela "distribuição social de um corpo de conteúdos culturais socialmente significativos” (p. 16). Ainda que a escola possua caráter assistencial, a distribuição social de conteúdos deve ser objetivo central da instituição, pois os demais grupos sociais não são capazes de assumir tal papel. A escola é o ambiente que possibilita, de forma adequada, o acesso a esses conteúdos (MALAFAIA e RODRIGUES, 2008). Esses conhecimentos, proporcionados pelo ensino escolar, são de grande importância para promover a participação social do indivíduo, seja ele criança, jovem, adulto ou idoso.

Em relação ao valor social do conhecimento científico, citado por Fumagalli (1998), sabemos que todas as pessoas interagem de alguma forma com a realidade a sua volta, independente da apropriação de conhecimentos científicos ou não. Porém, tais conhecimentos possibilitam uma participação ativa e mais crítica do indivíduo em seu meio social. A partir dos conhecimentos científicos é esperado que o cidadão possa tomar decisões mais acertadas 
para o seu bem estar e o bem estar social. Esse conhecimento também tem valor na prática social das crianças, pois as mesmas buscam no conhecimento científico encontrar explicações para os fenômenos a sua volta. Dar respostas aos questionamentos das crianças significa não apenas sanar suas curiosidades, mas valorizar sua prática social hoje e contribuir para a formação de adultos responsáveis e críticos.

Tais aspectos, entre outros, justificam a necessidade do ensino das Ciências Naturais no Ensino Fundamental. Nesse nível de educação o ensino-aprendizagem de conceitos científicos exige adequações que estejam de acordo com a capacidade intelectual de alunos dessa faixa etária e tornem esses conhecimentos mais interessantes.

A Química tem sido inserida na Educação Básica com o objetivo de “ensinar o aluno a compreender, interpretar e analisar o mundo em que vive, suas propriedades e suas transformações...” (POZO e CRESPO, 2009, p. 139). Esta visão contribui com a formação crítica cidadã proposta pelos Parâmetros Curriculares Nacionais (BRASIL, 1998) no qual o aluno, adquirindo conhecimento a respeito do mundo a sua volta, se torna capaz de criticar e tomar decisões conscientes para desempenhar seu papel na sociedade. Valorizando o ensino da Química para alcançar uma participação social esclarecida, Martins et al. (2004) elenca oito princípios que devem nortear o ensino de Química: 1) ensinar Química como um dos pilares da cultura do mundo moderno; 2) ensinar Química para o dia a dia; 3) ensinar Química como forma de interpretar o mundo; 4) ensinar Química para a cidadania; 5) ensinar Química para compreender a sua inter-relação com a tecnologia; 6) ensinar Química para melhorar atitudes face a essa Ciência; 7) ensinar Química por razões estéticas e; 8) ensinar Química para preparar escolhas profissionais. Entendemos que esses princípios podem ser considerados também no ensino de Ciências, já que a Química, além de compor essa disciplina, está diretamente associada aos demais conteúdos que devem ser abordados de maneira interdisciplinar, o que também é referendado por Milaré e Alves Filho (2010).

\subsection{Obstáculos ao Ensino de Ciências}

Além das dificuldades já apresentadas em relação ao ensino de Ciências, Gomes e Oliveira (2007) fazem referência em sua pesquisa a vários obstáculos relacionados ao ensino de modelos atômicos, descritos anteriormente por Bachelard (1996). O primeiro obstáculo a 
que o texto se refere é o obstáculo epistemológico que é a acomodação do novo conhecimento ao que já se conhece, oferecendo uma satisfação imediata que não resulta na compreensão científica do fenômeno. São exemplos desse obstáculo o que Bachelard (1996) chama de experiência primeira, que é a apreciação do experimento sem relação com a explicação científica, e a generalização, que facilita a compreensão do conteúdo, mas dificulta qualquer forma de aprofundamento. Outro obstáculo proposto é o substancialista, que se caracteriza pela atribuição de qualidades aos fenômenos. Os autores fazem referência ainda ao obstáculo epistemológico animista, que é a atribuição de vida a determinado fenômeno. Tais obstáculos surgem da tentativa frustrada de facilitar a compreensão do conteúdo para o aluno. Ao invés de auxiliar, os métodos utilizados proporcionam a aprendizagem de conceitos distintos dos aceitáveis cientificamente.

Os problemas detectados são ainda maiores quando a complexidade do conteúdo está acima da capacidade de compreensão do público alvo. Quanto à abordagem dos conteúdos da Química no Ensino Fundamental, os Parâmetros Curriculares Nacionais - PCN (1998) indicam que sejam realizadas sem aprofundamento no nível molecular, julgando ser uma abordagem desse nível de abstração precoce para alunos dessa facha etária:

[...] deve ser evitado pelo professor detalhar o que acontece no nível molecular e atômico, o que ainda faz pouco ou nenhum sentido neste nível da escolaridade, conforme tem se evidenciado na pesquisa acadêmica e na prática em sala de aula (BRASIL, 1998, p. 98).

Ainda assim, o que se faz presente no atual Currículo para a Educação Básica do DF (2010) e que se verifica em muitos livros didáticos do $9^{\circ}$ ano é a apreciação de conteúdos em níveis atômicos, não recomendados pelos PCN (1998).

Há ainda outros aspectos presentes na abordagem dos conteúdos de Química que contrariam as orientações de documentos oficiais. Apesar das inúmeras pesquisas na área educacional ainda se faz presente no ensino de Química o ensino por transmissão em que são favorecidas a atuação passiva dos alunos, a memorização de informações e a aquisição superficial de conhecimentos não contextualizados cobrados posteriormente em testes e provas na forma como foram apresentados (FERNANDES et al., 2012). Segundo Schnetzler e Aragão (1995), há poucos indícios de que propostas de ensino com esse padrão possam visar à compreensão do aluno.

As tecnologias envolvidas nesse processo têm chamado atenção de inúmeros pesquisadores. A Ciência e a Tecnologia estão inseridas e exercem cada vez mais influência 
em nosso dia a dia. As inovações nesse campo são muito rápidas e é preciso acompanhá-las já que nossos alunos estão inseridos em um mundo tecnológico. Krasilchik (2004), ao discorrer sobre um conjunto de modalidades didáticas cabíveis na abordagem dos conteúdos escolares aulas expositivas, discussões, demonstrações, aulas práticas, excursões, simulações, instruções individualizadas e projetos -, pontua que, seja qual for a modalidade adotada pelo professor, essa pode ser complementada por recursos tecnológicos como, por exemplo, DVD, data show, computadores, quadro interativo, entre muitos outros. Os recursos antigos e tradicionais utilizados de forma exclusiva se tornaram inadequados e insuficientes. Esse fato tem contribuído para o surgimento de novas propostas de mudança no ensino. Considerando a dimensão das Ciências e a complexidade de seus conteúdos o professor deve buscar, por meio de novas metodologias, proporcionar um ensino dinâmico e inovador a fim de despertar o interesse e a criatividade dos alunos e favorecer a compreensão dos conteúdos científicos (CORREIA, 2011).

\subsection{Concepções Atomistas dos Estudantes}

Segundo França, Marcondes e do Carmo (2009), as concepções atomistas não aceitáveis cientificamente apresentadas pelos estudantes são fruto desse processo de ensinoaprendizagem inadequado e não adaptado ao nível de conhecimento e potencialidade do aluno. Faz-se necessário um ensino de Química participativo e contextualizado que estimule as habilidades cognitivas dos alunos numa perspectiva de formação crítica cidadã.

Mortimer (1995), em um estudo sobre as concepções alternativas dos estudantes sobre a matéria, descreve três concepções atomistas percebidas entre alunos do $9^{\circ}$ ano do Ensino Fundamental. A primeira detectada por ele é a dificuldade de aceitar a existência de espaços vazios entre as partículas, a segunda é a dificuldade em relacionar os modelos atômicos ao comportamento dos materiais em suas diversas transformações atribuindo propriedades macroscópicas ao átomo, e a terceira é a tendência dos alunos em atribuir como causa do aumento do volume a dilatação das próprias partículas.

Para Pozo e Crespo (2009) a não aceitação de espaços vazios entre as partículas é uma das concepções mais resistentes à mudança conceitual, pois está profundamente enraizada em nossa percepção macroscópica do mundo. Os alunos em muitos casos sugerem o ar como 
preenchimento entre as partículas e negam um vazio em que nada existe em absoluto, pois é contrário à razão. Como exemplo da concepção que atribui o aumento do volume à dilatação das próprias partículas esses autores citam que os estudantes “... diante da dilatação de uma barra de ferro, vão assumir que as partículas do ferro aumentam de tamanho...” (p. 153). Acrescentam ainda que há uma dificuldade também em compreender o movimento contínuo e intrínseco das partículas, pois no mundo como nós o percebemos a matéria está em repouso.

França, Marcondes e do Carmo (2009) detectaram outras várias concepções, desta vez entre alunos do Ensino Médio. Os estudos apontaram que os alunos apresentam dificuldade em compreender a estrutura da matéria e muitos utilizam de argumentos macroscópicos para explicá-la; demonstram também dificuldade em aceitar o caráter descontínuo da matéria, concordando com a concepção acima detectada por Mortimer (1995); julgam ser o átomo a menor parte constituinte da matéria e outras vezes até mesmo a célula; associam predominantemente o átomo ao modelo de orbital em que as órbitas seriam entidades independentes; muitos aceitam que os elétrons não podem ser separados do átomo e; atribuem caráter indivisível ao átomo.

Como vemos, o ensino de modelos atômicos não tem alcançado os resultados almejados provavelmente devido às inadequações na abordagem dos conteúdos relacionados a esse tema. Consideramos de extrema relevância conhecer como os documentos oficiais orientam tal abordagem a fim de verificar a compatibilidade desses com o proceder das instituições educacionais. Para tanto, comentaremos no próximo capítulo sobre as recomendações dos Parâmetros Curriculares Nacionais ao ensino de modelos atômicos. 


\section{O ENSINO DE MODELOS ATÔMICOS E OS PARÂMETROS CURRICULARES NACIONAIS}

Neste segundo capítulo optamos por buscar nos Parâmetros Curriculares Nacionais (BRASIL, 1998) orientações quanto ao ensino dos modelos atômicos. Por meio dessa pesquisa buscamos comparar as orientações desse documento e a realidade da abordagem desse conteúdo no Ensino Fundamental a fim de verificar as conformidades e as discrepâncias entre documentos oficiais e a realidade escolar.

\subsection{Os Modelos Atômicos nos Parâmetros Curriculares Nacionais}

Os Parâmetros Curriculares Nacionais de Ciências Naturais (BRASIL, 1998) é um documento elaborado a fim de orientar o trabalho de educadores. São apresentados objetivos comuns a todas as áreas do Ensino Fundamental e objetivos específicos para as Ciências Naturais. Entre os objetivos comuns a todas as áreas encontra-se forte menção à formação cidadã, com a qual a Ciência, capaz de ampliar a participação social e o desenvolvimento mental de quem a estuda, pode contribuir.

Os objetivos gerais da área de Ciências são coerentes com os objetivos colocados para o Ensino Fundamental e visam que o aluno desenvolva a capacidade de atuar como cidadão utilizando conhecimentos de caráter científico e tecnológico. Então, o ensino de Ciências deve promover o conhecimento científico auxiliando na formação do cidadão crítico e participativo.

Os objetivos específicos para o quarto ciclo, que se compõe pelos atuais $8^{\circ}$ e $9^{\circ}$ anos, foram elaborados para que ao final do mesmo o aluno adquira capacidade de compreender as relações entre o processo social e a evolução das tecnologias, confrontar as diferentes explicações individuais e coletivas, reconhecendo a existência de diferentes modelos explicativos na Ciência, compreender a história evolutiva dos seres vivos e caracterizar as transformações tanto naturais como induzidas pelas atividades humanas, na atmosfera, na litosfera, na hidrosfera e na biosfera, entre outras. Tais objetivos podem ser vistos como 
direcionamentos para a escolha dos conteúdos considerando que esses devem ser selecionados visando alcançar os objetivos propostos e também atender as individualidades de cada instituição escolar.

Os critérios estabelecidos pelos PCN para a escolha dos conteúdos ressaltam que esses devem favorecer a construção de uma visão de mundo pelo estudante, promover as relações entre diferentes fenômenos da natureza e objetos tecnológicos, devem ser relevantes de um ponto de vista social, cultural e científico e devem ser promovidos de forma compatível com as possibilidades e necessidades de aprendizagem do estudante.

Os conteúdos específicos escolhidos de acordo com os critérios mencionados acima são colocados pelos PCN como sugestão ao professor, que deve, ao selecioná-los, fazer uma abordagem compatível com a realidade local, assim como determinar quais temas deverão ser abordados com mais profundidade.

Ainda embasados nos critérios de seleção para os conteúdos, foram estabelecidos quatro eixos temáticos para o quarto ciclo do Ensino Fundamental que induzem a uma abordagem interdisciplinar dos vastos conteúdos de Ciências, conforme é recomendado pelos próprios PCN. São os eixos: Vida e Ambiente, Ser Humano e Saúde, Tecnologia e Sociedade e Terra e Universo.

Os eixos temáticos são uma organização dos conceitos, procedimentos, atitudes e valores para cada ciclo. Ao apresentar de forma ampla os conceitos a serem abordados em cada eixo não se pode observar, em momento algum, citação do conceito de átomo ou de questões direcionadas a esse conteúdo para essa faixa etária.

Em seguida, os conceitos sugeridos para serem abordados em cada eixo são esmiuçados e direcionados especificamente para o terceiro ou quarto ciclo. Em todos os eixos a forma como os conteúdos são citados induzem a abordagem interdisciplinar dos mesmos. Porém, apenas no eixo Vida e Ambiente o conteúdo de Química é abordado de forma mais concreta. Esse eixo propõe que ao final do quarto ciclo o aluno tenha condições de compreender os fenômenos químicos e bioquímicos e relacionar alguns fenômenos aos ciclos biogeoquímicos. Para isso, sugere-se que o professor trabalhe com os alunos as substâncias e suas propriedades, misturas e reações químicas, devendo o aluno compreender ainda, segundo o documento, que a matéria é constituída por partículas e que essas são constituídas por átomos. Ainda assim, o professor deve evitar detalhar o que acontece no nível molecular e atômico, pois isso ainda faz pouco ou nenhum sentido para o aluno neste nível de escolaridade. 
Como podemos observar, os PCN, cumprindo sua função de estabelecer parâmetros e atribuindo à instituição escolar e ao professor o papel e autonomia para selecionar os conteúdos a serem abordados ao longo do ano, sugere que os conceitos atômicos não devem ser abordados nesse nível de escolaridade. Porém,os conceitos de átomo estão presentes em vários livros aprovados pelo Programa Nacional do Livro Didático/2014 para o $9^{\circ}$ ano, como veremos mais a frente.

Apesar das recomendações dos PCN constatamos que os conteúdos atômicos são, quase sempre, abordados no $9^{\circ}$ ano do Ensino Fundamental. Em uma pesquisa realizada com nove professores de Ciências do $9^{\circ}$ ano, Milaré e Alves Filho (2010) verificaram que dentre eles oito abordam os modelos atômicos nessa série escolar.

Estando esse conceito presente na realidade do ensino escolar, concordamos que a inserção de novas estratégias de ensino, que minimizem as dificuldades no processo de ensino-aprendizagem dos conteúdos relacionados ao átomo, pode favorecer a formação de concepções atomistas aceitas cientificamente pelos alunos. Metodologias diferenciadas que favoreçam a participação do aluno como agente ativo no processo de aquisição do conhecimento precisam ser priorizadas em detrimento das metodologias tradicionais que não têm alcançado os objetivos de ensino propostos.

Após a verificação dos PCN, daremos continuidade à análise de documentos oficiais visando recomendações à abordagem dos modelos atômicos no $9^{\circ}$ ano do Ensino Fundamental. Para tanto, examinaremos, no próximo capítulo, as Orientações Curriculares do DF considerando a relevância deste documento para a elaboração do Plano de Ensino Anual, que define os conteúdos que serão abordados ao longo do ano. 


\section{O ENSINO DE MODELOS ATÔMICOS E AS ORIENTAÇÕES CURRICULARES}

Neste capítulo daremos continuidade às buscas por conexões entre as orientações de documentos oficiais e a realidade escolar no que se refere ao ensino dos modelos atômicos. Aqui faremos uma busca nos dois últimos Currículos da Educação Básica do Distrito Federal (2000 e 2010) para comparar as conformidades desses com a prática das instituições de ensino.

\subsection{Os Modelos Atômicos nas Orientações Curriculares}

O Currículo da Educação Básica do DF foi elaborado para auxiliar a prática pedagógica dos educadores como um instrumento de apoio visando à boa qualidade no ensino. Nele são citados conteúdos relevantes a serem trabalhados ao longo de cada ano letivo. Assim como os PCN, o Currículo tem como finalidade a formação para a cidadania.

Aqui será feita uma análise dos dois últimos Currículos da Educação Básica do DF, publicados nos anos 2000 e 2010, com foco no tema modelos atômicos. Na versão publicada em 2000 são listadas as competências, habilidades e procedimentos que devem ser adotados em cada componente curricular e em cada série do Ensino Fundamental. Nas Ciências Naturais, mais especificamente na $8^{\mathrm{a}}$ série (conforme citado no Currículo de 2000 e atual $9^{\circ}$ ano), é sugerido que o aluno adquira habilidade de "Reconstruir, historicamente, os modelos atômicos até o atual e mostrar que estes evoluíram com o avanço tecnológico.” (DISTRITO FEDERAL, 2000, p. 257).

No Currículo publicado em 2010, versão atual, são expressas as habilidades que se espera que o aluno adquira e a lista de conteúdos sugeridos para o alcance dessas habilidades. Para alcançar a habilidade de "Conhecer os modelos atômicos, a evolução das teorias e suas contribuições para o avanço tecnológico.” (DISTRITO FEDERAL, 2010, p. 165) é proposto o conteúdo átomos: conceito, modelo atômico, íons e avanço tecnológico. 
Apesar do currículo de 2000 não fazer sugestões de conteúdos, fíca implícito a necessidade da abordagem dos conteúdos sugeridos pelo currículo de 2010 para o alcance das habilidades propostas. Percebemos assim, que há uma discrepância entre a proposta de conteúdos dos PCN e a proposta das Orientações Curriculares do DF. Enquanto os PCN sugerem uma abordagem não aprofundada no nível molecular e atômico para o $9^{\circ}$ ano do Ensino Fundamental, o Currículo sugere competências a serem alcançadas que exigem a abordagem mais detalhada de conceitos e estruturas atômicas.

Possivelmente a presença do conteúdo de modelos atômicos em parte dos livros aprovados pelo Programa Nacional do Livro Didático/2014 se deve a essa divergência de orientações (PCN/Orientações Curriculares). Faremos a seguir algumas considerações sobre o Programa Nacional do Livro Didático e sobre a seleção dos livros didáticos de Ciências da rede pública de ensino. 


\section{O PROGRAMA NACIONAL DO LIVRO DIDÁTICO}

Neste quarto capítulo buscamos fazer uma síntese do que vem a ser o Programa Nacional do Livro Didático, abordamos sobre sua função e contribuições para a seleção dos livros. Comentamos ainda sobre o Guia de Livros Didáticos, produto desse programa, e suas contribuições para a escolha dos livros didáticos de Ciências.

Abordamos ainda aspectos da seleção dos livros para 2014. Acreditamos que o conhecimento do processo seletivo dos livros didáticos tem importante relevância considerando que esses estão presentes e influenciam diretamente no processo de ensinoaprendizagem.

\subsection{Contribuições do Programa Nacional do Livro Didático para a Seleção dos Livros Didáticos}

O Programa Nacional do Livro Didático (PNLD) em seu âmbito atual tem a função de, além de distribuir, analisar a qualidade dos livros didáticos oferecidos para toda a Educação Básica em nível nacional, a fim de subsidiar o trabalho pedagógico dos professores. Essa necessidade surgiu a partir de um estudo realizado pelo Ministério da Educação (MEC) em que foi detectado que os livros mais solicitados pelos professores e que estavam sendo distribuídos para as escolas apresentavam erros conceituais e informações desatualizadas. Esse fato fez com que o programa sofresse significativas mudanças a partir de 1996. O governo que, até então, tinha a função de comprar e distribuir os livros didáticos passa a assumir a responsabilidade de avaliá-los antes que sejam ofertados. A avaliação é feita em ciclos trienais por uma comissão de agentes educacionais selecionada pelo próprio programa. A avaliação resulta no Guia de Livros Didáticos que são distribuídos para todas as escolas para que os professores tenham acesso e estão disponíveis na web.

Considerando que a seleção do livro didático deve ser cuidadosa, os Guias são fornecidos para dar subsídios para uma boa escolha. Eles divulgam os resultados da análise dos livros didáticos por meio de resenhas que se iniciam com uma descrição do sumário da 
obra para que o professor tenha conhecimento dos conteúdos abordados e em seguida uma síntese avaliativa que expressa as características gerais do livro com base em critérios avaliativos pré-determinados que são adaptados a cada edição. $\mathrm{Na}$ edição de 2014 cinco critérios nortearam as avaliações. São eles: Proposta pedagógica, Conteúdo, Ciência, Pesquisa e experimentação, Manual do professor e Projeto editorial.

\subsection{Seleção dos Livros Didáticos de Ciências}

Com base no que afirmam Echeverría, Mello e Gauche (2011), um número significativo de professores não tem condições de avaliar os livros didáticos, ou porque são profissionais de outras áreas, sem qualificação para o ensino, ou porque não o fizeram ao longo da formação inicial. Desse modo, ao invés de escolherem baseados em um exame minucioso, fazem a escolha induzidos por aspectos atrativos não criteriosos. Os Guias tornam-se assim importantíssimos para orientar uma escolha mais criteriosa do livro didático.

O documento deixa explícito que o programa avalia os livros com base em critérios gerais, mas que o professor deve escolher aquele que melhor se adequa aos seus objetivos e usar de sua autonomia para mudar e/ou complementar a ordem dos conteúdos e a forma como os mesmos são abordados no livro sempre que julgar necessário. Relembra também que o livro didático deve ser usado como um instrumento de apoio e estar associado a outros recursos e outros meios de informação estimulando outras leituras, conforme defendem Echeverría, Mello e Gauche (2011) em razão da sofisticação dos artefatos educacionais disponíveis.

Um dos critérios de avaliação dos livros é a Abordagem do Conteúdo, que analisa o caráter científico e atual dos conteúdos de cada coleção e o tratamento dado a temas interdisciplinares e do cotidiano dos alunos. Não foi feita em nenhum momento referência a algum critério que avalie a coerência da inclusão ou não dos conteúdos nos livros. A análise gira em torno da forma como eles são abordados, e não se devem ou não ser abordados.

Os livros aprovados pelo PNLD/2014 para Ciências foram: Ciências; Ciências Naturais; Ciências Naturais - Aprendendo com o cotidiano; Ciências, Natureza \& Cotidiano; Ciências no século XXI; Ciências nos dias de hoje; Ciências novo pensar - edição renovada; Ciências para nosso tempo; Companhia das Ciências; Jornadas.CIE - Ciências; Ciências da 
natureza; Observatório de Ciências; Oficina do saber Ciências; Para viver juntos - Ciências; Perspectiva - Ciências; Projeto Araribá - Ciências; Projeto Radix - Ciências; Projeto Teláris - Ciências; Projeto Velear - Ciências e; Vontade de saber Ciências.

Agora que já foram abordadas questões referentes aos problemas enfrentados no ensino de Ciências, principalmente no que diz respeito ao tema modelos atômicos, às recomendações de documentos oficiais para o ensino dos conteúdos referentes a esse tema e ao processo de escolha dos livros didáticos, ferramenta muito acessada por professores e alunos, comentaremos sobre estratégias de ensino que podem ser utilizadas como meio facilitador no processo de ensino-aprendizagem do tema modelos atômicos, a começar pelo uso de modelos e modelagem no ensino de Ciências. 


\section{O USO DE MODELOS NO ENSINO DE CIÊNCIAS}

Neste capítulo optamos por abordar os conceitos de modelo e modelagem considerando que antes que sejam introduzidos na proposta de ensino é importante atribuir um significado comum a esses termos.

Em seguida, baseados em autores como Justi (2011) e Ferreira (2006) comentaremos sobre as contribuições dessa ferramenta para o ensino de Ciências, assim como suas possibilidades no processo de ensino-aprendizagem.

\subsection{Conceituando Modelo e Modelagem}

Ensinar conteúdos químicos na Educação Básica é desafiador, principalmente quando a maior parte desses possui uma complexidade inerente que se justifica pelo alto nível de abstração dos conceitos abordados. As dificuldades de aprendizado dessa Ciência demandam a inserção de metodologias e recursos que superem tais barreiras. $\mathrm{O}$ uso de modelos no ensino dos conteúdos químicos é uma das possibilidades que, se utilizada de maneira adequada, pode gerar resultados positivos no que se refere à compreensão de conceitos científicos.

Os modelos aparecem no processo de ensino-aprendizagem como uma ferramenta facilitadora para ensinar Ciências. Mas, antes de abordarmos sua abrangência no ensino discutiremos a respeito do seu conceito.

Conforme já apresentamos na página 18, para Ferreira e Justi (2008) um modelo pode ser definido como:

[...] uma representação parcial de um objeto, evento, processo ou ideia, que é produzida com propósitos específicos como, por exemplo, facilitar a visualização; fundamentar elaboração e teste de novas ideias; e possibilitar a elaboração de explicações e previsões sobre comportamentos e propriedades do sistema modelado (FERREIRA e JUSTI, 2008, p. 32).

Justi (2011) aborda uma definição um pouco mais concisa e completa em que um modelo pode ser definido como “... uma representação parcial de uma entidade, elaborado 
com um, ou mais, objetivo(s) específico(s) e que pode ser modificado.” (p. 211) e ressalta alguns importantes aspectos dessa definição: $1^{\circ}$ ) dizer que modelo é uma representação parcial de uma entidade significa dizer que ele não é uma cópia da realidade. Representar se difere de reproduzir, não implica necessariamente em semelhança entre o modelo e o modelado e devido a essas diferenças o modelo incorpora algumas restrições; $2^{\circ}$ ) é comum que seja remetido à palavra modelo a ideia de objeto, mas é importante considerar que os modelos podem representar aspectos visíveis e não visíveis, como ideias, eventos ou processos; $3^{\circ}$ ) o fato do modelo ser elaborado significa que ele tem natureza humana, foi construído, não se encontra disponível na natureza; $4^{\circ}$ ) possui diferentes objetivos dependendo da entidade que é modelada e do público alvo para o qual o modelo foi construído. Na circunstância da entidade modelada ser o átomo e o público alvo ser alunos do Ensino Fundamental pode-se considerar o objetivo de "facilitar a visualização de entidades abstratas" (p. 212), por exemplo, e; $5^{\circ}$ ) o modelo não é absoluto. Ele pode ser modificado se o nosso conhecimento sobre a realidade for alterado, se as explicações e/ou previsões feitas a partir dele forem percebidas como inadequadas e se novas formas de representação forem disponibilizadas.

Modelagem é a atividade de elaborar, expressar, testar e reformular modelos (JUSTI, 2011). Ela permite que o aluno perceba a complexidade e as limitações do processo de construção dos conhecimentos científicos, uma realidade cheia de incertezas e dúvidas, diferente do que é apresentado na escola. No geral, não há regras para a construção dos modelos como há para outros procedimentos científicos, porém, existem etapas inerentes a esse processo. Justi (2011) considera que são quatro as etapas necessárias e que cada uma delas influencia diretamente nas outras, como ela mesma representa na figura 1. 


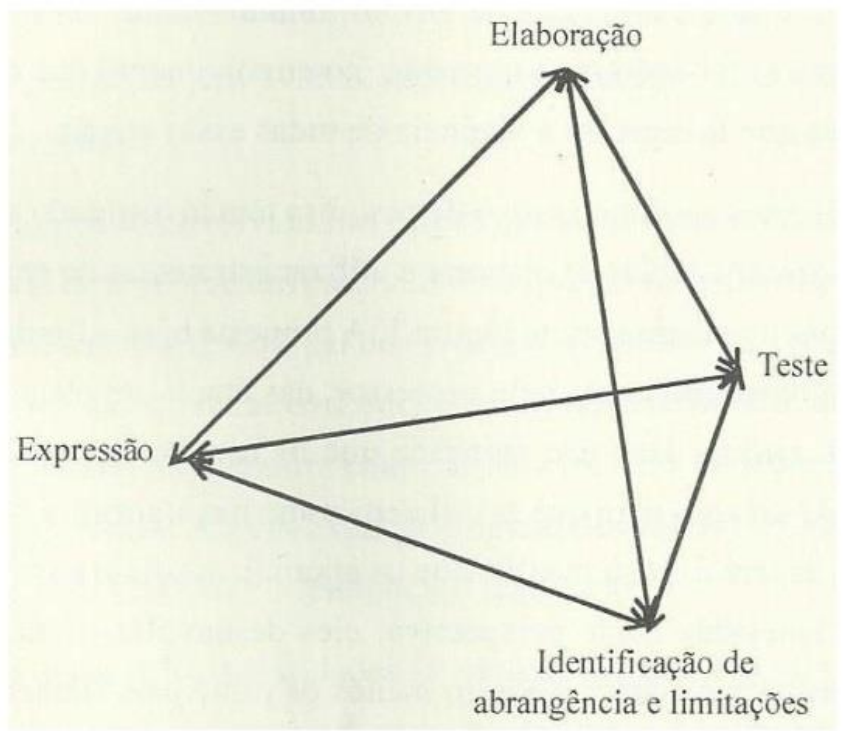

Figura 1: Relacionamento entre as principais etapas envolvidas na modelagem. Fonte: Justi, 2010 Apud Justi, $2011^{1}$.

O ser humano tem em si uma necessidade inerente de criar modelos para ajudá-lo a entender o universo que o cerca (QUINTO e FERRACIOLI, 2008). Ele constrói um modelo mental e a partir da manipulação dele tenta prever e/ou explicar eventos do mundo físico. Dessa forma os modelos estão sempre presente no processo de aquisição e construção do conhecimento.

Apesar de não haver uma definição geral, Greca (2011) adota uma visão de modelo mental como sendo:

[...] uma representação interna que atua como um análogo estrutural de situações ou processos. Sua função é a de dar conta dos raciocínios dos indivíduos tanto quando tentam compreender o discurso como quando procuram explicar ou predizer o comportamento do mundo físico (GRECA, 2011, p. 395).

O modelo mental é então uma representação interna, pessoal, que para ser compartilhado precisa ser expresso. A esse modelo, acessível a outros indivíduos de modo concreto, verbal, matemático, visual ou gestual, é atribuído o nome de modelo expresso. Quando um grupo social concorda sobre um modelo expresso esse modelo é denominado modelo consensual. Se o grupo social for o de cientistas e se o modelo for usado para fins de

\footnotetext{
${ }^{1}$ JUSTI, R. Las concepciones de modelos de los alumnos y el aprendizaje de las ciencias. Una relación compleja y central en la enseñanza de las ciencias. In: CAAMAO, A. (Ed.). Didáctica de la fisica y química. Barcelona: Editorial Graó, 2010. Apud Justi (2011).
} 
desenvolvimento do conhecimento científico atribui-se a ele o nome de modelo científico. E ainda, se esse modelo foi aceito em um contexto que não o atual ele pode ser chamado de modelo histórico (JUSTI, 2011).

Os modelos estão sendo frequentemente usados no ensino de Ciências e nesse meio também são classificados de acordo com sua funcionalidade. Como os modelos científicos são muito complexos são feitas representações simplificadas deles, chamadas de modelos curriculares. Esses modelos, apesar de também serem utilizados nas aulas de Ciências se diferem dos modelos de ensino porque estes são criados especificamente para auxiliar os estudantes a compreenderem algum aspecto que o professor deseja ensinar (JUSTI, 2011).

\subsection{Contribuições dos Modelos/Modelagem para o Ensino de Ciências}

Apesar do auxílio dos modelos para a compreensão de conceitos abstratos, existem críticas relevantes em relação à sua utilização em sala de aula. Segundo Justi (2011), muitos professores e futuros professores lidam com modelos como sendo cópias da realidade, além de utilizá-los sem atribuir a devida relevância a seu processo de elaboração e apresentá-los como verdade para os alunos. Ferreira (2006) aponta, além dessas, outras duas dificuldades na utilização dos modelos para o ensino. Segundo a autora, não é usual que os estudantes sejam convidados a participarem ativamente do processo de construção dos modelos e os livros didáticos os apresentam sem dar qualquer explicação e/ou discussão sobre essa estrutura.

Justi (2011) também discute as causas pelas quais o uso dos modelos tem falhado. Ela aponta quatro razões principais para esse fato: a) os modelos têm sido apresentados de maneira que os fazem parecerem fatos, tanto para alunos como para professores, b) tal abordagem está dando suporte ao estabelecimento de modelos híbridos, c) o uso equivocado de elementos gráficos tem introduzindo aspectos incorretos em alguns modelos e d) os modelos não são acompanhados de discussões de suas limitações. Desse modo o objetivo da utilização de modelos fica limitado e, além disso, essa forma de abordagem pode proporcionar a aprendizagem de conceitos errôneos pelos estudantes.

Ferreira (2006), ao investigar o uso de modelos no ensino, expõem algumas concepções a respeito dessa estrutura pelos alunos. Ela aponta que os estudantes têm 
dificuldade de definir o que é um modelo, que acreditam que só há modelos do que é visível e os concebem como cópias ou miniaturas da realidade.

Se tratando especificamente dos modelos atômicos, Justi (2011) constatou que a maioria dos estudantes pensa que o átomo é o que está desenhado nos livros, que estes são ampliações da realidade e que o modelo mais recente é perfeito.

Mas, os modelos, se utilizados de forma adequada, podem promover a aprendizagem consistente de conceitos científicos. O uso dos modelos no ensino ajuda a promover um ensino em que a Ciência faça sentido para o aluno, de modo que esse conhecimento possa ser aplicado em diferentes contextos. Ele envolve o aluno no processo de apropriação do conhecimento.

Ferreira (2006) defende que, por menor que seja a dimensão, educadores têm abandonado a didática tradicional e inserido novas propostas de ensino em seu planejamento. O uso de modelos e modelagem é uma delas. Ele promove um aprendizado participativo e colaborativo na construção de significados, conceitos e representações e permite que o aluno aprenda sobre os processos de construção da Ciência. Permite a visualização de conceitos abstratos por meio de estruturas que ele pode explorar e o desenvolvimento de conhecimentos mais flexíveis e abrangentes.

Justi (2011), após desenvolver inúmeras pesquisas baseadas na utilização de modelos e modelagem seguindo as etapas representadas na Figura 1, concluiu que a maior parte dos estudantes das turmas investigadas aprende o conteúdo envolvido nas estratégias de ensino de forma significativa, desenvolve habilidades investigativas relacionadas ao processo de modelagem e desenvolve capacidade de visualização do abstrato nos modelos.

Visto isso, percebemos que os modelos podem facilitar a aprendizagem do conceito de átomo atuando como uma ponte entre teoria e realidade, desde que sejam consideradas tanto as abrangências como as limitações inerentes a essa estratégia.

Além dos modelos, abordaremos também sobre a experimentação como ferramenta facilitadora para o ensino de Ciências. No próximo capítulo comentaremos sobre suas definições assim como suas possibilidades no processo de ensino-aprendizagem. 


\section{O PAPEL DA EXPERIMENTAÇÃO NO ENSINO DE CIÊNCIAS}

Neste capítulo abordaremos o papel da experimentação no ensino de Ciências. Buscamos nas referências de Hodson (1994), Gioppo, Scheffer e Neves (1998), Silva, Machado e Tunes (2011), Silva e Zanon (2000) e outros um conceito que pudesse definir a atividade experimental para que a partir desse significado possamos considerar suas contribuições para o ensino visando à inserção dessa no processo de ensino-aprendizagem dos conteúdos científicos.

\subsection{Contribuições da Atividade Experimental para o Ensino de Ciências}

Não é incomum nas pesquisas educacionais em meio às novas propostas de ensino encontrar sugestões para que a escola substitua os métodos tradicionais por metodologias que insiram o aluno como agente ativo no processo de apropriação do conhecimento por meio de atividades experimentais. Concordamos que a inserção desses métodos pode trazer muitos benefícios ao processo de ensino-aprendizagem, porém é importante compreender o que vem a ser uma atividade experimental e qual é o seu papel no ensino de Ciências.

A atividade experimental ainda se confunde com o experimento desenvolvido em laboratório, em que se utilizam vidrarias, reagentes químicos e se segue um roteiro. Segundo Hodson (1994), essa atividade experimental, concebida como experimento laboratorial, é aprovada por grupos de professores que as utilizam com diferentes objetivos, que ele agrupa em cinco categorias: 1) para motivar os alunos; 2) para ensinar técnicas de laboratório; 3) para intensificar a aprendizagem de conhecimentos científicos; 4) para proporcionar conhecimento sobre os métodos científicos e; 5) para desenvolver atitudes científicas, como a consideração de ideias e sugestões de outras pessoas, a objetividade e o cuidado para não emitir informações precipitadas.

Tais objetivos são comprovadamente equivocados. Segundo Hodson (1994), nem todos os estudantes desfrutam de igual modo do trabalho de laboratório, o entusiasmo diminui com o passar do tempo e há ainda uma importante minoria que expressa aversão aos trabalhos 
práticos, atenuando $\mathrm{o}$ aspecto motivacional do experimento. $\mathrm{O}$ ensino de técnicas laboratoriais, proposto no segundo objetivo, pode ter duas finalidades, a aquisição de habilidades gerais, transferíveis a outras áreas do conhecimento e válidas para enfrentar problemas cotidianos ou a aquisição de técnicas consideradas básicas para futuros cientistas. $\mathrm{O}$ autor considera esse último argumento eticamente duvidoso e muito ambicioso e o primeiro próximo do que ele considera absurdo, invalidando o segundo objetivo.

Quanto ao terceiro objetivo, Hodson (1994) defende que não se pode afirmar que o trabalho prático é superior a outros métodos e ressalta ainda que em algumas ocasiões parece ser até menos eficaz. O quarto objetivo se desvale quando, conforme o autor, os métodos são empregados para testar a validade das teorias, gerando uma compreensão distorcida da metodologia científica. E quanto ao quinto objetivo o autor afirma que o esforço dos alunos em dar respostas corretas aos questionamentos e a preocupação com o que deve acontecer no experimento, fortemente arraigados nas práticas de laboratório, diminuem as possibilidades de desenvolvimento das atitudes científicas. Ainda assim, professores continuam utilizando as atividades experimentais concebendo que tais práticas ajudarão por si só a alcançar todos os objetivos de aprendizagem.

Além de serem utilizados com o intuito de alcançar objetivos inviáveis, os experimentos laboratoriais recebem ainda críticas quanto à forma como têm sido desenvolvidos. Gioppo, Scheffer e Neves (1998) criticam a preferência dos professores em trabalhar com atividades meramente demonstrativas que se repetem em um ciclo vicioso sem que sejam feitas análises e/ou reflexões do tema estudado. Além do mais, os autores criticam as más condições em que se encontram os laboratórios das escolas, quando esse existe, e o despreparo dos professores para atuarem nesse espaço, gerado por falhas no processo de formação inicial.

Silva e Zanon (2000) mencionam que os professores consideram as atividades experimentais fundamentais para o ensino de Ciências, mas se queixam das condições inadequadas para a realização das práticas, como turmas muito cheias, estrutura precária dos laboratórios e carga horária reduzida. Já as autoras, demonstram maior preocupação com a carência na formação docente. Laboratórios bem equipados, turmas limitadas e um aumento da carga horária de nada adiantam se os professores não tiverem clareza do papel da experimentação no processo de ensino-aprendizagem. As atividades experimentais por si só não asseguram a aprendizagem dos conceitos e nem o estabelecimento de relações entre teoria e prática. 
É lamentável que ainda prevaleça uma visão extremamente simplista das atividades práticas em que a experimentação contribui necessariamente para a aquisição do conhecimento sendo concebida como uma mera manipulação de equipamentos laboratoriais sem que aluno seja nem mesmo capaz de estabelecer relações entre o que está fazendo e o que está aprendendo (SILVA e ZANON, 2000).

A inserção das atividades experimentais no ensino permite relacionar fenômenos e teorias. Um aspecto importante das teorias é a sua capacidade de generalização e previsão, ou seja, quanto maior o número de fenômenos comparáveis que uma teoria consegue explicar, maior é seu grau de generalização e quanto maior o número de fenômenos que ela pode prever, maior seu grau de previsão. Isso significa que quando utilizamos de uma teoria para explicar um fenômeno estamos testando sua capacidade de generalização e previsão (SILVA, MACHADO e TUNES, 2011). De acordo com Giordan (1999), a experimentação pode ser concebida como “... uma espécie de carimbo atestando a força do enunciado geral.” (p. 45).

Apesar disso, a experimentação tem sido utilizada de maneira muito equivocada entre professores. Os experimentos têm sido empregados para tentar provar a veracidade das teorias. Outras vezes, têm sido utilizados como recurso facilitador da aprendizagem, quando se concebe que eles concretizam teorias, porém tal aspecto é de pouca relevância para o aluno, não sendo suficiente para promover a aprendizagem consistente dos conceitos e por fim o aluno não consegue relacionar o fenômeno a teoria (SILVA, MACHADO e TUNES, 2011).

Apesar da utilização de experimentos no ensino de Ciências, esse modelo de ensino continua centrado na transmissão-recepção de conteúdos. É imprescindível que a utilização de atividades experimentais envolva mais reflexão do que a mera repetição de experimentos e a espera dos mesmos resultados incontestáveis. O conhecimento de procedimentos laboratoriais ainda tem sido valorizado em detrimento à reflexão e ao próprio conhecimento dos conceitos científicos (SILVA e ZANON, 2000).

Mas, apesar das críticas, Gioppo, Scheffer e Neves (1998) deixam claro que as atividades de laboratório são imprescindíveis, porém precisam estar acompanhadas de uma metodologia adequada de discussão e análise do fenômeno que está sendo estudado. Além do mais, defendem que o ensino de Ciências no Ensino Fundamental da educação deve ir muito além dos limites do laboratório e das possibilidades que ele permite. Para esses autores o estereótipo de laboratório de Ciências como um local cheio de vidrarias e substâncias que borbulham precisa ser superado. O laboratório de Ensino Fundamental deve ser concebido como um espaço de complementação onde exista um ensino de Ciências interacional. Ter um 
espaço reservado a aulas práticas é, sem dúvidas, muito interessante, no entanto, não pode haver restrições. O laboratório, sozinho, se tornou insuficiente para desenvolver as propostas atuais.

Hodson (1994) também defende a recontextualização das atividades práticas. Segundo ele, a ideia de que tais atividades ajudam a alcançar todos os objetivos está equivocada e, muito pelo contrário, grande parte das práticas oferecidas são confusas e carentes de valor educativo. Ele defende que quaisquer métodos de aprendizagem que exijam dos alunos a postura de agentes ativos ao invés de passivos no processo de ensino-aprendizagem proporcionam uma melhor compreensão dos conteúdos. De acordo como autor entre as atividades que ele considera práticas estão as próprias atividades desenvolvidas em laboratório, atividades que incluem o uso de computadores, estudos de caso, entrevistas, debates, construção de modelos, pesquisas em bibliotecas, produção de fotografias e vídeos.

Silva e Zanon (2000) também apoiam a redefinição do ensino experimental. Segundo as autoras, sua nova estrutura requer uma melhor adaptação das práticas e objetivos claramente expressos, contrários aos inalcançáveis difundidos no meio educacional.

Como vemos, o conceito de atividade experimental ou experimentação tem sido consideravelmente ampliado e alterado nos últimos tempos. Segundo Silva, Machado e Tunes (2011), “A experimentação no ensino pode ser entendida como uma atividade que permite a articulação entre fenômenos e teorias.” (p. 235) e que pode ser realizada em diferentes espaços dentro da própria escola, como a própria sala de aula, o laboratório, a cantina, a horta ou espaços fora da escola, como pracinhas, parques, estabelecimentos comerciais, museus, estações de tratamento de água entre muitas outras opções.

Silva, Machado e Tunes (2011) sugerem algumas modalidades de atividades experimentais que demonstram sua abrangência. Elas englobam atividades demonstrativasinvestigativas, experiências investigativas, simulações em computadores, vídeos e filmes, horta na escola, visitas planejadas e estudos de espaços sociais e resgate de saberes populares. Como vemos, diferentemente do que ainda é concebido por profissionais da área educacional, as atividades experimentais não são experimentos desenvolvidos estritamente em laboratório seguindo roteiros e procedimentos, elas vão muito mais além dos limites da sala de aula e da escola promovendo uma aproximação do aluno com o objeto de estudo.

As atividades acima mencionadas são desenvolvidas em diferentes espaços e podendo ser dada a cada uma delas diferentes ênfases dependendo do conteúdo abordado. Sugere-se, portanto, que tais atividades sejam desenvolvidas de forma interdisciplinar e contextualizada 
em conformidade com documentos oficiais - Parâmetros Curriculares Nacionais e Orientações Curriculares do DF - que ao recomendarem o uso da experimentação no ensino de Ciências incorporam uma abordagem desse porte.

Segundo Chagas (1997), sem o constante diálogo teoria-prática não há Química, o ensino de química exige a valorização dessa inter-relação. Para o autor quem transforma a matéria precisa pensar sobre ela e aqueles que pensam sobre a matéria precisam associá-la a uma prática. Entendemos que a valoração do diálogo teoria-prática também deve ser dada ao ensino de Ciências, da qual a Química é parte integrante.

Segundo Silva e Zanon (2000), as atividades práticas podem auxiliar na aprendizagem de conceitos científicos por meio da valorização da inter-relação teoria-prática. Porém, é essencial a ajuda pedagógica do professor que por meio de intervenções e proposições intencionais estimula os alunos a exporem suas ideias e se essas não forem adequadas os animam a modificá-las ou a produzirem outras novas. As atividades experimentais de nada adiantariam se não fossem proporcionados momentos de discussão e reflexão auxiliados pelo fornecimento de evidências experimentais, pelo uso de linguagem científica e explicação no nível teórico conceitual que só serão possíveis por meio da intervenção do professor.

As atividades práticas têm o potencial de transformar os conteúdos em conhecimentos pedagogicamente assimiláveis pelos alunos, por meio, é claro, de uma transposição didática cuidadosa. A experimentação valoriza a interação teoria-prática e realça a Ciência como uma criação humana e inacabada (SILVA e ZANON, 2000). Silva e Zanon (2000) reforçam que deve ser valorizada sempre a reflexão crítica dos resultados experimentais a partir do conhecimento teórico.

As atividades experimentais desempenham um papel crucial no ensino de Ciências, mas se forem utilizadas adequadamente. Visando os objetivos certos, tais atividades podem contribuir com o processo de ensino-aprendizagem numa perspectiva integradora, contextualizada e interdisciplinar. Para Silva, Machado e Tunes (2011), a atividade experimental “... permite, por sua estrutura e dinâmica, a formação e o desenvolvimento do pensamento analítico..." (p. 259-260).

Assim, os objetivos dessa dissertação, que pretende investigar de que maneira a utilização de modelos e modelagem numa abordagem histórica e experimental pode auxiliar na apropriação do conceito de modelos atômicos por alunos do $9^{\circ}$ ano do Ensino Fundamental, são: verificar a abordagem dos conceitos de átomo nos livros didáticos de Ciências do $9^{\circ}$ ano do Ensino Fundamental aprovados pelo Programa Nacional do Livro 
Didático/2014; elaborar, implementar e analisar uma proposição didática para investigar o processo de ensino-aprendizagem dos conceitos de átomo a partir da inserção de estratégias diferenciadas, como aulas dialógicas, experimentação e construção de modelos, diferentes daquelas propostas nos livros didáticos e investigar como a abordagem da construção histórica dos conceitos químicos pode colaborar para que os alunos desmistifiquem o caráter acabado e imutável das descobertas científicas. A seguir, passaremos à descrição metodológica da pesquisa. 


\section{METODOLOGIA}

Descreveremos a seguir a metodologia empregada no trabalho, pontuando as estratégias utilizadas para a coleta de informações, explicitando os sujeitos participantes da pesquisa e quais foram os instrumentos utilizados.

\subsection{Descrição Metodológica da Pesquisa}

O presente trabalho se encontra dividido em duas partes. Na primeira parte foi feita a verificação do tema modelos atômicos nos livros didáticos de Ciências aprovados pelo PNLD/2014. Para tal verificação foram pré-estabelecidos critérios para que houvesse um padrão de comparação entre os livros. Os critérios analisados foram: a) se os livros abordam ou não os modelos atômicos; b) se a resposta ao primeiro critério for sim, como os livros abordam os modelos atômicos; c) qual ou quais são as estratégias de ensino propostas para esse conteúdo e; d) se os livros disponibilizam ou sugerem algum material complementar. Tais critérios foram propostos durante a elaboração deste trabalho. Foram recolhidos exemplares de dezessete livros de Ciências do $9^{\circ}$ ano do Ensino Fundamental do total de vinte coleções mencionadas no Guia de Livros Didáticos de 2014. Infelizmente não foi possível adquirir todos os vinte exemplares. Para a análise das obras foi utilizada uma abordagem qualitativa e aqueles cujo não obtivemos acesso ao exemplar foram analisados apenas pelo índice disponível no Guia de Livros Didáticos.

A segunda parte consistiu na implementação de um módulo didático elaborado a partir das principais dificuldades encontradas no ensino dos modelos atômicos para alunos do $9^{\circ}$ ano do Ensino Fundamental, apresentado no apêndice deste trabalho. O módulo foi aplicado em seis momentos, cada um deles com duração aproximada de uma hora e trinta minutos, o equivalente a uma aula dupla. Todo o material necessário para o desenvolvimento das atividades previstas foi disponibilizado pela equipe de pesquisa. As intervenções ocorreram entre os dias 8 de agosto e 2 de setembro de 2014, período em que o professor regente da turma trabalharia o conteúdo do módulo. Na semana anterior ao dia 8 foi feita uma visita à 
escola, de aproximadamente dez minutos, a fim de que a equipe de pesquisa fosse apresentada à turma onde a proposta seria implementada.

A coleta de informações se deu por meio do recolhimento de atividades avaliativas que foram respondidas individualmente pelos alunos e recolhidas ao final de cada aula, pelo registro fotográfico de todos os modelos construídos pelos alunos durante a aplicação da proposição, por um diário de bordo onde foram registradas pela equipe de pesquisa as informações mais relevantes e por um gravador de áudio para que a participação dos alunos durante as discussões fossem captadas com a maior fidelidade possível. Os dados foram posteriormente analisados, quantitativamente devido ao grande número de atividades realizadas pelos alunos e qualitativamente, pois dos áudios e dos demais registros foram extraídas e analisadas falas dos alunos durante todo o processo.

\subsection{Sujeitos Participantes da Pesquisa}

O módulo foi aplicado em uma escola pública da Coordenadoria Regional de Ensino de Sobradinho, DF. A escola foi escolhida pela abertura e apoio que tem dado às pesquisas desenvolvidas pela universidade nos últimos anos. Participou da pesquisa um total de 36 alunos de uma mesma turma do $9^{\circ}$ ano do Ensino Fundamental. A turma foi selecionada pela compatibilidade de horários com a pesquisadora.

Como já foi dito, a abordagem foi feita em seis momentos, conforme prevê a proposição. A turma dispunha de duas aulas duplas por semana, o que permitiria a aplicação da proposta em três semanas. No entanto, foi necessário pausar a intervenção por uma semana após o terceiro momento devido à realização do Circuito de Ciências, evento anual do qual a escola participa, o que aumentou o tempo de aplicação da proposta para quatro semanas.

\subsection{Instrumentos da Pesquisa}

Para o desenvolvimento da pesquisa foram elaborados por nós sete textos como material de apoio para as aulas, todos relacionados ao tema modelos atômicos. Também 
foram estruturadas sete atividades experimentais, além de dois sistemas conceituais relacionados à forma de apresentação da matéria e sua natureza. Tais instrumentos foram ainda auxiliados por recursos tecnológicos e não tecnológicos. E para investigar a potencialidade do uso de tais instrumentos no processo de ensino-aprendizagem dos modelos atômicos foram elaboradas e aplicadas seis atividades avaliativas para serem respondidas após cada momento. Por meio das respostas analisadas julgaremos, por fim, a relevância do módulo no processo de ensino-aprendizagem dos modelos atômicos. Segue abaixo a estrutura do módulo didático aplicado:

Quadro1: Estrutura do módulo didático.

\begin{tabular}{|c|c|c|c|c|}
\hline Momento & Conteúdo & Objetivos & Estratégias & Avaliação \\
\hline $\begin{array}{l}\text { Primeiro } \\
\text { momento }\end{array}$ & $\begin{array}{l}\text { - Modelos } \\
\text { representativos } \\
\text { - Átomos }\end{array}$ & $\begin{array}{l}\text { - Compreender o que } \\
\text { são modelos } \\
\text { - Reconhecer o papel } \\
\text { dos modelos no meio } \\
\text { científico } \\
\text { - Conhecer o contexto } \\
\text { histórico em que o } \\
\text { átomo foi proposto pela } \\
\text { primeira vez }\end{array}$ & $\begin{array}{l}\text { - Atividade em grupo } \\
\text { "Imaginando o } \\
\text { invisível" } \\
\text { - Discussão do } \\
\text { conceito de modelos } \\
\text { - Leitura e discussão } \\
\text { do texto "Introdução } \\
\text { aos modelos atômicos" }\end{array}$ & $\begin{array}{l}\text { - Modelos } \\
\text { construídos } \\
\text { pelos alunos } \\
\text { - Participação } \\
\text { nas discussões } \\
\text { do conceito e do } \\
\text { texto } \\
\text { - Respostas da } \\
\text { "Avaliação da } \\
\text { Aprendizagem } \\
\text { 1" }\end{array}$ \\
\hline $\begin{array}{l}\text { Segundo } \\
\text { momento }\end{array}$ & $\begin{array}{l}\text { - Modelo } \\
\text { atômico de } \\
\text { Dalton }\end{array}$ & $\begin{array}{l}\text { - Conhecer as primeiras } \\
\text { evoluções do conceito } \\
\text { de átomo } \\
\text { - Compreender os } \\
\text { conceitos de átomo, } \\
\text { substâncias simples e } \\
\text { compostas } \\
\text { - Compreender a teoria e } \\
\text { o modelo atômico de } \\
\text { Dalton }\end{array}$ & $\begin{array}{l}\text { - Leitura e discussão } \\
\text { dos textos "Modelo } \\
\text { atômico de Dalton" e } \\
\text { "Modelo atômico de } \\
\text { Dalton modificado" } \\
\text { - Construção de } \\
\text { modelos } \\
\text { representativos para } \\
\text { substâncias simples e } \\
\text { compostas e para o } \\
\text { modelo atômico de } \\
\text { Dalton }\end{array}$ & $\begin{array}{l}\text { - Modelos } \\
\text { construídos } \\
\text { pelos alunos } \\
\text { - Participação } \\
\text { nas discussões } \\
\text { dos textos } \\
\text { - Respostas da } \\
\text { "Avaliação da } \\
\text { Aprendizagem } \\
\text { 2" }\end{array}$ \\
\hline $\begin{array}{c}\text { Terceiro } \\
\text { momento }\end{array}$ & $\begin{array}{l}\text { - Descoberta } \\
\text { dos elétrons }\end{array}$ & $\begin{array}{l}\text { - Reconhecer a } \\
\text { existência das cargas } \\
\text { elétricas } \\
\text { - Compreender o que } \\
\text { são elétrons }\end{array}$ & $\begin{array}{l}\text { - Leitura e discussão } \\
\text { do texto "Descoberta } \\
\text { dos elétrons" } \\
\text { - Realização das } \\
\text { atividades } \\
\text { experimentais } \\
\text { "Atritando corpos" e } \\
\text { "Esfera de raios" }\end{array}$ & $\begin{array}{l}\text { - Participação na } \\
\text { discussão do } \\
\text { texto } \\
\text { - Envolvimento } \\
\text { nas atividades } \\
\text { experimentais } \\
\text { - Respostas da } \\
\text { "Avaliação da }\end{array}$ \\
\hline
\end{tabular}




\begin{tabular}{|c|c|c|c|c|}
\hline & & & & $\begin{array}{l}\text { Aprendizagem } \\
\text { 3" }\end{array}$ \\
\hline $\begin{array}{l}\text { Quarto } \\
\text { momento }\end{array}$ & $\begin{array}{l}\text { - Modelo } \\
\text { atômico de } \\
\text { Thomson }\end{array}$ & $\begin{array}{l}\text { - Compreender a } \\
\text { estrutura do modelo } \\
\text { atômico de Thomson, } \\
\text { assim como os aspectos } \\
\text { históricos que elucidam } \\
\text { a evolução do modelo } \\
\text { atômico de Dalton para } \\
\text { este }\end{array}$ & $\begin{array}{l}\text { - Comparação } \\
\text { analógica do modelo } \\
\text { atômico de Thomson } \\
\text { com o bolo } \\
\text { formigueiro } \\
\text { - Leitura e discussão } \\
\text { do texto "Modelo } \\
\text { atômico de Thomson" } \\
\text { - Construção de } \\
\text { modelo representativo } \\
\text { para o modelo atômico } \\
\text { de Thomson }\end{array}$ & $\begin{array}{l}\text { - Participação } \\
\text { nas discussões } \\
\text { do texto e da } \\
\text { analogia } \\
\text { - Modelos } \\
\text { construídos } \\
\text { pelos alunos } \\
\text {-Respostas da } \\
\text { "Avaliação da } \\
\text { Aprendizagem } \\
\text { 4" }\end{array}$ \\
\hline $\begin{array}{l}\text { Quinto } \\
\text { momento }\end{array}$ & $\begin{array}{l}\text { - Modelo } \\
\text { atômico de } \\
\text { Rutherford }\end{array}$ & $\begin{array}{l}\text { - Compreender a } \\
\text { estrutura do modelo } \\
\text { atômico de Rutherford, } \\
\text { assim como os aspectos } \\
\text { históricos que elucidam } \\
\text { a evolução do modelo } \\
\text { atômico de Thomson } \\
\text { para este }\end{array}$ & $\begin{array}{l}\text { - Leitura e discussão } \\
\text { do texto "Modelo } \\
\text { atômico de } \\
\text { Rutherford" } \\
\text { - Apresentação de um } \\
\text { vídeo } \\
\text { - Realização das } \\
\text { atividades } \\
\text { experimentais "Pra } \\
\text { onde foi o sal?", "Em } \\
\text { busca de espaços } \\
\text { vazios" e "Enchendo } \\
\text { balão sem assoprar" } \\
\text { - Construção de } \\
\text { modelo representativo } \\
\text { para o modelo atômico } \\
\text { de Rutherford }\end{array}$ & $\begin{array}{l}\text { - Participação } \\
\text { nas discussões } \\
\text { do texto e do } \\
\text { vídeo } \\
\text { - Envolvimento } \\
\text { nas atividades } \\
\text { experimentais } \\
\text { - Modelos } \\
\text { construídos } \\
\text { pelos alunos } \\
\text { - Respostas da } \\
\text { “Avaliação da } \\
\text { Aprendizagem } \\
\text { 5” }\end{array}$ \\
\hline $\begin{array}{c}\text { Sexto } \\
\text { momento }\end{array}$ & $\begin{array}{l}\text { - Modelo } \\
\text { atômico de } \\
\text { Rutherford- } \\
\text { Bohr }\end{array}$ & $\begin{array}{l}\text { - Compreender a } \\
\text { estrutura do modelo } \\
\text { atômico de Rutherford- } \\
\text { Bohr, assim como os } \\
\text { aspectos históricos que } \\
\text { elucidam a evolução do } \\
\text { modelo atômico de } \\
\text { Rutherford para este }\end{array}$ & $\begin{array}{l}\text { - Leitura e discussão } \\
\text { do texto "Modelo } \\
\text { atômico de } \\
\text { Rutherford-Bohr" } \\
\text { - Realização da } \\
\text { atividade experimental } \\
\text { "Teste de chamas" } \\
\text { - Construção de } \\
\text { modelo representativo } \\
\text { para o modelo atômico } \\
\text { de Rutherford-Bohr }\end{array}$ & $\begin{array}{l}\text { - Participação na } \\
\text { discussão do } \\
\text { texto } \\
\text { - Envolvimento } \\
\text { na atividade } \\
\text { experimental } \\
\text { - Modelos } \\
\text { construídos } \\
\text { pelos alunos } \\
\text { - Respostas da } \\
\text { "Avaliação da } \\
\text { Aprendizagem } \\
\text { 6" }\end{array}$ \\
\hline
\end{tabular}




\section{RESULTADOS}

Nesse momento apresentaremos os resultados e discussões obtidos da verificação dos livros didáticos do $9^{\circ}$ ano do Ensino Fundamental apresentados no Guia de Livros Didáticos de 2014 e da implementação do módulo didático.

\subsection{O Ensino de Modelos Atômicos nos Livros Aprovados pelo PNLD/2014}

Como o foco desse trabalho é a abordagem dos modelos atômicos, passaremos a verificar como os conteúdos relacionados a esse tema são apresentados nas obras aprovadas pelo PNLD/2014.

Em se tratando dos conteúdos que serão aqui analisados, os conceitos de átomo estão presentes em dezoito livros de Ciências do $9^{\circ}$ ano do Ensino Fundamental de um total de vinte livros aprovados e apresentados no Guia de Livros Didáticos de 2014. Os resultados foram obtidos a partir da verificação de cada uma das dezessete obras disponibilizadas. Como não conseguimos o exemplar das outras três obras, fizemos a verificação dessas apenas pelo índice disponibilizado no Guia. Os resultados da avaliação com base nos critérios mencionados na metodologia deste trabalho estão representados no quadro abaixo.

Quadro 2: Resultado da verificação da abordagem dos modelos atômicos nos livros didáticos aprovados pelo PNLD/2014.

\begin{tabular}{|c|c|c|c|}
\hline Título do livro & Autor (es) & $\begin{array}{l}\text { Como aborda } \\
\text { os modelos } \\
\text { atômicos }\end{array}$ & $\begin{array}{c}\text { Estratégias de ensino } \\
\text { propostas }\end{array}$ \\
\hline CIÊNCIAS & $\begin{array}{l}\text { Carlos Augusto da C. Barros } \\
\text { e Wilson Roberto Paulino }\end{array}$ & $\begin{array}{l}\text { Aborda a teoria } \\
\text { atômica de } \\
\text { Dalton e faz uma } \\
\text { breve descrição } \\
\text { até o modelo } \\
\text { atômico atual }\end{array}$ & $\begin{array}{l}\text { Leitura de textos, } \\
\text { realização de atividades } \\
\text { de revisão e } \\
\text { preenchimento de um } \\
\text { mapa conceitual em } \\
\text { grupo }\end{array}$ \\
\hline $\begin{array}{l}\text { CIÊNCIAS } \\
\text { NATURAIS }\end{array}$ & $\begin{array}{l}\text { Olga Aguilar Santana, } \\
\text { Aníbal Fonseca de } \\
\text { Figueiredo Neto e Erika } \\
\text { Regina Mozena }\end{array}$ & Não aborda & Não aborda \\
\hline
\end{tabular}




\begin{tabular}{|c|c|c|c|}
\hline $\begin{array}{l}\text { CIÊNCIAS } \\
\text { NATURAIS - } \\
\text { APRENDENDO } \\
\text { COM O } \\
\text { COTIDIANO }\end{array}$ & Eduardo Leite do Canto & $\begin{array}{l}\text { Aborda a teoria } \\
\text { atômica de } \\
\text { Dalton e faz uma } \\
\text { breve descrição } \\
\text { até o modelo } \\
\text { atômico atual }\end{array}$ & $\begin{array}{l}\text { Leitura de textos e } \\
\text { realização de atividades } \\
\text { de revisão }\end{array}$ \\
\hline $\begin{array}{l}\text { CIÊNCIAS, } \\
\text { NATUREZA E } \\
\text { COTIDIANO }\end{array}$ & $\begin{array}{l}\text { José Trivellato Júnior, Silvia } \\
\text { Luzia F. Trivellato, Marcelo } \\
\text { Tadeu Motokane, Júlio } \\
\text { Cézar Foschini Lisboa e } \\
\text { Carlos Aparecido Kantor }\end{array}$ & $\begin{array}{l}\text { Aborda os } \\
\text { modelos } \\
\text { atômicos de } \\
\text { Dalton, Thomson } \\
\text { e Rutherford }\end{array}$ & $\begin{array}{l}\text { Proposta de uma } \\
\text { atividade experimental } \\
\text { em grupo sobre } \\
\text { modelos, leitura de } \\
\text { textos, realização de } \\
\text { atividades de revisão e } \\
\text { propostas de discussão e } \\
\text { reflexão }\end{array}$ \\
\hline $\begin{array}{l}\text { CIÊNCIAS NO } \\
\text { SÉCULO XXI }\end{array}$ & Íris Stern & $\begin{array}{l}\text { Aborda } \\
\text { (verificação feita } \\
\text { pelo índice) }\end{array}$ & Exemplar não disponível \\
\hline $\begin{array}{l}\text { CIÊNCIAS NOS } \\
\text { DIAS DE HOJE }\end{array}$ & Renata Moretti & $\begin{array}{l}\text { Aborda a teoria } \\
\text { atômica de } \\
\text { Dalton e faz uma } \\
\text { breve descrição } \\
\text { até o modelo } \\
\text { atômico atual }\end{array}$ & $\begin{array}{l}\text { Leitura de textos e } \\
\text { realização de atividades } \\
\text { de revisão }\end{array}$ \\
\hline $\begin{array}{l}\text { CIÊNCIAS NOVO } \\
\text { PENSAR - EDIÇÃO } \\
\text { RENOVADA }\end{array}$ & $\begin{array}{l}\text { Demétrio Ossowski Gowdak } \\
\text { e Eduardo Lavieri Martins }\end{array}$ & $\begin{array}{l}\text { Aborda a } \\
\text { estrutura atômica } \\
\text { do modelo atual }\end{array}$ & $\begin{array}{l}\text { Leitura de textos e } \\
\text { realização de atividades } \\
\text { de revisão }\end{array}$ \\
\hline $\begin{array}{l}\text { CIÊNCIAS PARA } \\
\text { NOSSO TEMPO }\end{array}$ & $\begin{array}{l}\text { Washington Luiz P. de } \\
\text { Carvalho, João Amadeus } \\
\text { Pereira Alves e Laercio } \\
\text { Caetano }\end{array}$ & $\begin{array}{l}\text { Aborda os } \\
\text { modelos } \\
\text { atômicos de } \\
\text { Dalton, } \\
\text { Thomson, } \\
\text { Rutherford e } \\
\text { Bohr }\end{array}$ & $\begin{array}{l}\text { Leitura de textos, } \\
\text { realização de atividades } \\
\text { de revisão e sugestões de } \\
\text { livro e filme }\end{array}$ \\
\hline $\begin{array}{l}\text { COMPANHIA DAS } \\
\text { CIÊNCIAS }\end{array}$ & $\begin{array}{l}\text { Eduardo Schechtmann, } \\
\text { Herick Martin Velloso, João } \\
\text { Usberco, José Manoel } \\
\text { Martins e Luiz Carlos Ferrer }\end{array}$ & $\begin{array}{l}\text { Aborda os } \\
\text { modelos } \\
\text { atômicos de } \\
\text { Dalton, } \\
\text { Thomson, } \\
\text { Rutherford e } \\
\text { Rutherford-Bohr }\end{array}$ & $\begin{array}{l}\text { Leitura de textos, } \\
\text { realização de atividades } \\
\text { de revisão e propostas de } \\
\text { duas atividades } \\
\text { experimentais em grupo, } \\
\text { uma relacionada a } \\
\text { modelos e a outraao } \\
\text { modelo atômico de } \\
\text { Rutherford-Bohr }\end{array}$ \\
\hline $\begin{array}{l}\text { JORNADAS.CIE - } \\
\text { CIÊNCIAS }\end{array}$ & $\begin{array}{l}\text { Maíra Rosa Carnevalle } \\
\text { (Editora responsável) }\end{array}$ & $\begin{array}{l}\text { Aborda a } \\
\text { estrutura atômica } \\
\text { do modelo atual }\end{array}$ & $\begin{array}{l}\text { Leitura de textos, } \\
\text { realização de atividades } \\
\text { de revisão e proposta de } \\
\text { atividade experimental } \\
\text { em grupo sobre modelos }\end{array}$ \\
\hline $\begin{array}{l}\text { CIÊNCIAS DA } \\
\text { NATUREZA }\end{array}$ & Helvio Nicolau Moises & $\begin{array}{l}\text { Aborda a teoria } \\
\text { atômica de } \\
\text { Dalton e faz uma } \\
\text { breve descrição } \\
\text { até o modelo } \\
\text { atômico de } \\
\text { Rutherford }\end{array}$ & $\begin{array}{l}\text { Leitura de textos e } \\
\text { realização de atividades } \\
\text { de revisão }\end{array}$ \\
\hline
\end{tabular}




\begin{tabular}{|c|c|c|c|}
\hline $\begin{array}{l}\text { OBSERVATÓRIO } \\
\text { DE CIÊNCIAS }\end{array}$ & $\begin{array}{l}\text { Rita Helena Bröckelmann } \\
\text { (Editora responsável) }\end{array}$ & $\begin{array}{l}\text { Aborda os } \\
\text { modelos } \\
\text { atômicos de } \\
\text { Dalton, } \\
\text { Thomson, } \\
\text { Rutherford e } \\
\text { Bohr }\end{array}$ & $\begin{array}{l}\text { Leitura de textos, } \\
\text { realização de atividades } \\
\text { de revisão e sugestão de } \\
\text { site }\end{array}$ \\
\hline $\begin{array}{l}\text { OFICINA DO } \\
\text { SABER CIÊNCIAS }\end{array}$ & $\begin{array}{l}\text { Alice Mendes Carvalho L. } \\
\text { Costa e Carla Newton } \\
\text { Scrivano }\end{array}$ & $\begin{array}{l}\text { Aborda } \\
\text { (verificação feita } \\
\text { pelo índice) }\end{array}$ & Exemplar não disponível \\
\hline $\begin{array}{l}\text { PARA VIVER } \\
\text { JUNTOS - } \\
\text { CIÊNCIAS }\end{array}$ & $\begin{array}{l}\text { Ana Luiza Petillo Nery e } \\
\text { Gustavo Isaac Killner }\end{array}$ & $\begin{array}{l}\text { Aborda os } \\
\text { modelos } \\
\text { atômicos de } \\
\text { Dalton, } \\
\text { Thomson, } \\
\text { Rutherford e } \\
\text { Bohr }\end{array}$ & $\begin{array}{l}\text { Leitura de textos, } \\
\text { realização de atividades } \\
\text { de revisão e proposta de } \\
\text { uma atividade } \\
\text { experimental em grupo } \\
\text { sobre modelos }\end{array}$ \\
\hline $\begin{array}{l}\text { PERSPECTIVA - } \\
\text { CIÊNCIAS }\end{array}$ & $\begin{array}{l}\text { Ana Paula Bemfeito e Carlos } \\
\text { Eduardo Pinto }\end{array}$ & $\begin{array}{l}\text { Aborda os } \\
\text { modelos } \\
\text { atômicos de } \\
\text { Dalton, } \\
\text { Thomson, } \\
\text { Rutherford e } \\
\text { Bohr }\end{array}$ & $\begin{array}{l}\text { Leitura de textos, } \\
\text { realização de atividades } \\
\text { de revisão, proposta de } \\
\text { uma atividade } \\
\text { experimental em grupo } \\
\text { sobre modelos, } \\
\text { sugestões de sites }\end{array}$ \\
\hline $\begin{array}{l}\text { PROJETO } \\
\text { ARARIBÁ - } \\
\text { CIÊNCIAS }\end{array}$ & $\begin{array}{l}\text { Vanessa Shimabukuro } \\
\text { (Editora responsável) }\end{array}$ & $\begin{array}{l}\text { Aborda a } \\
\text { estrutura atômica } \\
\text { do modelo atual }\end{array}$ & $\begin{array}{l}\text { Leitura de textos e } \\
\text { realização de atividades } \\
\text { de revisão }\end{array}$ \\
\hline $\begin{array}{l}\text { PROJETO RADIX - } \\
\text { CIÊNCIAS }\end{array}$ & $\begin{array}{l}\text { Leonel Delvai Favalli, } \\
\text { Karina Alessandra P. da } \\
\text { Silva e Elisangela Andrade }\end{array}$ & $\begin{array}{l}\text { Aborda os } \\
\text { modelos } \\
\text { atômicos de } \\
\text { Dalton, } \\
\text { Thomson, } \\
\text { Rutherford e } \\
\text { Bohr }\end{array}$ & $\begin{array}{l}\text { Leitura de textos e } \\
\text { realização de atividades } \\
\text { de revisão }\end{array}$ \\
\hline $\begin{array}{l}\text { PROJETO TELÁRIS } \\
\text { - CIÊNCIAS }\end{array}$ & Fernando Gewandsznajder & $\begin{array}{l}\text { Aborda a teoria } \\
\text { atômica de } \\
\text { Dalton e faz uma } \\
\text { breve descrição } \\
\text { até o modelo } \\
\text { atômico de } \\
\text { Rutherford-Bohr }\end{array}$ & $\begin{array}{l}\text { Leitura de textos, } \\
\text { realização de atividades } \\
\text { de revisão e proposta de } \\
\text { uma atividade } \\
\text { experimental em grupo } \\
\text { sobre o modelo atômico } \\
\text { atual }\end{array}$ \\
\hline $\begin{array}{l}\text { PROJETO VELEAR } \\
\text { - CIÊNCIAS }\end{array}$ & $\begin{array}{l}\text { Carmen Maria de Caro, } \\
\text { Helder de Figueiredo e } \\
\text { Paula, Mairy Barbosa L. dos } \\
\text { Santos, Maria Emília C. de } \\
\text { Castro Lima, Nilma Soares } \\
\text { da Silva, Orlando G. de } \\
\text { Aguiar Júnior, Ruth Schmitz } \\
\text { de Castro e Selma } \\
\text { Ambrosina de M. Braga }\end{array}$ & $\begin{array}{l}\text { Não aborda } \\
\text { (verificação feira } \\
\text { pelo índice) }\end{array}$ & Exemplar não disponível \\
\hline $\begin{array}{l}\text { VONTADE DE } \\
\text { SABER CIÊNCIAS }\end{array}$ & $\begin{array}{l}\text { Leandro Pereira de Godoy e } \\
\text { Marcela Yaemi Ogo }\end{array}$ & $\begin{array}{l}\text { Aborda os } \\
\text { modelos } \\
\text { atômicos de } \\
\text { Dalton, }\end{array}$ & $\begin{array}{l}\text { Leitura de textos e } \\
\text { realização de atividades } \\
\text { de revisão }\end{array}$ \\
\hline
\end{tabular}




\begin{tabular}{|l|l|l|l|}
\hline & $\begin{array}{l}\text { Thomson, } \\
\text { Rutherford e } \\
\text { Bohr }\end{array}$ \\
\hline
\end{tabular}

Conforme mostra o quadro, dezoito livros abordam os modelos atômicos. Dentre aqueles cujo exemplar foi verificado, dezesseis utilizam de textos para apresentar os conteúdos e sugerem um conjunto de atividades de revisão, seis propõem algum tipo de atividade experimental, três trazem sugestões de materiais complementares (que podem ser filmes, revistas, livros ou sites), um sugere o preenchimento de um mapa conceitual e apenas um traz propostas de discussão e reflexão.

Desta análise podemos afirmar que não há muita variação entre as estratégias presentes nos livros didáticos, a maioria se enquadra em estratégias consideradas tradicionais que, conforme afirma Correia (2011), se utilizadas de forma exclusiva são inadequadas e insuficientes para proporcionar um ensino de qualidade. A minoria dos livros propõe algum tido de atividade diferenciada, mas vale ressaltar que a execução de tais atividades depende da abordagem feita pelo professor.

Conforme já citamos, o livro didático deve ser utilizado em sala de aula como instrumento de apoio e deve estar associado a outros recursos a fim de proporcionar um ensino dinâmico e inovador (ECHEVERRÍA, MELLO e GAUCHE, 2011). Sendo assim, apesar da inadequação na abordagem dos conteúdos relacionados aos modelos atômicos nos livros didáticos, cabe ao professor realizar uma abordagem diferenciada que permita a aprendizagem consistente dos conceitos.

\subsection{O Ensino de Modelos Atômicos por Meio do Módulo Didático}

Na semana anterior ao início das aplicações foi feita uma visita à escola a fim de que houvesse um primeiro contato entre pesquisadora e alunos. Além das apresentações pessoais, foi falado um pouco a respeito do trabalho que seria desenvolvido com a turma. Na semana seguinte demos início à aplicação da proposta. A seguir, os primeiros relatos dessa aplicação. 


\subsubsection{Primeiro Momento}

Aula ministrada no dia 08 de agosto de 2014 das $8 \mathrm{~h} 35 \mathrm{~min}$ às $10 \mathrm{~h} 05 \mathrm{~min}$. Estiveram presentes nessa aula 32 alunos de um total de 36.

A primeira parte da aula consistiu na realização de uma atividade que chamamos de "Imaginando o invisível" em que, por meio do manuseio de caixas lacradas, os alunos, em grupos, tentam deduzir informações a respeito de um objeto inserido no interior da caixa. Em seguida, com base nas percepções obtidas, os alunos representam na forma de desenho como imaginam o objeto em questão. Essa atividade tem como objetivo possibilitar uma melhor compreensão do que são os modelos atômicos, já que, apesar do átomo nunca ter sido visto, por meio de suas propriedades foram propostos diferentes modelos que pudessem representálo.

Para a aplicação da atividade "Imaginando o invisível" a turma foi dividida em 4 grupos. Cada grupo recebeu uma caixa lacrada contendo um objeto diferente. Inicialmente os alunos manusearam as caixas, cada grupo a sua, e fizeram sugestões do que poderia ter dentro da mesma. A maioria sugeriu objetos comuns ao cotidiano deles. Nesse momento chamamos atenção para que os alunos, por meio das propriedades percebidas ao manusear a caixa, tentassem deduzir a forma, tamanho e material do objeto, já que este poderia não ser comum a eles.

As caixas foram numeradas de 1 a 4 . Na caixa 1 havia uma meia esfera de silicone, na caixa 2 havia uma pilha, na caixa 3 havia um copinho de iogurte no formato de um morango preenchido com grãos de arroz e na caixa 4 havia uma borracha, conforme mostram as figuras 2 e 3.
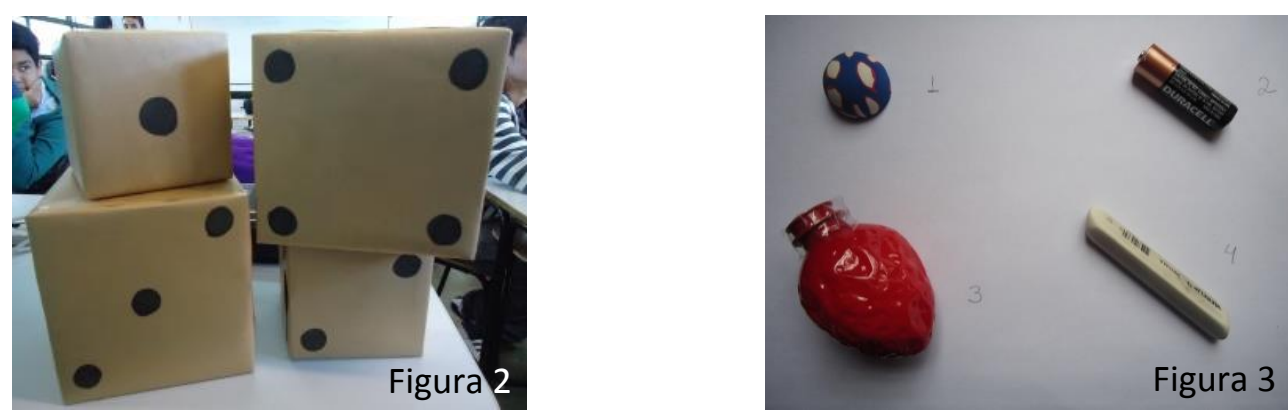

Figura 2: Caixas utilizadas na realização da atividade "Imaginando o invisível".

Figura 3: Objetos que foram colocados dentro das caixas ilustradas na figura 2. 
O grupo que estava com a caixa 1, a qual havia uma meia esfera de silicone, sugeriu que tinha uma borracha dentro da caixa. Por mais que o grupo não tenha acertado qual era o objeto conseguiram fazer deduções em relação ao material de que ele era feito. Foi possível perceber isso por meio da fala de um aluno: "Ela tem uma certa aderência e tem que virar mais a caixa pra ela cair, pra ela trocar de posição.". Ao final da atividade o grupo concluiu ser algo semelhante à roda de um carrinho de brinquedo feita de borracha.

O grupo que estava com a caixa 2, que tinha uma pilha, sugeriu que havia um carrinho dentro da caixa. Quando perguntamos o porquê dessa sugestão um aluno respondeu: "Quando é assim vai descendo retinho, aí quando eu viro assim fica tipo capotando.", indicando as posições com a caixa.

Sabendo-se da inexistência do carrinho dentro da caixa pedimos ao grupo que movimentasse o "carrinho" na posição normal, com as rodas para baixo e depois na posição contrária, em que o "carrinho" estaria com as rodas para cima. Das duas maneiras o objeto deslizou igualmente na caixa. A partir dessas novas informações uma aluna afirmou: "Então não é um carrinho.". O grupo entrou em discordância e não chegou a uma conclusão definitiva, mas sugestões diversas surgiram tendo por base os movimentos percebidos ao movimentar a caixa.

O grupo que estava com a caixa 3, que armazenava um recipiente de iogurte no formato de um morango e cheio de grãos arroz, também sugeriu que havia um carrinho dentro da caixa, com exceção de apenas uma aluna que percebeu uma irregularidade no movimento do objeto. Assim como fizemos com o grupo da caixa 1, pedimos para este grupo movimentar a caixa com o objeto em diferentes posições, sugerindo que tentassem movimentar o suposto “carrinho" em pé e com as rodas viradas para cima. Após esse procedimento e ao perceberem um barulho sutil causado pelo movimento dos grãos de arroz dentro do recipiente uma aluna chegou a sugerir que fosse uma bolinha. Ela disse: "Se não for um carrinho é aquela bolinha parecendo um pinguinho de água, assim, que brilha.", gesticulando com as mãos.

O grupo que estava com a caixa 4, que tinha uma borracha na forma de um prisma, sugeriu que havia mesmo uma borracha dentro da caixa baseado na aderência e na forma como o objeto se movia. Essa informação pode ser constatada por meio da fala de uma aluna que disse: "Tem hora que ela gruda.". Quando questionados em relação à como seria essa borracha, descreviam uma borracha tradicional de formato retangular.

Dando continuidade a essa primeira etapa da aula, pedimos aos alunos que desenhassem em uma folha branca como eles imaginavam ser o objeto. 
Os grupos que estavam com as caixas 2 e 3 insistiam na ideia de que dentro da caixa havia um carrinho. Uma aluna, cheia de convicções, tentou convencer os demais dizendo: "Gente, eu já coloquei um carrinho dentro de uma caixa.". Outros alunos justificaram a indiferença dos movimentos do "carrinho" em diferentes posições supondo que o objeto seria um carrinho com oito rodas capaz de se mover do mesmo modo na posição normal ou com o teto virado para baixo. Nesse momento, trocamos as caixas desses dois grupos para que mais alunos pudessem opinar em relação ao objeto. Para a maioria dos alunos tinha um carrinho nas duas caixas. Um deles disse: “É o mesmo que o outro, só que o outro é maior e esse daqui é menor. ", indicando a caixa que estava em sua mão.

Então dissemos aos alunos que em hipótese alguma havia dois objetos iguais nas caixas. Como deduziram que em sua própria caixa tinha um carrinho, na outra não poderia ter.

Ambos os grupos, sem dar muitas explicações, sugeriram que no outro grupo o objeto seria uma esfera e insistiram na ideia de que em sua própria caixa havia mesmo um carrinho. O resultado da dinâmica pode ser observado nos desenhos produzidos pelos grupos, como mostram as imagens a seguir.
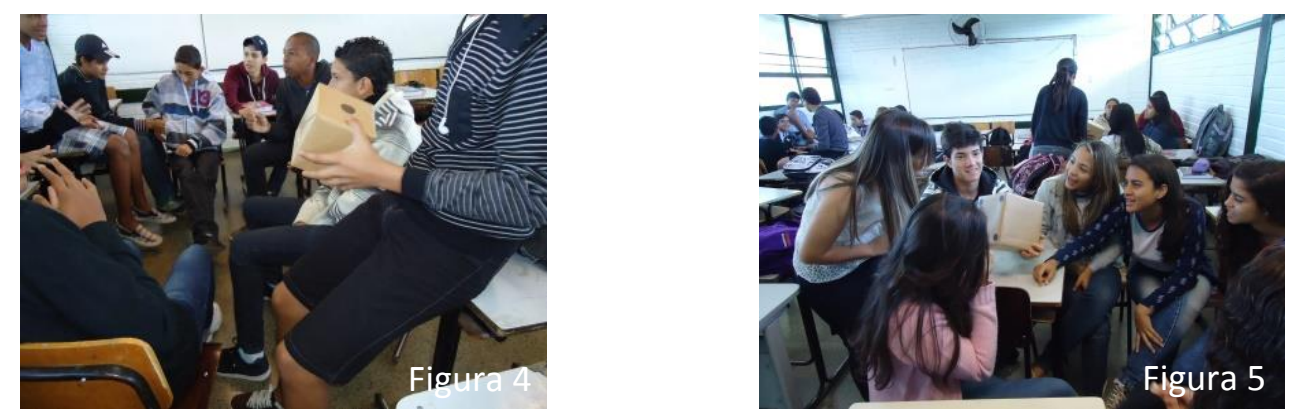

Figuras 4 e 5: Desenvolvimento da atividade "Imaginando o invisível".
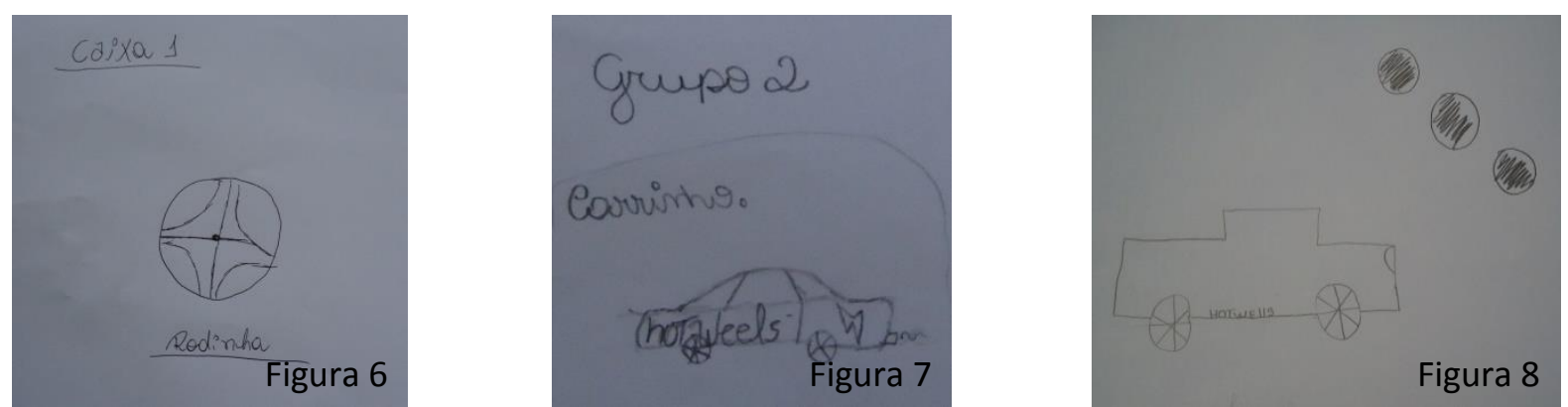

Figura 6: Desenho produzido pelo grupo 1.

Figura 7: Desenho produzido pelo grupo 2.

Figura 8: Desenho produzido pelo grupo 3. 


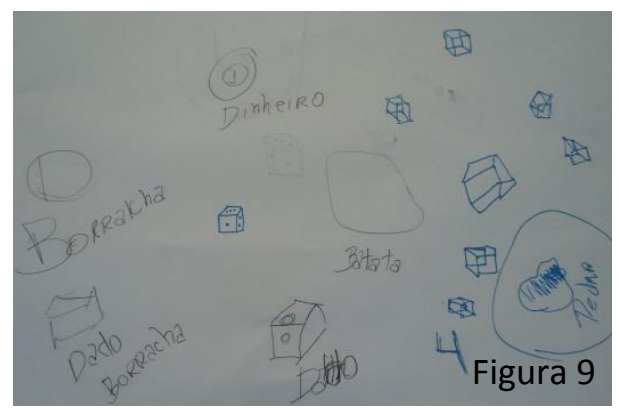

Figura 9: Desenho produzido pelo grupo 4.

Percebe-se que apesar de ter sugerido uma borracha, o grupo 4 desenhou vários objetos que poderiam estar na caixa, mas sem apresentar argumentos para a sugestão desses.

Após recolhidos os desenhos, iniciamos a discussão coletiva do conceito de modelo. Primeiramente perguntamos aos alunos o que seria o desenho em relação ao objeto. Alguns alunos responderam que o desenho seria uma cópia do objeto, mas logo outros discordaram dizendo que não poderia ser uma cópia porque não se pode copiar o que não se vê. Outras sugestões foram surgindo até que em um dado momento foi dito a eles que os desenhos produzidos podiam também ser chamados de modelos. Então perguntamos a eles o que seria um modelo. Dentre as várias respostas surgiram "É algo que você imagina que seja." e "É tipo uma prévia que você faz antes de criar alguma coisa.".

Demos continuidade à abordagem do conceito de modelo por meio de slides (apêndices A, B e C) que traziam a definição científica e importantes informações a respeito dos modelos, utilizando uma metodologia expositiva dialógica. Durante a explicação foram citados como exemplos os modelos do Sistema Solar e de uma célula. Encerramos essa abordagem dizendo aos alunos que as caixas utilizadas na atividade "Imaginando o invisível" não seriam abertas porque, assim como havia sido discutido anteriormente, muitos modelos foram construídos sem que fosse possível visualizar o fenômeno modelado.

Introduzimos ainda nessa aula o conceito de átomo. Começamos a abordagem perguntando aos alunos do que as coisas são feitas, as cadeiras, as mesas, o quadro, a parede, as árvores... Eles iam respondendo até chegar a uma determinada matéria prima e paravam, de forma repetitiva, nas diversas abordagens feitas. Em seguida distribuímos o texto 1 (apêndice D) intitulado "Introdução aos modelos atômicos", por nós elaborado, e respondemos a pergunta "Do que as coisas são feitas?" durante a leitura e discussão desse. Notamos que nesse momento da aula os alunos interagiram mais, provavelmente por se sentirem mais a vontade com o decorrer da aula. 
Finalizando a aula entregamos a Avaliação da Aprendizagem 1 - AA1 (apêndice E), que contempla algumas questões relativas à temática abordada durante a aula. Essa avaliação foi respondida individualmente e entregue a pesquisadora ao final da aula. Quanto aos resultados da primeira avaliação, temos:

A questão 1 perguntava “O que são modelos científicos?”. As respostas dissertativas foram divididas em sete categorias para facilitar as análises, conforme mostra a tabela 1:

Tabela 1: Respostas da questão 1 da Avaliação da Aprendizagem 1.

\begin{tabular}{|l|l|c|}
\hline O que são modelos científicos? & 07 \\
\hline A & São representações parciais & 16 \\
\hline B & São representações parciais do que não se vê & 05 \\
\hline C & Não são idênticos aos modelados / São semelhantes aos modelados & 02 \\
\hline D & Podem ser modificados & 02 \\
\hline E & São ferramentas auxiliadoras para o estudo & 02 \\
\hline F & São criações humanas & 06 \\
\hline G & Outras & 0 \\
\hline
\end{tabular}

Como podemos ver, das 32 avaliações analisadas, 07 respostas indicam que modelos são representações parciais, em 16 os alunos sugerem que são representações parciais do que não se vê, 05 fazem referência ao fato do modelo não ser idêntico ao fenômeno modelado, 02 dizem que os modelos podem ser modificados, 02 indicam que são ferramentas auxiliadoras para o estudo, 02 que são criações humanas e 06 respostas não se enquadram em nenhuma das categorias acima. O número de respostas é superior ao número de questionários porque uma mesma resposta pode atender a mais de uma categoria.

Percebe-se que o número de respostas em que os alunos descrevem os modelos como representações parciais do que não se vê é bastante significativo, corresponde à metade do número de questionários. Entendemos que tais respostas tenham sido influenciadas pela atividade realizada "Imaginando o invisível" em que os alunos fizeram justamente um modelo de algo que não se viu. Justificamos assim a necessidade de uma abordagem direcionada a esse ponto no próximo momento com o intuito de sanar tal distorção conceitual. As demais respostas, com exceção da letra G (Outras), correspondem ao conceito de modelo que foi abordado durante a aula. 
A questão 2 perguntava “Os modelos científicos atualmente aceitos pela comunidade científica são definitivos? Se a sua resposta para essa pergunta tiver sido não, diga o que pode levar a comunidade científica a substituir ou modificar um modelo.”. As respostas foram classificadas em categorias para facilitar as análises, conforme mostram as tabelas a seguir:

Tabela 2: Respostas da questão 2 (parte a) da Avaliação da Aprendizagem 1.

\begin{tabular}{|l|l|c|}
\hline \multicolumn{3}{|c|}{$\begin{array}{l}\text { Os modelos científicos atualmente aceitos } \\
\text { pela comunidade científica são definitivos? }\end{array}$} \\
\hline A & Sim & 0 \\
\hline B & Não & 32 \\
\hline
\end{tabular}

Tabela 3: Respostas da questão 2 (parte b) da Avaliação da Aprendizagem 1.

\begin{tabular}{|l|l|l|}
\hline \multicolumn{2}{|l|}{$\begin{array}{l}\text { Se a sua resposta para essa pergunta tiver sido não, diga o que pode levar a } \\
\text { comunidade científica a substituir ou modificar um modelo. }\end{array}$} \\
\hline C & Surgimento de novas informações & 14 \\
\hline D & Diferentes posicionamentos científicos & 02 \\
\hline E & Aprimoramento dos estudos & 04 \\
\hline F & Outras & 12 \\
\hline
\end{tabular}

Os dados da tabela 2 mostram que todos os 32 alunos que responderam a avaliação entendem que os modelos científicos não são definitivos. Esse fato nos indica que a abordagem acima descrita superou a abordagem criticada por Marques e Caluzi (2003) em que os conteúdos científicos são apresentados de forma acabada e imutável.

Já na tabela 3 podemos ver que, 14 alunos atribuem como causa da modificação ou substituição de um modelo científico o surgimento de novas informações, 02 atribuem a principal causa aos diferentes posicionamentos científicos, 04 atribuem ao aprimoramento dos estudos e 12 respostas não classificam em nenhumas das alternativas anteriores. Para essa questão foi atribuída apenas uma categoria por resposta.

Vemos que, com exceção da letra F (Outras), as respostas representam as razões para tais alterações discutidas em aula.

A questão 3 perguntava "Para os filósofos gregos Demócrito e Leucipo o que seria o átomo?". As respostas dissertativas foram divididas em seis categorias, conforme mostra a tabela a seguir: 
Tabela 4: Respostas da questão 3 da Avaliação da Aprendizagem 1.

\begin{tabular}{|l|l|l|}
\hline \multicolumn{2}{|l|}{ Para os filósofos gregos Demócrito e Leucipo o que seria o átomo? } \\
\hline A & Uma partícula indivisível & 26 \\
\hline B & Possuem formas variadas & 06 \\
\hline C & Possuem tamanhos variados & 06 \\
\hline D & São muito pequenos & 05 \\
\hline E & Não podem ser vistos & 03 \\
\hline F & É a combinação dos 4 elementos: ar, terra, fogo e água & 01 \\
\hline
\end{tabular}

Como podemos ver, 26 alunos se referem ao átomo como partícula indivisível, 06 fazem referência as suas variadas formas, 06 fazem referência aos seus variados tamanhos, 05 dizem que são estruturas muito pequenas, 03 que eles não podem ser vistos e 01 que é uma combinação dos 4 elementos da natureza: ar, terra, fogo e água. O número de respostas é superior ao número de questionários porque uma mesma resposta pode atender a mais de uma categoria dentre as listadas na tabela.

Analisando tais informações podemos perceber, com exceção de apenas uma resposta, que todas as demais abordam características correspondentes ao átomo de Demócrito e Leucipo. Quanto à resposta que não corresponde ao conceito (letra F), percebe-se uma clara confusão com a crença de alguns filósofos que acreditavam que toda a matéria era constituída pelos quatro elementos da natureza, citados no mesmo texto em que foi abordado o átomo de Demócrito e Leucipo. Concluídas as análises desse primeiro momento, seguimos para os relatos do segundo momento.

\subsubsection{Segundo Momento}

Aula ministrada no dia 12 de agosto de 2014 das 7 h00min às 8 h35min. Estiveram presentes nessa aula 29 alunos de um total de 36.

Não foi possível concluir tudo o que estava previsto para esse dia. Calculamos que teríamos aproximadamente 1 hora e 35 minutos de aula, porém o que prevíamos ser o horário de início da aula é na realidade o horário em que o portão é aberto, além do mais, o professor regente requisitou alguns minutos da aula para devolutiva de atividades desenvolvidas antes do início da nossa intervenção, o que nos impediu de concluir o cronograma do dia. 
Iniciamos a aula retomando os conceitos de modelo e átomo discutidos na aula anterior. Foi possível perceber na AA1 que os alunos associaram os modelos a fenômenos não visíveis, provavelmente por causa da atividade "Imaginado o invisível" em que eles modelaram um objeto não visualizado, então abordamos esse conceito dando ênfase à reestruturação dessa definição.

Dando prosseguimento, fizermos uma breve introdução ressaltando o fato de que o átomo nunca foi visto. Distribuímos e fizemos a leitura coletiva do texto 2 (apêndice F) por nós elaborado e intitulado "Modelo atômico de Dalton". Durante as leituras dos textos sempre um aluno se prontificava a ler o primeiro parágrafo e os demais continuavam voluntariamente.

Após a leitura, fizemos a discussão coletiva do texto analisando um a um dos aspectos da teoria atômica de Dalton. Quando necessário voltávamos ao texto a relíamos alguns trechos. Foi possível deduzir pelo comportamento dos alunos que estava havendo dificuldades na compreensão do conteúdo, isso fez com que os alunos interagissem menos. A estratégia utilizada foi insistir em saber quais eram as principais dúvidas para tentar saná-las. A partir do momento em que os primeiros alunos se arriscaram a perguntar e a expor suas dúvidas, ainda um pouco intimidados, os demais começaram a interagir concordando ou complementado a pergunta dos que tomaram a iniciativa. As perguntas foram muitas, mas creio que esse cenário contribuiu muito para o desenvolvimento e compreensão do conteúdo.

Depois da discussão do texto pedimos aos alunos que construíssem modelos para representar o modelo atômico de Dalton e para representar substâncias simples e compostas de acordo com as ideias de Dalton. Foram sugeridas as substâncias hidrogênio, oxigênio e água. Todos os materiais necessários para essa atividade (massinha de modelar, bolinhas de isopor e palitos de madeira) foram disponibilizados por nós. Durante o período da construção dos modelos muitos alunos se distraíram construindo bonequinhos e animais com a massinha que foi disponibilizada para a realização da atividade. Por essa razão foi necessário chamar atenção dos alunos algumas vezes para que voltassem a se concentrar na atividade pedida. $\mathrm{O}$ tempo gasto nessa etapa foi maior que o previsto. Esse fato nos levou a reconsiderar o uso da massinha em outros momentos. A agitação e a diminuição do tempo de aula não nos permitiu concluir todas as atividades previstas para esse dia. Após esse momento os alunos deveriam ler e discutir o texto que abordava as modificações no modelo de Dalton, em seguida deveriam construir modelos para sustâncias simples e compostas de acordo com essas modificações e, para finalizar os alunos deveriam responder a Avaliação da Aprendizagem 2. Essas etapas apenas foram concluídas na aula seguinte. 
Concluímos a intervenção com a construção dos modelos de acordo com Dalton (atividade com a massinha de modelar e demais materiais). Em seguida, o professor assumiu a turma para a devolutiva de uma atividade realizada anteriormente. Nessa etapa, o professor comentou que as terças-feiras o número de alunos em sala geralmente é menor, pois a aula ocorre no primeiro horário e os alunos atrasados são impedidos de entrar em sala.

Algumas representações do modelo atômico de Dalton e de substâncias simples e compostas de acordo com esse modelo elaboradas pelos estudantes podem ser observadas nas figuras a seguir.
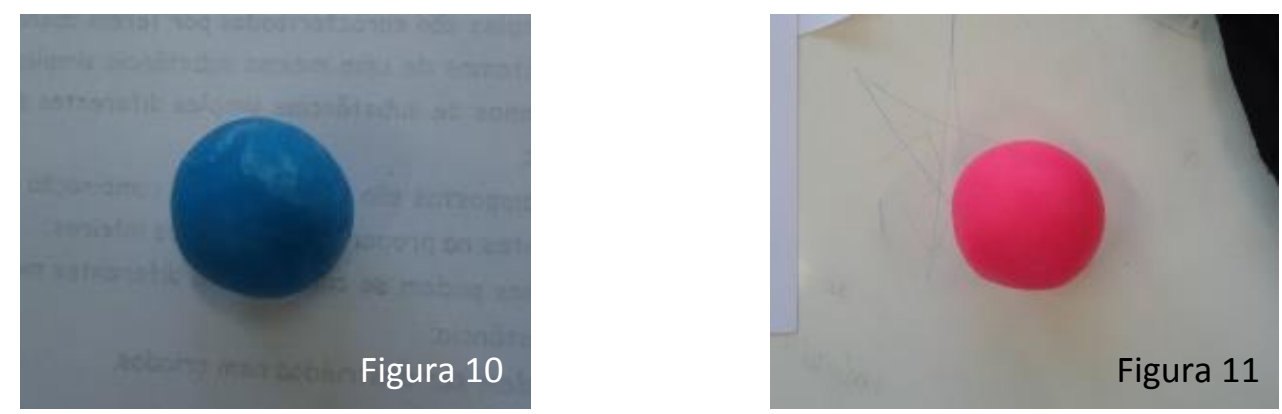

Figuras 10 e 11: Representação do átomo de Dalton construída por um aluno.
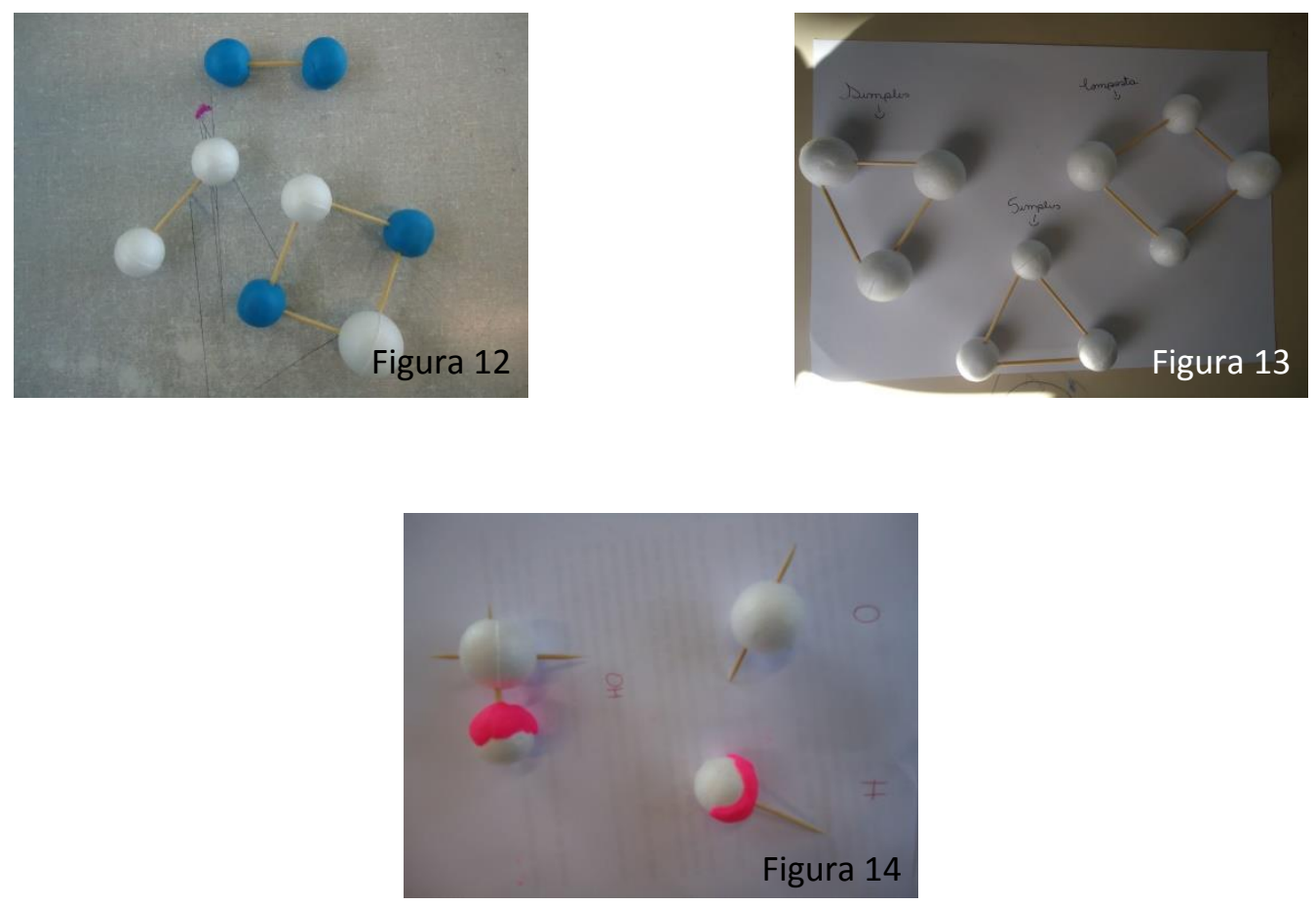

Figuras 12, 13 e 14: Representação de substâncias simples e compostas segundo o modelo de Dalton construída por um aluno.

A representação do átomo segundo o modelo atômico de Dalton foi expressa pela grande maioria dos alunos como uma esfera maciça, como observado nas figuras 10 e 11 . 
Essa representação do átomo condiz com a representação apresentada pelos livros didáticos. Alguns alunos fizeram na representação do átomo alguns detalhes com cores de massinha diferentes. Acreditamos que tais estruturas não tenham sido justificadas por um erro conceitual, e sim por distrações e brincadeiras com a massinha. Quando perguntávamos o que seriam tais estruturas os alunos respondiam que não era nada específico.

Quanto à representação das substâncias simples e compostas segundo o modelo de Dalton, a quase totalidade dos alunos representaram as substâncias simples cada uma com um tipo de bolinha e as compostas com os dois tipos de bolinhas juntas, conforme podemos observar nas figuras acima. Na figura 12 o aluno representou uma das substâncias simples com bolinhas azuis, a outra com bolinhas brancas e a composta com bolinhas azuis e brancas. Na figura 13 o aluno representou uma das substâncias simples com bolinhas menores, a outra com bolinhas maiores e a substância composta com bolinhas maiores e menores juntas.

No comando da atividade foi sugerido que os alunos representassem as substâncias hidrogênio, oxigênio e água, e apesar de terem utilizado várias bolinhas para fazer tal representação é possível perceber que as substâncias simples foram representadas com bolinhas iguais, as substâncias simples diferentes foram representadas por bolinhas diferentes e as substâncias compostas foram representadas por bolinhas diferentes em uma mesma estrutura. A única exceção são os modelos ilustrados na figura 14 em que o aluno representou o hidrogênio com uma única bolinha em cor branca e rosa, o oxigênio com uma única bolinha de cor branca e a água com uma bolinha branca e uma bolinha branca e rosa juntas. Com base nesses resultados achamos relevante verificar e ressaltar com os alunos na próxima aula que cada bolinha representa um único átomo e orientá-los de maneira diferente quanto à execução dos próximos modelos de substâncias. Finalizando as análises dessa aula, partiremos aos relatos do terceiro momento.

\subsubsection{Terceiro Momento}

Aula ministrada no dia 15 de agosto de 2014 das 8 h35min às $10 \mathrm{~h} 05 \mathrm{~min}$. Estiveram presentes nessa aula 26 alunos de um total de 36 . 
Essa aula estava com o tempo contado, pois devido aos imprevistos da aula anterior precisávamos concluir as atividades previstas para o segundo momento (modelo de Dalton modificado e a Avaliação da Aprendizagem 2) e todo o terceiro momento.

Introduzimos a aula retomando alguns conceitos já abordados, relembramos os principais aspectos do modelo atômico de Dalton e as definições de substâncias simples e compostas de acordo com esse modelo. Aproveitamos também para fazer uma comparação entre o modelo atômico de Dalton e o modelo do átomo de Dalton construído pelos alunos no intuito de que eles pudessem perceber que os modelos possuem aspectos similares relevantes, mas que também possuem limitações bastante consideráveis. Pedimos a eles que citassem algumas das limitações dos modelos que haviam construído e rapidamente eles começaram a citar algumas diferenças como, por exemplo, que o átomo segundo Dalton é indestrutível e o modelo deles é destrutível, que o átomo segundo Dalton é indivisível e o modelo deles é divisível e que segundo Dalton o átomo não pode ser visto e o deles podem.

Após revisarmos o modelo atômico de Dalton introduzimos o modelo atômico de Dalton modificado. Foram reproduzidos previamente em grande escala dois sistemas conceituais, um que trata da forma de apresentação da matéria segundo o modelo de Dalton e o outro que trata da forma de apresentação da matéria segundo o modelo de Dalton modificado (apêndices G e H). Esses sistemas conceituais e um kit molecular composto por hastes e bolinhas que permitem a representação de substâncias em nível atômico foram recursos auxiliadores na explicação desses conteúdos. Com o kit ilustramos substâncias simples e compostas de acordo com o modelo de Dalton e de acordo com o modelo de Dalton modificado.

Os alunos apresentaram um pouco mais de dificuldade para entender o modelo de Dalton modificado. Ficaram mais inibidos e tinham dificuldade para responder as perguntas que fazíamos para verificar se estavam compreendendo o conteúdo. Explicamos de diferentes maneiras a fim de sanar as dúvidas e percebemos que dentre todo o conteúdo a maior dificuldade foi entender o que seria o constituinte. Aqui o termo constituinte foi utilizado em referência ao trabalho de Tunes e colaboradores (1989) e nesse contexto representa um sinônimo de molécula. Em certo momento, enquanto explicávamos e utilizávamos os exemplos do $\mathrm{H}_{2}$ e do $\mathrm{O}_{2}$, uma aluna perguntou: "Dois (átomos) juntos formam um constituinte?". Quando respondemos que sim, que dois átomos de hidrogênio formavam o constituinte (molécula) $\mathrm{H}_{2}$, os alunos responderam quase que em um coral: "Ah, agora eu entendi, agora sim.”. Devido às dificuldades encontradas nesse momento do processo de 
ensino-aprendizagem, propusemos uma adaptação no sistema conceitual que faz referência ao modelo de Dalton modificado e a inserimos no módulo didático. Percebemos que por mais simples que pareça ser para quem já domina o conteúdo, a maior dificuldade estava em compreender a estrutura do constituinte (molécula), algo relativamente simples comparado a tudo o que estávamos explicando para tentar sanar as dúvidas. A partir desse momento a explicação seguiu de forma mais suave e a participação dos alunos aumentou consideravelmente.

Nesse dia, o barulho externo a sala estava altíssimo. Os alunos de outras turmas passavam próximo as janelas e a porta falando muito alto. Foi um barulho prolongado e às vezes era difícil ouvir a turma. Foi necessário manter um tom de voz mais alto que o normal durante a explicação.

Depois de concluída a explicação, pedimos aos alunos que construíssem modelos para substâncias simples e substâncias compostas de acordo com o modelo de Dalton modificado. Sugerimos que fossem representadas as substâncias hidrogênio, oxigênio e água. Aproveitamos esse momento para ressaltar que cada bolinha representa um átomo e que a representação deveria seguir uma proporção em relação ao número de átomos, já que na atividade anterior o número de átomos nas substâncias representadas foi aleatório.

O tempo, conforme já citamos, estava contado. Então, fizemos diferente do que havíamos feito na aula anterior, os alunos permaneceram sentados em fileiras e resolvemos não disponibilizar a massinha, que gerou tanta distração no encontro anterior. Alguns dos modelos construídos pelos alunos podem ser observados nas figuras 15 e 16 .
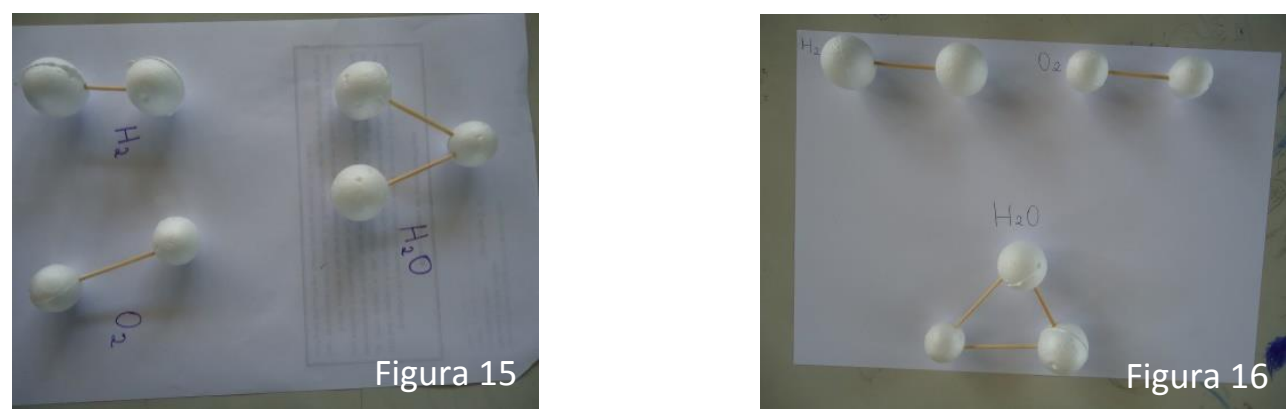

Figuras 15 e 16: Representação de substâncias simples e compostas segundo o modelo de Dalton modificado construída por um aluno.

A grande maioria dos modelos segue o padrão das figuras acima. Percebe-se que o número de átomos foi observado pelos alunos, porém a forma como eles se ligam não, o que já era esperado devido ao fato dessa parte do conteúdo não ter sido abordada. Conforme 
podemos observar em cada uma das imagens, as diferentes bolinhas (maiores e menores) representam as diferentes substâncias simples e o modelo com os dois tipos de bolinhas juntas representa a substância composta.

Em seguida, fizemos a leitura coletiva do texto 3 (apêndice I) intitulado "Modelo atômico de Dalton modificado", por nós elaborado, para reforçar o que havia sido explicado. Concluímos assim o conteúdo previsto para o segundo momento, que estava em atraso, e iniciamos as atividades previstas para o terceiro momento.

Iniciamos o terceiro momento fazendo um experimento para ilustrar a atração e repulsão entre corpos, chamado de "Atritando corpos". Utilizamos para a realização do experimento um balão e um canudo amarrado a uma linha. Pedimos a uma aluna voluntária que segurasse a linha com a qual o canudo estava amarrado enquanto a professora atritava o balão cheio de ar com os cabelos e logo em seguida o aproximava do canudo que se repelia do balão, conforme ilustrado na figura 17. Então perguntamos aos alunos porque o balão e o canudo estavam se repelindo. Os alunos se mostraram empolgados, as respostas foram várias, tais como: "É porque os dois têm a mesma matéria.", "As massas não são opostas." e "Os dois são positivos.". Pelas respostas acima descritas percebe-se que para eles a repulsão era causada por alguma propriedade que os dois objetos tinham em comum. Foi possível identificar que os alunos possuíam uma noção superficial sobre atração e repulsão de corpos, noção ainda insuficiente para dar prosseguimento a qualquer conteúdo que tivesse esse prérequisito. Analisando os dados, notamos que seria relevante a execução de um experimento que demonstrasse a atração entre os corpos, já que a atividade realizada demonstra apenas a repulsão entre esses. Portanto, inserimos ao módulo didático uma segunda atividade experimental referente à eletrização de corpos.

Em seguida, fizemos a leitura coletiva do texto 4 (apêndice J) intitulado "Descoberta dos elétrons", por nós elaborado, para auxiliar na apresentação e discussão do conteúdo que tratava das cargas elétricas com ênfase nos elétrons. Após essa abordagem perguntamos novamente aos alunos o porquê da repulsão entre o balão e o canudo e eles responderam quase que coletivamente: "Porque eles têm cargas iguais.", resposta satisfatória dentro desse contexto.

Finalizando o conteúdo, ligamos a esfera de raios conforme ilustrado na figura 18. Os alunos ficaram muito curiosos em relação aos efeitos da esfera e fizeram inúmeras perguntas relacionadas a isso. Quanto ao funcionamento da esfera, a mesma emite raios de luz de uma pequena esfera, localizada no centro, para as bordas da esfera maior. Quando tocamos a esfera 
externa os raios são direcionados ao ponto tocado gerando um efeito visual diferenciado. Os efeitos foram justificados devido à existência das cargas elétricas. Durante toda a explicação os alunos se mantiveram atentos.
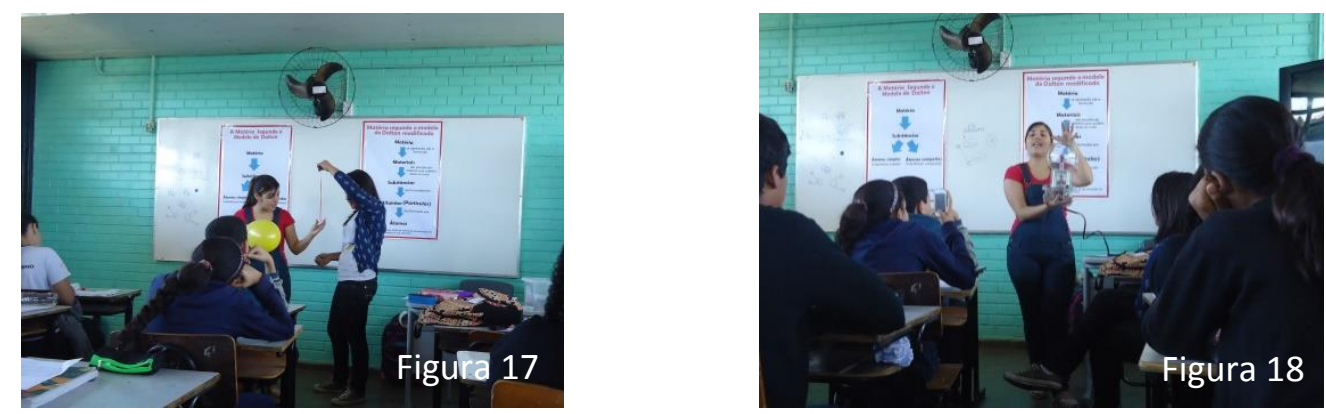

Figura 17: Momento da realização do experimento "Atritando corpos".

Figura 18: Momento da exposição da esfera de raios.

Os alunos queriam tocar na esfera, como já era esperado, e como as avaliações ainda precisavam ser preenchidas fizemos um combinado. $\mathrm{O}$ intervalo era no próximo tempo, então entregamos o questionário para que os alunos pudessem responder durante o tempo que ainda tínhamos de aula e ficamos a disposição durante todo o intervalo para que aqueles que tivessem interesse ficassem e manuseassem a esfera.

As duas avaliações, Avaliação da Aprendizagem 2 - AA2 (apêndice K), que não havia sido respondida durante o segundo momento porque não houve tempo suficiente para concluir o conteúdo, e Avaliação da Aprendizagem 3 - AA3 (apêndice L), foram entregues juntas para serem respondidas individualmente e devolvidas à pesquisadora ao final da aula.

Dos vinte e seis alunos presentes, vinte e um participaram do encontro anterior em que parte do conteúdo correspondente a AA2 havia sido abordado e cinco haviam faltado. Dos cinco que faltaram, um se recusou a responder a essa avaliação o que gerou um total de vinte e cinco atividades respondidas e analisadas. Quanto aos resultados da AA2, temos:

A questão 1 perguntava "Como Dalton descreve e representa o átomo? Descreva e ilustre.”. As descrições foram classificadas em oito categorias, conforme mostra a tabela 5 e as ilustrações foram classificadas em três categorias, conforme mostra a tabela 6: 
Tabela 5: Respostas da questão 1 (parte a) da Avaliação da Aprendizagem 2.

\begin{tabular}{|l|l|c|}
\hline \multicolumn{2}{|l|}{ Como Dalton descreve e representa o átomo? Descreva e ilustre. } \\
\hline A & Esférico & 16 \\
\hline B & Maciço & 16 \\
\hline C & Indivisível & 17 \\
\hline D & Indestrutível & 09 \\
\hline E & Pequeno & 03 \\
\hline F & Não é possível visualizá-lo & 02 \\
\hline G & Outras & 06 \\
\hline H & Não respondeu & 01 \\
\hline
\end{tabular}

Tabela 6: Respostas da questão 1 (parte b) da Avaliação da Aprendizagem 2.

\begin{tabular}{|c|l|c|}
\hline \multicolumn{2}{|c|}{ Como Dalton descreve e representa o átomo? Descreva e ilustre. } \\
\hline $\mathbf{I}$ & Desenho de uma esfera & 13 \\
\hline J & Outras & 04 \\
\hline K & Não respondeu & 08 \\
\hline
\end{tabular}

Como podemos ver na tabela 5, 16 alunos descrevem o átomo segundo Dalton como sendo esférico, 16 indicam que ele é maciço, para 17 alunos o átomo é indivisível, 09 o descrevem indestrutível, para 03 alunos o átomo é pequeno, 02 indicam que não é possível visualizá-lo, 06 respostas não correspondem a nenhuma das categorias acima e 01 aluno deixou a questão em branco. O número de respostas é superior ao número de questionários porque uma mesma resposta pode atender a mais de uma categoria dentre as listadas na tabela.

Com exceção das letras G (Outras) e H (Não respondeu) todas as demais categorias representam características do átomo de Dalton. O que significa que a grande maioria dos alunos consegue descrever de forma satisfatória o átomo segundo Dalton.

Já na tabela 6 vemos que, dentre os alunos que fizeram a ilustração, a maioria representou o átomo com o desenho de uma esfera, resposta aceita dentro desse contexto. Todas as quatro respostas que se encaixaram na categoria $\mathbf{J}$ (Outras) representaram as substâncias hidrogênio, oxigênio e água. As demais respostas, enquadradas na categoria $\mathrm{K}$ (Não respondeu), somam quase um terço do total de questionários, um número considerável. Na tabela 6 foi atribuída apenas uma categoria para cada ilustração.

A questão 2 perguntava "No que se refere à composição, o que diferencia as substâncias simples das substâncias compostas de acordo com o modelo de Dalton?". As respostas dissertativas foram classificadas em quatro categorias, conforme mostra a tabela 7 : 
Tabela 7: Respostas da questão 2 da Avaliação da Aprendizagem 2.

\begin{tabular}{|c|l|l|}
\hline \multicolumn{2}{|l|}{$\begin{array}{l}\text { No que se refere à composição, o que diferencia as substâncias simples das substâncias } \\
\text { compostas de acordo com o modelo de Dalton? }\end{array}$} \\
\hline A & $\begin{array}{l}\text { As substâncias simples possuem um tipo de átomo e as compostas possuem dois } \\
\text { tipos de átomos ou mais }\end{array}$ & 10 \\
\hline B & $\begin{array}{l}\text { As substâncias simples possuem um átomo e as compostas possuem dois átomos ou } \\
\text { mais }\end{array}$ & 06 \\
\hline C & A variedade dos átomos contidos nas substâncias & 01 \\
\hline D & Outras & 08 \\
\hline
\end{tabular}

Como podemos ver, 10 alunos diferenciam as substâncias simples das compostas de acordo com o modelo de Dalton dizendo que as substâncias simples possuem um tipo de átomo e as compostas possuem dois tipos de átomos ou mais, 06 diferenciam dizendo que as substâncias simples possuem um átomo e as compostas possuem dois átomos ou mais, 01 apenas indica que a diferença se dá pela variedade dos átomos contidos nas substâncias e 08 respostas não classificam em nenhuma das categorias acima. Para essa questão foi atribuída apenas uma categoria por resposta.

As letras A e C expressam respostas cientificamente aceitas, sendo que a letra A, além de representar as respostas mais completas, superou em números as demais categorias. $\mathrm{Na}$ letra C, apesar da resposta não especificar a característica de cada substância, simples e composta, indica no que ambas se diferenciam, na variedade de átomos. Já as letras B e D representam respostas não aceitas cientificamente. Percebe-se que as respostas classificadas na categoria A se diferenciam daquelas classificadas na categoria B apenas por uma palavra. Enquanto as da categoria A ressaltam que a diferença entre as substâncias está na variedade dos átomos, as da categoria B indicam que a diferença está no número de átomos. Diferença essa aparentemente sutil, porém determinante para o conceito.

A questão 3 perguntava "Em relação à constituição da matéria, no que o modelo de Dalton se difere do modelo de Dalton modificado por Avogadro?”. As respostas dissertativas foram classificadas em sete categorias, conforme mostra a tabela 8 : 
Tabela 8: Respostas da questão 3 da Avaliação da Aprendizagem 2.

\begin{tabular}{|l|l|c|}
\hline \multicolumn{2}{|l|}{$\begin{array}{l}\text { Em relação à constituição da matéria, no que o modelo de Dalton se difere do modelo de } \\
\text { Dalton modificado por Avogadro? }\end{array}$} \\
\hline A & $\begin{array}{l}\text { No modelo de Avogadro as substâncias são formadas por constituintes e estes são } \\
\text { formados por átomos }\end{array}$ & 02 \\
\hline B & Nos constituintes & 05 \\
\hline C & As substâncias são formadas por constituintes e estes são formados por átomos & 03 \\
\hline D & As substâncias são formadas diretamente por átomos & 02 \\
\hline E & Para Dalton o hidrogênio e oxigênio eram substâncias monoatômicas & 01 \\
\hline F & Outras & 10 \\
\hline G & Não respondeu & 02 \\
\hline
\end{tabular}

Conforme nos mostra a tabela acima, 02 alunos indicam a diferença entre o modelo de Dalton e o modelo de Dalton modificado dizendo que no modelo de Avogadro as substâncias são formadas por constituintes e estes são formados por átomos, 05 respostas apontam que a diferença está nos constituintes, 03 alunos responderam dizendo que as substâncias são formadas por constituintes e estes são formados por átomos, 02 disseram que as substâncias são formadas diretamente por átomos, 01 ressaltou que para Dalton o hidrogênio e oxigênio eram substâncias monoatômicas, 10 respostas não se encaixaram em nenhuma das categorias acima e 02 alunos não responderam a essa questão. Para essa questão foi atribuída apenas uma categoria por resposta.

Conforme já citamos, aqui o termo constituinte foi utilizado em referência ao trabalho de Tunes e colaboradores (1989), podendo ser entendido como molécula. Na letra A, as respostas descrevem parte da forma de apresentação da matéria segundo o modelo de Avogadro, que o diferencia do modelo de Dalton. É a categoria mais completa dentre as classificadas na tabela 8. Na letra B, foram classificadas respostas sucintas, essas indicam apenas que a diferença entre os modelos está nos constituintes (moléculas), mas são respostas aceitáveis dentro desse contexto. A letra $\mathrm{C}$ e a letra D representam respectivamente a descrição da forma de apresentação da matéria segundo o modelo de Avogadro e o modelo de Dalton, porém em nenhuma das respostas classificadas nessas duas categorias os alunos indicaram a qual modelo estavam se referindo, o que implica na classificação da resposta como aceitável ou não aceitável. E na letra E a resposta indica que para Dalton o hidrogênio e oxigênio eram substâncias monoatômicas, sem fazer referência à forma de apresentação da matéria. 
A questão 4 perguntava "O que seriam as partículas de acordo com essa modificação?". As respostas dissertativas foram classificadas em seis categorias, conforme mostra a tabela a seguir:

Tabela 9: Respostas da questão 4 da Avaliação da Aprendizagem 2.

\begin{tabular}{|l|l|l|}
\hline \multicolumn{2}{|c|}{ O que seriam as partículas de acordo com essa modificação? } \\
\hline A & A junção de dois átomos & 07 \\
\hline B & A junção de dois átomos ou mais & 01 \\
\hline C & É um conjunto de átomos que formam as substâncias & 01 \\
\hline D & $\mathrm{H}_{2}$ e $\mathrm{O}_{2}$ & 04 \\
\hline E & Outras & 11 \\
\hline F & Não respondeu & 01 \\
\hline
\end{tabular}

A tabela nos mostra que 07 respostas indicam que as partículas são a junção de dois átomos, 01 resposta se diferencia dessa por dizer que são a junção de dois átomos ou mais, 01 descreve as partículas como um conjunto de átomos que formam as substâncias, 04 dão como resposta $\mathrm{H}_{2}$ e $\mathrm{O}_{2}, 11$ respostas não classificam em nenhuma das categorias mencionados na tabela e 01 aluno não respondeu a essa questão. Para essa questão foi atribuída apenas uma categoria por resposta.

Percebe-se que a categoria A, apesar de não representar adequadamente o conceito de partícula, representa os exemplos de partículas que foram citados em aula $\left(\mathrm{H}_{2}\right.$ e $\left.\mathrm{O}_{2}\right)$. Dentro desse contexto as letras B e C respondem mais adequadamente a questão. Na letra D nota-se que os alunos, ao invés de conceituarem, citaram exemplos do que seriam as partículas de acordo com a modificação de Avogadro.

A questão 5 pedia "Reescreva o que você entende por modelo científico.". As respostas dissertativas foram classificadas em seis categorias, conforma mostra a tabela 10:

Tabela 10: Respostas da questão 5 da Avaliação da Aprendizagem 2.

\begin{tabular}{|l|l|l|}
\hline \multicolumn{2}{|c|}{ Reescreva o que você entende por modelo científico. } \\
\hline A & É uma representação parcial & 09 \\
\hline B & É uma representação parcial do que não se vê & 02 \\
\hline C & É semelhante ao modelado & 02 \\
\hline D & Pode ser modificado & 03 \\
\hline E & Outras & 09 \\
\hline F & Não respondeu & 02 \\
\hline
\end{tabular}


Como podemos ver, 09 respostas indicam que modelo científico é uma representação parcial, 02 indicam que é uma representação parcial do que não se vê, 02 fazem referência ao fato de ser semelhante ao modelado, 03 dizem que pode ser modificado, 09 respostas não classificam em nenhuma das categorias descritas na tabela acima e 02 alunos não responderam a essa questão. Para essa questão foi atribuída apenas uma categoria por resposta.

Fazendo-se uma comparação das respostas dadas a essa questão com as respostas dadas a questão 01 da AA1 que perguntava "O que são modelos científicos?" podemos perceber que o número de respostas que indicavam os modelos científicos como uma representação parcial do que não se vê caiu de dezesseis para duas respostas. Atribuímos esse resultado ao reforço dado a esse conceito no segundo momento, visando à correção de tal distorção conceitual. Com exceção dessa resposta e das letras E (Outras) e F (Não respondeu) as demais representam adequadamente o conceito de modelo científico discutido em sala.

Tendo concluído as analises da AA2, damos prosseguimento aos resultados e análises da AA3. Nessa aula estiveram presentes 26 alunos e todos responderam a essa atividade gerando um total de 26 avaliações analisadas. Quanto aos resultados da terceira avaliação, temos:

A questão 1 perguntava "Desde a antiguidade evidências da existência da eletricidade já eram observadas. Que evidências eram essas? Cite três exemplos.”. As respostas foram classificadas em cinco categorias, conforme mostra a tabela a seguir:

Tabela 11: Respostas da questão 1 da Avaliação da Aprendizagem 3.

Desde a antiguidade evidências da existência da eletricidade já eram observadas. Que evidências eram essas? Cite três exemplos.

\begin{tabular}{|l|l|l|}
\hline A & O âmbar quando atritado com a lã ficava carregado eletricamente & 11 \\
\hline B & Atração e repulsão entre corpos & 04 \\
\hline C & Repulsão entre o canudo e o balão & 02 \\
\hline D & Outras & 11 \\
\hline E & Não respondeu & 02 \\
\hline
\end{tabular}

Conforme nos mostra a tabela acima, 11 respostas citam como evidência da existência da eletricidade que o âmbar quando atritado com a lã ficava carregado eletricamente, 04 respostas citam a atração e repulsão entre corpos, 02 citam a repulsão entre o canudo e o balão, 11 respostas não classificam em nenhuma das categorias acima e 02 respostas ficaram 
em branco. O número de respostas é superior ao número de questionários porque uma mesma resposta pode atender a mais de uma categoria dentre as listadas na tabela.

As categorias representadas pelas letras A e B expressam respostas cientificamente aceitas. A letra A é mais específica quanto ao que se pede e a letra B é mais abrangente, mas ambas estão adequadas ao contexto do que foi pedido. A categoria $\mathrm{C}$ não representa evidências observadas na antiguidade, mas se trata do mesmo fenômeno, atração e repulsão de corpos, observado na experiência que foi realizada em sala. Nota-se também que nenhum aluno citou os três exemplos pedidos no final questão. Concordamos que esse comando tenha ficado um pouco vago, o que justificaria o fato dos alunos o terem ignorado. Decidimos então reestruturar a questão na proposição.

A questão 2 perguntava "O que são elétrons?". As respostas dissertativas foram divididas em seis categorias, conforme mostra a tabela 12:

Tabela 12: Respostas da questão 2 da Avaliação da Aprendizagem 3.

\begin{tabular}{|l|l|l|}
\hline \multicolumn{2}{|l|}{ O que são elétrons? } \\
\hline A & São cargas elétricas negativas & 14 \\
\hline B & São partículas menores que os átomos & 10 \\
\hline C & São partículas presentes nos átomos & 09 \\
\hline D & Contém carga elétrica & 01 \\
\hline E & Possuem carga positiva ou negativa & 02 \\
\hline F & Outras & 09 \\
\hline
\end{tabular}

Como podemos ver na tabela acima, 14 respostas conceituam os elétrons como cargas elétricas negativas, 10 dizem que são partículas menores que os átomos, 09 que os elétrons estão presentes nos átomos, 01 que eles possuem carga elétrica, 02 que possuem carga positiva ou negativa e 09 respostas não classificam em nenhuma das categorias anteriores. $\mathrm{O}$ número de respostas é superior ao número de questionários porque uma mesma resposta pode atender a mais de uma categoria dentre as listadas na tabela.

Com exceção das letras E (Possuem carga positiva ou negativa) e F (Outras), que são minoria, todas as demais respostas representam características dos elétrons que foram discutidas durante as aulas, o que significa que a maior parte dos alunos respondeu a questão de forma satisfatória. Concluídas as análises da AA3, damos prosseguimento com os relatos do quarto momento. 


\subsubsection{Quarto Momento}

Aula ministrada no dia 26 de agosto de 2014 das 7h00min às 8h35min. Estiveram presentes nessa aula 35 alunos de um total de 36.

Do terceiro para o quarto momento as intervenções tiveram uma semana de intervalo devido à participação da escola no Circuito de Ciências, evento anual da Secretaria de Educação do Distrito Federal (SEDF) no qual a escola costuma expor trabalhos. Iniciamos a aula do quarto momento fazendo um lanche com a turma, mas não um lanche qualquer. Providenciamos intencionalmente bolo formigueiro e suco em quantidade suficiente para todos e tomamos café da manhã juntos.

Após o lanche e de forma descontraída retomamos alguns importantes conceitos já vistos sobre o átomo. Relembramos o que seria o átomo para Demócrito e Leucipo e o modelo atômico de Dalton para então abordamos o modelo atômico de Thomson. Após a explicação desse novo modelo e das descobertas que fizeram Thomson e sua equipe chegar até ele discutimos e analisamos coletivamente algumas limitações e diferenças do modelo de Dalton para esse. Uma aluna durante a discussão disse: "Se tem elétrons não é maciço.". Os alunos foram participativos e por meio de suas expressões foi possível perceber o alcance dos objetivos da aula. Aproveitamos o momento para discutir também as razões que poderiam levar um modelo a ser modificado ou substituído.

Em seguida, abordamos o conceito de analogia citando algumas de suas vantagens e desvantagens a fim de utilizar uma analogia em classe sem que essa provocasse distorções conceituais do fenômeno apresentado. Durante a explicação induzimos ao máximo a participação dos alunos por meio de perguntas direcionadas a eles, perguntamos inclusive se poderiam nos dar exemplos de analogias e uma aluna citou a analogia de um abacate em comparação com uma célula em que a casca do abacate seria a membrana plasmática, a massa da fruta seria o citoplasma e o caroço seria o núcleo da célula. Aproveitamos esse exemplo e pedimos para que eles ressaltassem nessa analogia quais eram as semelhanças e diferenças que eles podiam observar nessa relação analógica e por meio de suas falas podemos perceber que haviam compreendido o conceito e as limitações dessa ferramenta.

Então, tendo discutido o conceito em questão, fizemos a analogia do modelo atômico de Thomson com o bolo formigueiro que havia sido servido no lanche no início da aula. $\mathrm{O}$ bolo formigueiro é composto por uma massa branca recheada com chocolate granulado, 
conforme podemos ver na figura 19. Nessa analogia a massa branca do bolo representa a massa do átomo carregada positivamente e os granulados do bolo representam os elétrons incrustados. Os alunos identificaram cada elemento do modelo atômico de Thomson no bolo, porém ressaltamos também as diferenças entre os fenômenos comparados.

Em seguida, fizemos a leitura e discussão do texto 5 (apêndice M) intitulado "Modelo atômico de Thomson", por nós elaborado, que reforçou a explicação.

Após ter concluído toda a explicação pedimos para os alunos construírem com o material que foi disponibilizado (massinha de modelar, miçangas e folha branca) modelos para o átomo de Thomson. Mais uma vez, antes de iniciar as atividades, pedimos aos alunos que se concentrassem em modelar com a massinha apenas o modelo do átomo. Alguns modelos construídos pelos alunos podem ser observados nas figuras 20, 21 e 22 .
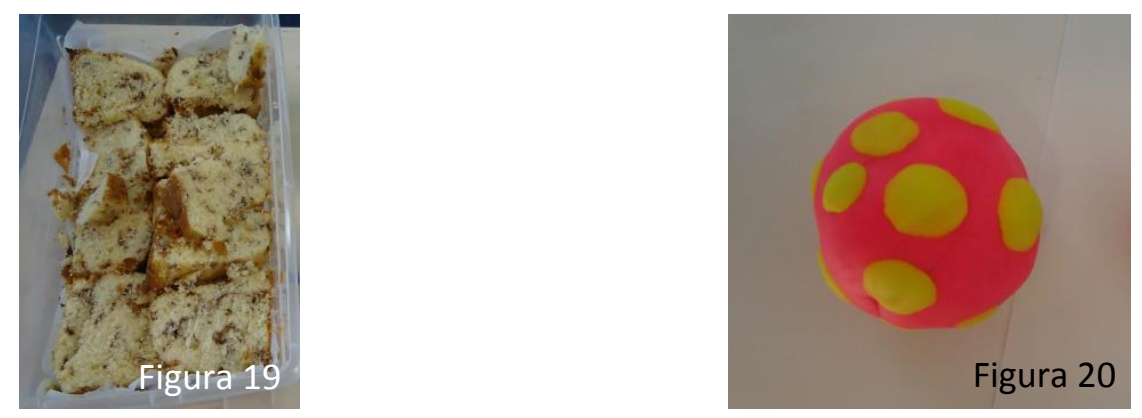

Figura 19: Bolo servido no início da aula.
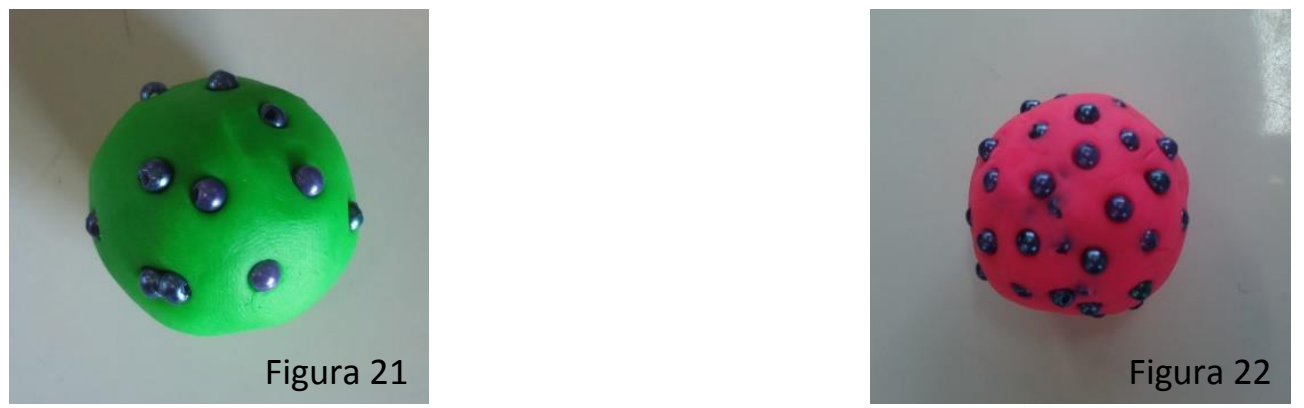

Figuras 20, 21 e 22: Representação do átomo de Thomson construída por um aluno.

A aula foi muito tranquila. A quantidade de conteúdo abordado foi pequena comparada às outras aulas. Os alunos tiveram mais tempo para construírem os modelos e para responderem a Avaliação da Aprendizagem 4 - AA4 (apêndice N) que foi entregue logo em seguida para que eles respondessem individualmente e entregassem a pesquisadora ao final da aula. Quanto aos resultados dessa avaliação, temos: 
A questão 1 perguntava "No que o modelo atômico de Thomson se difere do modelo atômico de Dalton?". As respostas dissertativas foram classificadas em sete categorias para facilitar as análises, conforme mostra a tabela 13:

Tabela 13: Respostas da questão 1 da Avaliação da Aprendizagem 4.

\begin{tabular}{|l|l|l|}
\hline \multicolumn{2}{|l|}{ No que o modelo atômico de Thomson se difere do modelo atômico de Dalton? } \\
\hline A & O modelo atômico de Thomson é divisível & 10 \\
\hline B & O modelo atômico de Dalton é indivisível & 08 \\
\hline C & $\begin{array}{l}\text { O átomo segundo Thomson é uma esfera carregada positivamente com partículas } \\
\text { negativas incrustadas }\end{array}$ & 15 \\
\hline D & O átomo segundo Dalton é esférico, maciço, indivisível e indestrutível & 05 \\
\hline E & Nos elétrons & 05 \\
\hline F & O modelo atômico de Thomson contém elétrons & 05 \\
\hline G & Outras & 03 \\
\hline
\end{tabular}

Como podemos ver, 10 respostas diferenciam os modelos atômicos de Thomson e Dalton indicando que o modelo atômico de Thomson é divisível, 08 diferenciam dizendo que o modelo atômico de Dalton é indivisível, 15 diferenciam os modelos dizendo que o átomo segundo Thomson é uma esfera carregada positivamente com partículas negativas incrustadas, 05 o fazem descrevendo o átomo segundo Dalton como esférico, maciço, indivisível e indestrutível, 05 indicam apenas que a diferença está nos elétrons, 05 especificam que o modelo atômico de Thomson contém elétrons e 03 respostas não classificam em nenhuma das categorias anteriores. O número de respostas é superior ao número de questionários porque uma mesma resposta pode atender a mais de uma categoria dentre as listadas na tabela.

Todas as respostas, com exceção da letra G (Outras), estão adequadas ao que se pede e são respostas aceitas dentro desse contexto. As letras A e B fazem referência a apenas um aspecto dos modelos, a divisibilidade, porém um aspecto relevante e enfatizado na abordagem desse conteúdo. As letras C e D fazem uma descrição do átomo segundo Thomson e segundo Dalton respectivamente, sendo que as respostas que descrevem o átomo segundo Thomson superam em números todas as demais. A letra $\mathrm{E}$ apenas indica que a diferença está nos elétrons, mas sem identificar em qual modelo eles se encontram, diferentemente da letra F que especifica que os elétrons são parte do modelo de Thomson. Duas entre as três respostas que se classificaram na categoria G (Outras) indicaram o átomo de Thomson como uma esfera cheia de bolinhas, nota-se que as respostas são uma descrição do modelo construído por eles. 
É possível perceber por meio das respostas dadas a essa questão que os alunos adquiriram capacidade de descrever e comparar os modelos estudados até aqui.

A questão 2 perguntava "De acordo com o modelo atômico de Thomson, como os elétrons estão distribuídos nos átomos?”. As respostas dissertativas foram classificadas em oito categorias, conforme mostra a tabela 14 :

Tabela 14: Respostas da questão 2 da Avaliação da Aprendizagem 4.

\begin{tabular}{|l|l|l|}
\hline \multicolumn{2}{|l|}{$\begin{array}{l}\text { De acordo com o modelo atômico de Thomson, como os elétrons estão distribuídos nos } \\
\text { átomos? }\end{array}$} \\
\hline A & Estão incrustados nos átomos & 12 \\
\hline B & Estão dentro dos átomos & 07 \\
\hline C & Estão dentro e fora dos átomos & 01 \\
\hline D & Estão espalhados pelos átomos & 01 \\
\hline E & Estão fixados nos átomos & 02 \\
\hline F & Estão no núcleo dos átomos & 02 \\
\hline G & O átomo é uma esfera carregada positivamente com partículas negativas incrustadas & 03 \\
\hline H & Outras & 07 \\
\hline
\end{tabular}

Conforme nos mostra a tabela, 12 alunos responderam que os elétrons estão incrustados nos átomos, 07 responderam que estão dentro dos átomos, 01 respondeu que está dentro e fora, 01 respondeu que eles estão espalhados pelos átomos, 02 que os elétrons estão fixados nos átomos, 02 responderam que estão no núcleo, 03 responderam que o átomo é uma esfera carregada positivamente com partículas negativas incrustadas e 07 respostas não classificaram em nenhuma das categorias descritos acima. Para essa questão foi atribuída apenas uma categoria por resposta.

O termo cientificamente mais utilizado para descrever a disposição dos elétrons no modelo atômico de Thomson é incrustado, geralmente encontra-se descrito que os elétrons estão incrustados na esfera carregada positivamente, e esse foi o termo mais utilizado pelos alunos para descreverem como os elétrons estão distribuídos nos átomos (categoria A). Nas categorias B, C, D e E os alunos utilizam outros termos, mas com suas próprias palavras, de alguma forma, identificam os elétrons na estrutura do átomo. Já a letra $\mathrm{F}$ chama atenção pelo fato dos alunos citarem uma estrutura que ainda não foi abordada em sala e que Thomson não identifica em seu modelo, o núcleo. Na letra $G$ percebe-se uma clara descrição do modelo 
atômico de Thomson e na letra H (Outras), ao invés de responderem ao que se pede, a maior parte dos alunos respondeu dando uma definição para elétron.

A questão 3 pedia "Reescreva o que você entende por elétron.". As respostas dissertativas foram classificadas em cinco categorias, conforme mostra a tabela a seguir:

Tabela 15: Respostas da questão 3 da Avaliação da Aprendizagem 4.

\begin{tabular}{|l|l|l|}
\hline \multicolumn{2}{|c|}{ Reescreva o que você entende por elétron. } \\
\hline A & São partículas negativas & 10 \\
\hline B & São partículas negativas nos átomos & 07 \\
\hline C & São partículas menores que o átomo & 01 \\
\hline D & São partículas incrustadas nos átomos & 01 \\
\hline E & Outras & 16 \\
\hline
\end{tabular}

Como podemos ver, 10 alunos descrevem os elétrons como partículas negativas, 07 o descrevem como partículas negativas nos átomos, 01 indica que são partículas menores que o átomo, 01 que são partículas incrustadas nos átomos e 16 respostas não classificam em nenhuma das categorias anteriores. Para essa questão foi atribuída apenas uma categoria por resposta.

Com exceção da letra E (Outras) as demais respostas descrevem aspectos dos elétrons discutidos em sala e aceitáveis dentro desse contexto, sendo que as categorias B e D indicam que os elétrons se encontram na estrutura do átomo. O número de respostas que se classificaram na categoria $\mathrm{E}$ representa quase metade do número de respostas, um valor muito significativo, pincipalmente se tratando de respostas não aceitáveis no contexto em que foram analisadas. Fazendo-se uma comparação da questão 2 da AA3 que perguntava "O que são elétrons?" com essa questão, as respostas não aceitáveis subiram de nove para dezesseis. A maior parte dessas respostas faz uma descrição do átomo de Thomson ou tentam descrever a atração e repulsão de cargas elétricas. Percebe-se uma má interpretação do enunciado da questão, que pode estar entre as causas do aumento do número de respostas não aceitáveis. Tendo concluído as análises da AA4, partiremos aos relatos do quinto momento. 


\subsubsection{Quinto Momento}

Aula ministrada no dia 29 de agosto de 2014 das 8 h35min às $10 \mathrm{~h} 05 \mathrm{~min}$. Estiveram presentes nessa aula 32 alunos de um total de 36.

Mais uma vez iniciamos a aula retomando os principais conceitos já abordados a fim de reforçá-los. Em seguida, para introduzir o modelo atômico e Rutherford, foi utilizado um vídeo $^{2}$ de aproximadamente dois minutos, que explica e demonstra o experimento de Rutherford com partículas alfa e em seguida o novo modelo proposto por ele. O vídeo foi exibido três vezes. Fizemos a primeira exibição sem explicações previas e sem interrupção. Quando o vídeo terminou perguntamos aos alunos o que haviam entendido, com uma cara de espanto a maioria deles respondeu que não tinha entendido nada. Foi perceptível a preocupação deles com a complexidade aparente do conteúdo, mas após a explicação as expressões mudaram bastante. Exibimos uma segunda vez, mas agora fazendo pausas e explicando cada etapa do experimento, seus resultados e as deduções feitas por Rutherford. Os alunos acompanharam todo o processo de forma participativa. Então o vídeo foi exibido uma terceira vez após a explicação, sem interrupções, e os alunos pareceram ter compreendido bem o conteúdo, fato que será constatado a seguir na análise das avaliações.

Em seguida, discutimos coletivamente o avanço do modelo de Thomson para este valorizando o aspecto da ciência mutável e inacabada. A discussão foi um pouco extensa, mas os alunos participaram continuamente e corresponderam bem às perguntas direcionadas a eles.

Após esse momento, fizemos a leitura coletiva do texto 6 (apêndices $\mathrm{O}$ e P) por nós elaborado e intitulado "Modelo atômico de Rutherford". As dúvidas após a leitura foram poucas, atribuímos isso ao fato do conteúdo ter sido por completo explicado previamente, durante a apresentação do vídeo.

Iniciamos em seguida a realização de alguns experimentos a fim de reforçar o conteúdo. Os experimentos foram demonstrativos e realizados de modo que toda a turma pudesse ver. Foram experimentos simples, sem custo significativo e que podem ser realizados em sala de aula sem oferecer riscos. Cada um deles veio seguido de discussão e explicação. $\mathrm{O}$ primeiro consistiu em colocar uma porção de sal na água e misturar. O volume de água,

\footnotetext{
${ }^{2}$ SISDEAPUCARANA. Aula 1 vídeo complementar teoria atômica experimento de Rutherford.
} Disponível em: <http://www.youtube.com/watch?v=CRU1ltJs2SQ>. Acesso em: 27 de maio de 2014. 
verificado em um copo medidor, aparentemente não mudou. Quando perguntamos aos alunos porque o volume da água não aumentou depois de adicionarmos o sal obtivemos algumas respostas, tais como: "Porque o sal se misturou." e "Porque o sal se dissolveu na água.". Então perguntamos onde estaria o sal e muitos responderam simplesmente "Na água.". Perguntamos novamente: Se está na água, porque o volume não aumentou? E uma aluna respondeu: “É porque o sal tem partículas pequenas.". Mas nós continuamos insistindo e fazendo perguntas até que um aluno respondeu: "Tá entre os espaços dos átomos da água.". Após essa resposta outras como "Tá nos espaços vazios." e "Tá na eletrosfera." foram surgindo. O tempo investido na discussão foi muito relevante para que os próprios alunos pudessem chegar a uma justificativa aceitável para o resultado do experimento. Muito provavelmente os alunos não teriam a mesma compreensão se a explicação fosse apenas expositiva, sem a indução de uma discussão que os levasse a pensar a respeito.

Concluímos a explicação desse primeiro experimento realizando outro experimento com feijão, açúcar e água que seria uma analogia do que aconteceu com o sal na água no primeiro experimento (lembramos que o conceito de analogia já foi discutido com os alunos anteriormente). $\mathrm{O}$ experimento consistiu em preencher um copo de vidro com grãos de feijão. Em seguida, perguntamos aos alunos se ainda havia espaços vazios no recipiente. Depois, acrescentamos uma porção de açúcar que preencheu os espaços entre os grãos de feijão. Perguntamos novamente se ainda havia espaços vazios a serem preenchidos. Acrescentamos ainda água ao recipiente e novamente perguntamos se ainda havia espaços vazios no copo. Desde o início do experimento os alunos já sugeriram a existência dos espaços vazios.

Comparamos esse experimento com o anterior fazendo uma analogia em que o feijão desse experimento representaria a água do primeiro experimento e o açúcar representaria o sal. Em ambos os casos o segundo componente foi acrescentado ao recipiente sem que o volume inicial fosse alterado. Nesse experimento, diferentemente do primeiro, era possível visualizar os espaços vazios entre os componentes que foram adicionados ao recipiente até que ele fosse preenchido por água. A intensão foi que os alunos percebessem a existência de espaços vazios entre as moléculas de água. A participação dos alunos nos leva a crer que tal objetivo tenha sido alcançado. Momentos da realização desses dois experimentos podem ser observados nas figuras 23 e 24.

Realizamos na sequência um terceiro experimento. Esse consiste em colocar um balão vazio na boca de uma garrafa pet de forma que ela fique lacrada. Quando a garrafa é aquecida por um secador de cabelo o balão se enche. Ressaltamos que em cada experimento realizado 
primeiramente os alunos faziam suposições em relação aos resultados para que a partir de tais suposições desenvolvêssemos a explicação, sempre incentivando a participação deles. Sendo assim, perguntamos aos alunos porque o balão encheu quando a garrafa foi aquecida. Uma aluna respondeu que "O ar quente fica em cima e o ar frio fica embaixo.", supondo que o ar quente estaria preenchendo o balão, que nesse momento estava voltado para cima. Então realizamos novamente o experimento, mas agora com a garrafa de cabeça para baixo. O balão encheu do mesmo jeito. Perguntamos novamente porque o balão encheu e obtivemos as mais diversas respostas, tais como: "Porque aumentou a densidade do ar.", "Os átomos se agitam mais quando estão quentes.", "Os espaços deles foram diminuindo.", "Porque o calor fez os átomos ficarem mais longe um do outro." e "Preencheu um espaço maior sem aumentar a massa. ”, querendo dizer que os átomos não cresceram, apenas se afastaram um do outro.

Durante a explicação repassamos as respostas discutindo cada uma delas, reconstruindo as que não faziam sentido e reafirmando as aceitáveis. Ficou concluído então que o balão se encheu porque as moléculas aos serem aquecidas se afastaram umas das outras ocupando um volume maior. Citamos o termômetro analógico para exemplificar um fenômeno semelhante em líquido. Nota-se aqui a necessidade de diferenciar com os alunos espaços vazios entre os átomos e espaços vazios entre as moléculas. Um momento da realização desse experimento pode ser observado na figura 25.
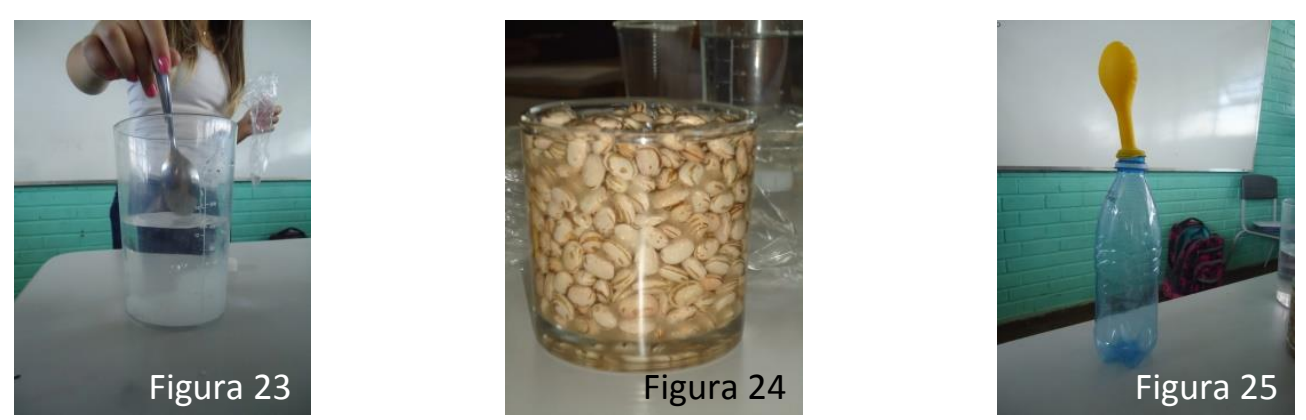

Figura 23: Realização do primeiro experimento.

Figura 24: Realização do segundo experimento.

Figura 25: Realização do terceiro experimento.

Após concluir a explicação dos experimentos disponibilizamos materiais para que os alunos construíssem individualmente modelos para o átomo de Rutherford. Durante a construção percebemos que alguns alunos estavam modelando o experimento com partículas alfa, então chamamos atenção e redirecionamos a modelagem para o átomo de Rutherford. Os modelos foram os mais variados. Alguns dos modelos construídos pelos alunos podem ser observados nas figuras de 26 a 31 . 

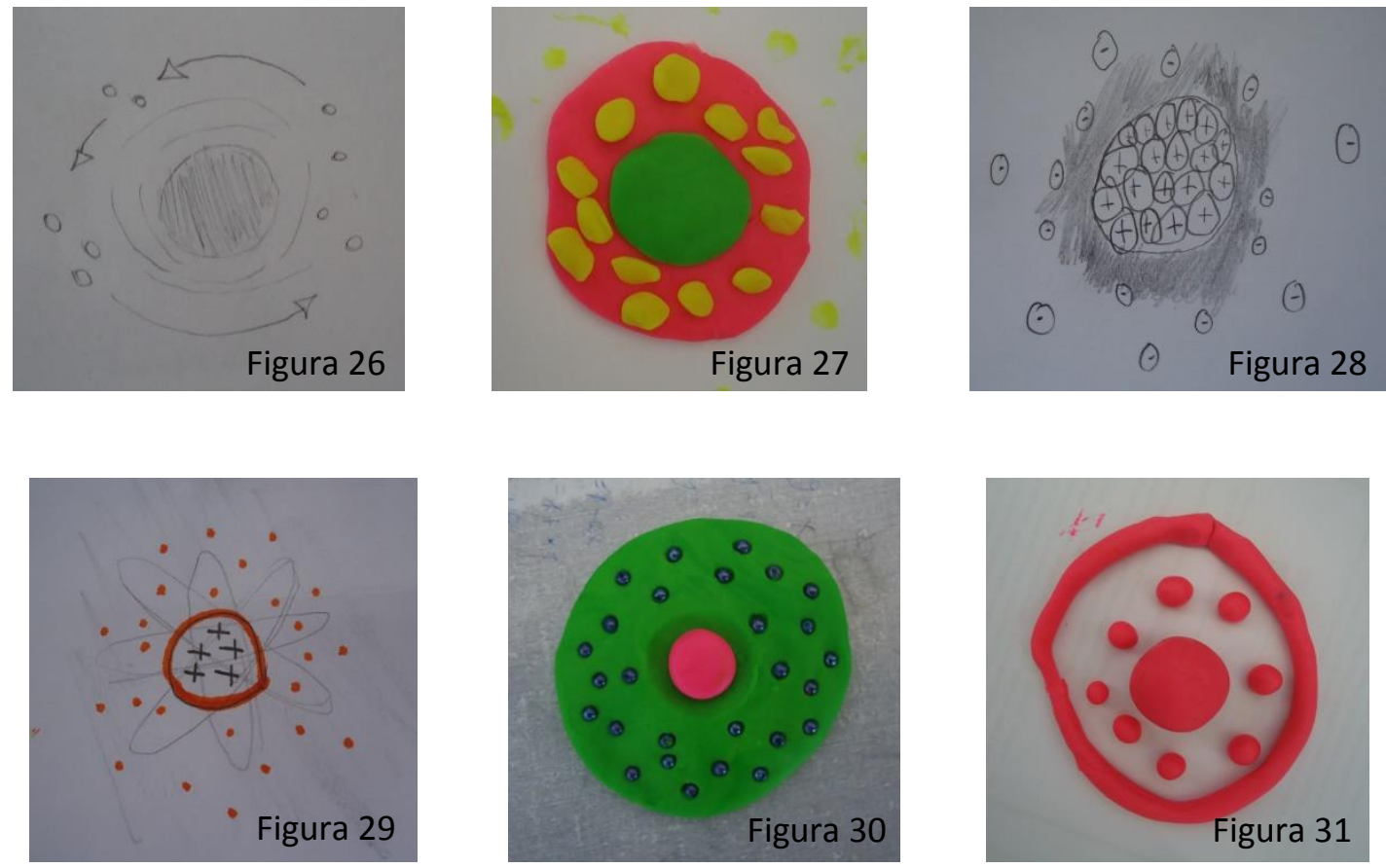

Figuras 26, 27, 28, 29, 30 e 31: Representação do átomo de Rutherford construída por um aluno.

Pode-se observar que apesar das variações todas as imagens possuem estruturas em comum, como uma estrutura central que representa o núcleo do átomo, sinais de mais na região do núcleo das figuras 28 e 29 que indicam a presença de carga positiva, uma estrutura ao redor do núcleo que representa a eletrosfera e alguns pontos nessa região que representam os elétrons. Na figura 28 há nesses pontos um sinal de menos indicando a carga negativa dos elétrons. Pode-se observar também que na figura 26 há setas que indicam que os elétrons estão em movimento orbital ao redor do núcleo. Já na figura 29 há uma estrutura muito comum na representação do átomo em livros didáticos que geralmente representam as órbitas dos elétrons, mas que em momento algum durante a intervenção foi exposta, sugerindo que o aluno tenha tido acesso em outro momento. As demais representações, de modo geral, possuem essas estruturas sendo consideradas representações aceitáveis dentro desse contexto.

Em seguida, entregamos a Avaliação da Aprendizagem 5 - AA5 (apêndice Q) para ser preenchida individualmente e entregue a pesquisadora ao final da aula. O próximo tempo era intervalo e percebemos que grande parte da turma estava respondendo a avaliação com muita pressa para sair logo. Nesse momento chamamos a atenção de todos, explicamos a importância da avaliação e devolvemos todas para que reavaliassem as respostas e alterassem alguma caso achassem necessário. Não sabemos se surtiu efeito, pois todas as atividades foram entregues de volta muito rápido. Era perceptível o descaso de parte da turma ao 
responderem as avaliações visto que elas não compunham a nota bimestral da disciplina. Quanto aos resultados da AA5, temos:

A questão 1 perguntava “Quais são as características do modelo atômico proposto por Rutherford que se diferenciam do modelo atômico de Thomson?". As respostas dissertativas foram classificadas em oito categorias, conforme mostra a tabela abaixo:

Tabela 16: Respostas da questão 1 da Avaliação da Aprendizagem 5.

\begin{tabular}{|l|l|c|}
\hline \multicolumn{2}{|l|}{$\begin{array}{l}\text { Quais são as características do modelo atômico proposto por Rutherford que se } \\
\text { diferenciam do modelo atômico de Thomson? }\end{array}$} \\
\hline A & $\begin{array}{l}\text { O modelo atômico de Rutherford não é uma esfera carregada positivamente com } \\
\text { elétrons incrustados }\end{array}$ & 09 \\
\hline B & O átomo segundo Rutherford possui uma pequena região mais densa, o núcleo & 12 \\
\hline C & O átomo segundo Rutherford possui um pequeno núcleo com carga positiva & 05 \\
\hline D & O átomo segundo Rutherford possui elétrons girando em órbitas ao redor do núcleo & 06 \\
\hline E & O átomo segundo Rutherford possui uma região chamada eletrosfera & 10 \\
\hline F & O átomo segundo Rutherford possui espaços vazios & 08 \\
\hline G & Núcleo e eletrosfera & 02 \\
\hline H & Outras & 06 \\
\hline
\end{tabular}

Como podemos ver, 09 respostas diferenciam o modelo atômico de Rutherford do modelo de Thomson dizendo que o modelo atômico de Rutherford não é uma esfera carregada positivamente com elétrons incrustados, 12 respostas descrevem que o átomo segundo Rutherford possui uma pequena região mais densa, o núcleo, 05 respostas o descrevem dizendo que possui um pequeno núcleo com carga positiva, 06 respostas dizem que o átomo segundo Rutherford possui elétrons girando em órbitas ao redor do núcleo, 10 respostas o descrevem dizendo que possui uma região chamada eletrosfera, 08 dizem que ele possui espaços vazios, 02 dão como resposta apenas núcleo e eletrosfera e 06 respostas não classificam em nenhuma das categorias anteriores. O número de respostas é superior ao número de questionários porque uma mesma resposta pode atender a mais de uma categoria dentre as listadas na tabela.

Podemos observar que na categoria A há uma clara descrição do modelo atômico de Thomson e uma negação de que esse modelo seja igual ao de Rutherford. Tais respostas aparecem nos questionários apenas com essa informação ou seguidas de características do modelo de Rutherford. Esse segundo modelo de resposta é muito interessante, pois dele podemos deduzir que os alunos são capazes de descrever ambos os modelos e compará-los. 
As categorias B, C, D, E e F descrevem características do modelo atômico de Rutherford ressaltando cada um deles aspectos diferentes, mas todos cientificamente aceitáveis. A categoria $\mathrm{G}$ representa respostas sucintas. As respostas indicam o núcleo e a eletrosfera como diferença entre os modelos, mas sem indicar a qual modelo tais estruturas pertencem. E a categoria H (Outras) representa respostas não aceitas ou não adequadas ao que se pede, como a descrição do experimento, por exemplo.

A questão 2 perguntava "Como Rutherford concluiu que a maior parte do átomo é formada por espaços vazios?". As respostas dissertativas foram classificadas em três categorias, conforme mostra a tabela 17:

Tabela 17: Respostas da questão 2 da Avaliação da Aprendizagem 5.

Como Rutherford concluiu que a maior parte do átomo é formada por espaços vazios?

\begin{tabular}{|l|l|l|}
\hline A & Observou que a maior parte das partículas alfa atravessou a lâmina de ouro & 17 \\
\hline B & Realizou um experimento com partículas alfa & 07 \\
\hline C & Outras & 08 \\
\hline
\end{tabular}

Como podemos ver, 17 alunos afirmaram que Rutherford concluiu que a maior parte do átomo é formada por espaços vazios observando em seu experimento que a maior parte das partículas alfa atravessou a lâmina de ouro, 07 afirmam que ele chegou a essa conclusão realizando um experimento com partículas alfa e 08 respostas não se encaixam nas categorias anteriores. Para essa questão foi atribuída apenas uma categoria por resposta.

É possível perceber na categoria A que a maior parte dos alunos respondeu a questão da forma mais adequada, identificando o que foi observado por Rutherford para se chegar à conclusão dos espaços vazios. Já nas respostas representadas pela categoria B os alunos identificaram apenas o experimento realizado por ele. E as respostas classificadas na categoria C representam as não aceitáveis ou inadequadas ao que se pede, como aquelas que descrevem outras observações feias por Rutherford em relação ao experimento com partículas alfa. Tendo concluído as análises da AA5, partiremos aos relatos do sexto momento. 


\subsubsection{Sexto Momento}

Aula ministrada no dia 02 de setembro de 2014 das 7 h00min às $8 \mathrm{~h} 35 \mathrm{~min}$. Estiveram presentes nessa aula 27 alunos de um total de 36.

Esse era o primeiro horário do dia e à medida que os alunos iam chegando eram diretamente encaminhados para o laboratório da escola para a realização de um experimento que havia sido previamente preparado. O experimento realizado foi o "Teste de chamas"3. Optamos por realizá-lo apenas de forma demonstrativa pelos riscos que pode oferecer, principalmente se tratando de alunos do Ensino Fundamental. Mas, apesar disso, é um experimento que pode ser realizado na própria sala de aula. Optamos pelo laboratório apenas por se tratar de um ambiente mais escuro, com cortinas, que permitiria melhor visualizar a cor das chamas, ao contrário da sala de aula que é um ambiente muito claro.

$\mathrm{O}$ experimento consistiu em colocar cinco substâncias diferentes $\left(\mathrm{CaCl}_{2}\right.$, $\mathrm{CuSO}_{4} \cdot 5 \mathrm{H}_{2} \mathrm{O}, \mathrm{LiCl}, \mathrm{NaCl}$ e $\left.\mathrm{SrCl}_{2} \cdot 6 \mathrm{H}_{2} \mathrm{O}\right)$ em cinco recipientes e provocar a combustão utilizando de preferência metanol. As chamas apresentam cores diferentes em cada substância. Momentos da realização do experimento podem ser observados nas figuras 32 e 33. Realizamos o experimento duas vezes. Na primeira vez todas as substâncias foram aquecidas ao mesmo tempo. Na segunda vez as aquecemos uma por vez. Os alunos perceberam e identificaram facilmente a cor das chamas, então perguntamos por que cada substância gerou uma cor de chama diferente ao ser aquecida. A primeira resposta foi " $E$ por causa da cor das substâncias. ”. Fazendo uma análise eles mesmos perceberam que quatro das substâncias eram brancas e descartaram essa hipótese. Tornamos a fazer a mesma pergunta e outro aluno respondeu: "Por causa do combustivel.". E novamente a hipótese foi descartada ao mencionarem que o combustível utilizado foi o mesmo em todas as substâncias. Outro aluno, incluindo o átomo em sua resposta, disse: "Conforme muda o tamanho do átomo muda a cor.". Mas a turma não chegou a uma conclusão em comum.

\footnotetext{
${ }^{3} \mathrm{O}$ Teste de chamas consiste no aquecimento de diferentes substâncias por meio da queima de um combustível adicionado (nesse caso, metanol), sendo que as chamas geradas em cada substância apresentam cores diferentes. A justificativa se dá pelo fato dos elétrons dos átomos de cada substância serem elevados a um nível de energia mais externo ao serem submetidos ao calor. Entretanto, tais elétrons possuem tendência de retornar à sua posição de origem e quando isso acontece liberam energia sob a forma de luz, sendo essa de diferentes cores dependendo do nível de energia que os elétrons se encontram.
} 

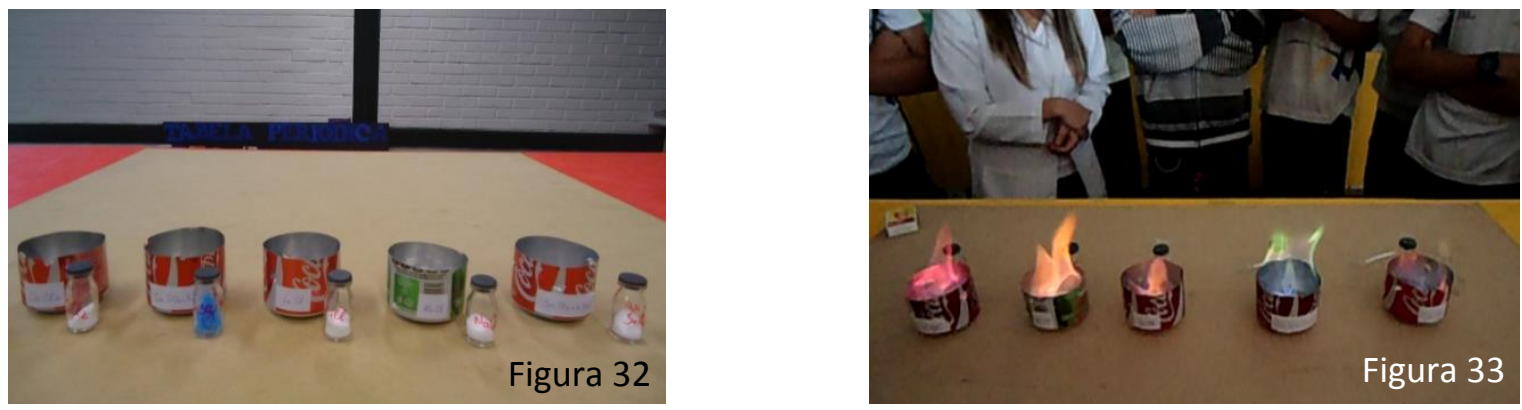

Figuras 32 e 33: Realização do "Teste de chamas".

Antes de iniciarmos a explicação do experimento relembramos os modelos atômicos de Dalton, Thomson e Rutherford. A partir dessa revisão entramos na explicação do modelo atômico de Bohr discutindo as limitações do modelo de Rutherford e as alterações feitas por Bohr nesse modelo. Ainda no laboratório discutimos os resultados do experimento atribuindo as diferentes cores das chamas aos níveis de energia proposto por Bohr. Os alunos pareciam um pouco confusos em relação ao conteúdo, então nesse momento encaminhamos a turma para a sala de aula para continuar a explicação com o auxílio de outros recursos.

Fizemos nesse momento a leitura do texto 7 (apêndice R), por nós elaborado, intitulado "Modelo atômico de Rutherford-Bohr" e prosseguimos a explicação discutindo aspectos importantes citados no texto. Nesse momento a participação dos alunos aumentou de forma considerável, o que nos leva a deduzir que o texto foi um recurso auxiliador relevante para a explicação desse conteúdo.

O período de explicação foi extenso, os alunos fizeram muitas perguntas e o professor regente, inclusive, fez algumas complementações avançando com o conteúdo até a distribuição dos elétrons por camada, que não estava previsto na nossa proposição.

Distribuímos depois de concluída toda a explicação a Avaliação da Aprendizagem 6 AA6 (apêndices S e T) para ser respondida individualmente e entregue a pesquisadora ao final da aula dando aos alunos um pouco mais de tempo para responder pelo fato dessa avaliação ser maior. Nas aulas anteriores, antes de responderem a avaliação, os alunos construíram modelos para os átomos de Dalton, Thomson e Rutherford, mas como a AA6 é mais extensa e já pede para os alunos ilustrarem tal modelo na questão 4, não requisitamos que o fizessem antes.

Uma aluna em especial, que geralmente é muito participativa, teve seria dificuldade para compreender esse conteúdo no momento da explicação coletiva. Quando verificamos a frequência percebemos que ela havia faltado à aula anterior. Nesse momento, enquanto a avaliação era distribuída para o restante da turma, de forma individual, voltamos à explicação 
ao modelo de Rutherford, o que permitiu uma melhor compreensão do modelo de RutherfordBohr. Percebemos então o quão é importante a continuidade da proposta e a participação integral do aluno para o alcance dos objetivos propostos.

Antes mesmo dos alunos começarem a responder as avaliações fomos surpreendidos com uma festa preparada por eles para comemorar meu aniversário que se aproximava, todos ficamos entretidos com a comemoração, que foi também uma despedida da equipe de pesquisa, e não houve tempo para que as avalições fossem respondidas. Então combinamos que as avaliações deveriam ser preenchidas em casa. Pedi aos alunos que não utilizassem fontes de pesquisa que não os textos distribuídos por nós, e o próprio professor da turma se encarregou de recolhê-las e nos entregar. Porém, dos 27 alunos presentes na aula apenas 17 devolveram o questionário gerando um total de 17 avaliações respondidas e analisadas. Quanto aos resultados da AA6, temos:

A questão 1 perguntava " $O$ que o modelo de Rutherford-Bohr acrescentou ao modelo atômico de Rutherford?”. As respostas dissertativas foram classificadas em quatro categorias, conforme mostra a tabela a seguir:

Tabela 18: Respostas da questão 1 da Avaliação da Aprendizagem 6.

\section{O que o modelo de Rutherford-Bohr acrescentou ao modelo atômico de Rutherford?}

\begin{tabular}{|l|l|l|}
\hline A & $\begin{array}{l}\text { Os elétrons estariam distribuídos em níveis de energia e nesses níveis se } \\
\text { movimentariam sem perda energética }\end{array}$ & 10 \\
\hline B & $\begin{array}{l}\text { O átomo possui sete níveis de energia e ao ganhar ou perder energia os elétrons } \\
\text { mudam de um nível para o outro }\end{array}$ & 01 \\
\hline C & Os elétrons estão distribuídos em níveis de energia & 04 \\
\hline D & Outras & 02 \\
\hline
\end{tabular}

Como podemos ver, 10 alunos responderam que no modelo de Rutherford-Bohr os elétrons estariam distribuídos em níveis de energia e nesses níveis se movimentariam sem perda energética, 01 resposta indicou que nesse modelo o átomo possui sete níveis de energia e ao ganhar ou perder energia os elétrons mudam de um nível para o outro, 04 alunos responderam apenas que os elétrons estão distribuídos em níveis de energia e 02 respostas não classificaram em nenhuma das categorias anteriores. Para essa questão foi atribuída apenas uma categoria por resposta.

Percebe-se que todas as respostas fazem referência aos níveis de energia. As letras A e B ressaltam ainda o comportamento dos elétrons em virtude da variação energética, mas todas 
as respostas, com exceção da letra D (Outras), que representa uma minoria, são aceitáveis e estão adequadas ao que se pede.

A questão 2 perguntava "Por que, ao longo do tempo, os cientistas propuseram diferentes modelos para representar o átomo?". As respostas dissertativas foram classificadas em seis categorias, conforme mostra a tabela 19:

Tabela 19: Respostas da questão 2 da Avaliação da Aprendizagem 6.

\begin{tabular}{|l|l|l|}
\hline $\begin{array}{l}\text { Por que, ao longo do tempo, os cientistas propuseram diferentes modelos para } \\
\text { representar o átomo? }\end{array}$ & 09 \\
\hline A & Porque surgiram novas descobertas que levaram à modificação dos modelos & 03 \\
\hline B & Porque os modelos foram aperfeiçoados até chegar ao último modelo & 01 \\
\hline C & Porque os modelos não são definitivos & 02 \\
\hline D & Para melhor responder a pergunta "Do que as coisas são feitas?" & 01 \\
\hline E & O modelo atômico ainda pode mudar porque o átomo nunca foi visto & 01 \\
\hline F & Ao longo do tempo eles tentaram definir como é o átomo & \\
\hline
\end{tabular}

Como podemos ver, 09 alunos justificaram a existência de diferentes modelos atômicos devido ao surgimento de novas descobertas que levaram à modificação dos modelos, 03 justificaram dizendo que os modelos foram aperfeiçoados até chegar ao último, 01 aluno respondeu que os diferentes modelos foram propostos porque os modelos não são definitivos, 02 responderam que foram propostos para melhor responder a pergunta "Do que as coisas são feitas?", 01 respondeu que o modelo atômico ainda pode mudar porque o átomo nunca foi visto e 01 que ao longo do tempo eles tentaram definir como é o átomo. Para essa questão foi atribuída apenas uma categoria por resposta.

Ao longo de toda a aplicação do módulo questões referentes à modificação ou substituição dos modelos foram discutidas. É possível perceber que todos os alunos responderam adequadamente a questão. Razões para que os diferentes modelos fossem propostos estão expressas em cada categoria, apesar de diferentes, todas as respostas foram consideradas aceitas dentro do contexto em que foram analisadas. Chamamos atenção apenas para a categoria B, em que alguns alunos utilizam a expressão "último modelo". Verificaremos se tal expressão foi despercebida ou se há uma interpretação de que o último modelo é definitivo analisando a próxima questão. 
A questão 3 perguntava "Esse último modelo atômico é definitivo? Justifique.". As respostas foram classificas em categorias, conforme mostram as tabelas a seguir:

Tabela 20: Respostas da questão 3 (parte a) da Avaliação da Aprendizagem 6.

\begin{tabular}{|l|l|l|}
\hline \multicolumn{2}{|c|}{ Esse último modelo atômico é definitivo? } \\
\hline A & Sim & 02 \\
\hline B & Não & 13 \\
\hline C & Por enquanto sim & 02 \\
\hline
\end{tabular}

Tabela 21: Respostas da questão 3 (parte b) da Avaliação da Aprendizagem 6.

\begin{tabular}{|l|l|c|}
\hline \multicolumn{2}{|l|}{ Justifique. } \\
\hline D & Novas descobertas podem fazer o modelo ser alterado & 09 \\
\hline E & Por se tratar de um modelo, pode ser alterado & 01 \\
\hline F & Esse último modelo pode sofrer alterações & 03 \\
\hline G & No futuro podem surgir novos modelos & 02 \\
\hline H & Acredito que não vão ter outros modelos & 01 \\
\hline I & Não justificou & 01 \\
\hline
\end{tabular}

Como nos mostra a tabela 20, ao perguntar se o último modelo atômico apresentado é definitivo, 02 alunos responderam que sim, 13 alunos responderam que não e 02 alunos responderam que por enquanto sim. Foi pedido ainda que os alunos justificassem suas respostas, tais justificativas encontram-se na tabela 21. Para essa questão foi atribuída apenas uma categoria por resposta.

As categorias D, E e F representam as justificativas dos alunos que responderam não a essa questão e a categoria $\mathrm{G}$ representa a justificativa daqueles que responderam que por enquanto sim. Se tratando da letra G, podemos perceber que a justificativa dada pelos alunos, de que atualmente esse modelo é definitivo, mas que no futuro podem surgir novos modelos e aqueles que eram podem não ser mais definitivos, faz com que essas respostas sejam tão aceitas quanto à dos alunos que responderam não. Esses que responderam não enfatizaram a possibilidade de alteração do último modelo apresentado. Em ambos os casos as respostas foram consideradas aceitas dentro do contexto em que foram analisadas. Já as letras H e I representam as justificativas daqueles que responderam sim. Desses, um não justificou e o outro respondeu que acredita que não vão ter outros modelos. São respostas não aceitas cientificamente. 
Fazendo uma comparação com a questão 2 (parte a) da AA1 que perguntava "Os modelos científicos atualmente aceitos pela comunidade científica são definitivos?" é possível perceber uma mudança de opinião. Nessa questão todos os alunos, sem exceção, responderam não, concordando que os modelos científicos não são definitivos. Já na atual questão, que trata especificamente do modelo atômico, dois alunos responderam sim, concordando que o último modelo é definitivo.

Ainda que a resposta para a atual questão não tenha sido unanime, o número de alunos que considera o último modelo definitivo representa uma minoria. Podemos perceber com base nesses resultados que a abordagem dada aos conteúdos ao longo da aplicação da proposta superou a abordagem estritamente tradicional criticada por diversos autores ao longo deste trabalho. Justi (2011), por exemplo, constatou em um estudo sobre modelos e modelagem no ensino de Química que a maioria dos estudantes pensa que o modelo mais recente é perfeito e declara que esse fato se deve a uma abordagem não adequada e não esclarecida a respeito dos modelos. Aqui os resultados apontaram que esses são a minoria. A maioria, além de não concordar que o último modelo é definitivo, consegue expor diferentes justificativas para essa questão. Não atribuímos esse fato há um método ou momento exclusivos, mas ao conjunto de recursos e estratégias utilizadas durante a abordagem de toda a proposta.

A questão 4 perguntava "Quais são as principais características do modelo atômico de Dalton, Thomson, Rutherford e Rutherford-Bohr? Descreva e ilustre: a) Dalton; b) Thomson; c) Rutherford; d) Rutherford-Bohr.”. As respostas referentes a cada letra foram classificadas em categorias para facilitar as análises, como mostram as tabelas a seguir:

\section{a) Dalton}

Tabela 22: Respostas da questão 4a (parte a) da Avaliação da Aprendizagem 6.

Quais são as principais características do modelo atômico de Dalton? Descreva e ilustre:

\begin{tabular}{|l|l|l|}
\hline A & Pequeno, esférico, maciço, indivisível e indestrutível & 07 \\
\hline B & Esférico, maciço, indivisível e indestrutível & 06 \\
\hline $\mathbf{C}$ & Maciço, indivisível e indestrutível & 01 \\
\hline $\mathbf{D}$ & Partícula indivisível e indestrutível & 02 \\
\hline $\mathbf{E}$ & Esfera maciça & 01 \\
\hline
\end{tabular}


Tabela 23: Respostas da questão 4a (parte b) da Avaliação da Aprendizagem 6.

\begin{tabular}{|l|l|l|}
\hline \multicolumn{2}{|c|}{ Quais são as principais características do modelo atômico de Dalton? Descreva e ilustre: } \\
\hline F & Desenho de uma esfera lisa & 15 \\
\hline G & Não desenhou & 02 \\
\hline
\end{tabular}

Conforme podemos ver na tabela 22, 07 respostas descrevem o modelo atômico de Dalton como pequeno, esférico, maciço, indivisível e indestrutível, 06 o descrevem como esférico, maciço, indivisível e indestrutível, 01 o descreve como maciço, indivisível e indestrutível, 02 o descrevem como uma partícula indivisível e indestrutível e 01 o descreve como uma esfera maciça. Para essa questão foi atribuída apenas uma categoria por resposta.

Nota-se que todas as respostas, algumas mais completas e outras menos, expressam características do modelo atômico de Dalton, sendo assim consideradas aceitas.

Já as ilustrações representadas na tabela 23 mostram que 15 alunos representou o modelo atômico de Dalton por meio do desenho de uma esfera, representação essa muito comum e considerada aceita, e 02 alunos não fizeram a ilustração. Algumas dessas ilustrações podem ser observadas nas figuras 34 e 35 .
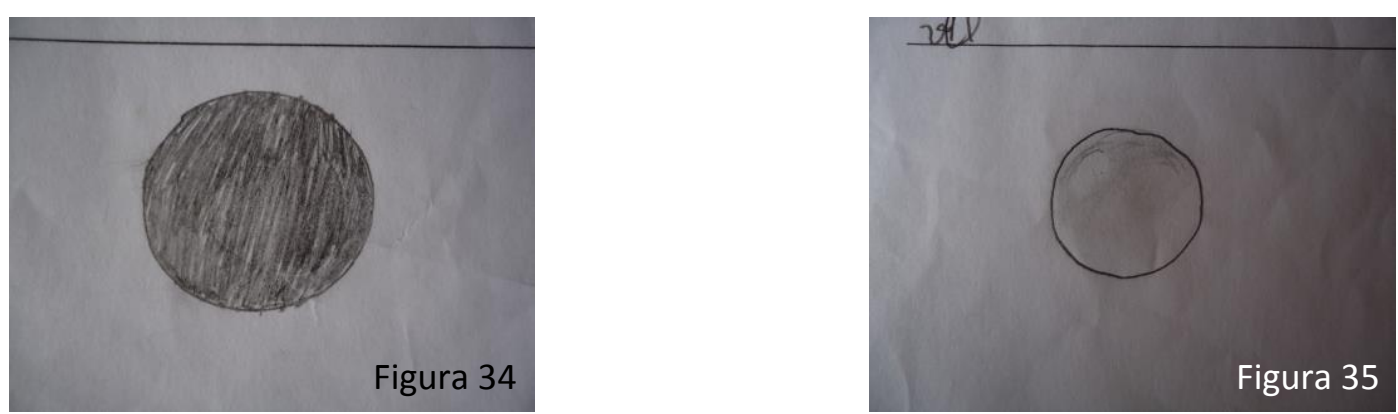

Figuras 34 e 35: Desenho representado pela categoria F da tabela 23.

\section{b) Thomson}

Tabela 24: Respostas da questão 4b (parte a) da Avaliação da Aprendizagem 6.

\begin{tabular}{|l|l|l|}
\hline \multicolumn{2}{|l|}{$\begin{array}{l}\text { Quais são as principais características do modelo atômico de Thomson? Descreva e } \\
\text { ilustre: }\end{array}$} \\
\hline A & Uma esfera carregada positivamente com partículas negativas incrustadas & 08 \\
\hline B & Uma esfera divisível incrustada de elétrons & 05 \\
\hline C & Uma esfera divisível que possui cargas positivas e negativas & 02 \\
\hline D & Possui elétrons & 02 \\
\hline
\end{tabular}


Tabela 25: Respostas da questão 4b (parte b) da Avaliação da Aprendizagem 6.

\begin{tabular}{|l|l|l|}
\hline \multicolumn{2}{|l|}{ Quais são as principais características do modelo atômico de Thomson? Descreva e } \\
ilustre: \\
\hline E & Desenho de uma esfera com vários pontos & 12 \\
\hline F & Desenho de uma esfera com vários pontos identificados com sinais de negativo (-) & 02 \\
\hline G & $\begin{array}{l}\text { Desenho de uma esfera identificada com sinais de positivo (+) e vários pontos } \\
\text { identificados com sinais de negativo (-) }\end{array}$ & 01 \\
\hline H & Não desenhou & 02 \\
\hline
\end{tabular}

Conforme mostra a tabela 24, 08 alunos descreveram o modelo atômico de Thomson como uma esfera carregada positivamente com partículas negativas incrustadas, 05 alunos o descreveram como uma esfera divisível incrustada de elétrons, 02 alunos o descreveram como uma esfera divisível que possui cargas positivas e negativas e 02 disseram que esse modelo atômico possui elétrons. Para essa questão foi atribuída apenas uma categoria por resposta.

As respostas, apesar de diferentes, foram consideradas aceitas. A letra A representa claramente a descrição mais usual do modelo atômico de Thomson. As letras B e C ressaltaram a característica divisível desse modelo, sendo que a letra $\mathrm{C}$, apesar de não especificar em qual parte da estrutura se encontram, indicou a existência cargas positivas e negativas. A letra D representa as respostas que indicaram apenas que esse modelo atômico possui elétrons, característica evidente quando se compara esse modelo com o modelo atômico de Dalton.

Já com relação às ilustrações, 12 alunos fizeram o desenho de uma esfera com vários pontos, 02 alunos fizeram o desenho de uma esfera com vários pontos identificados com sinais de negativo, 01 alunos fez o desenho de uma esfera identificada com sinais de positivo e vários pontos identificados com sinais de negativo e 02 alunos não fizeram a ilustração. Apesar dos desenhos representados pela letra E não identificarem os pontos na esfera deduzse que se trata dos elétrons. Os desenhos se diferenciam apenas por identificarem ou não as cargas com sinais de positivo ou negativo, sendo assim considerados todos aceitos dentro do contexto em que foram analisados. Algumas dessas ilustrações podem ser observadas nas figuras 36,37 e 38 . 

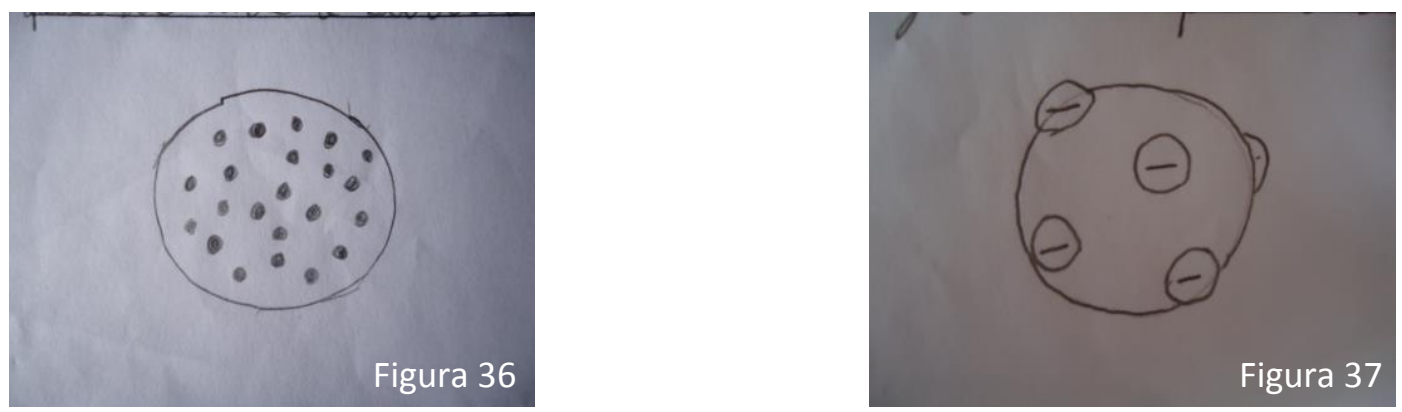

Figura 36: Desenho representado pela categoria E da tabela 25.

Figura 37: Desenho representado pela categoria F da tabela 25.

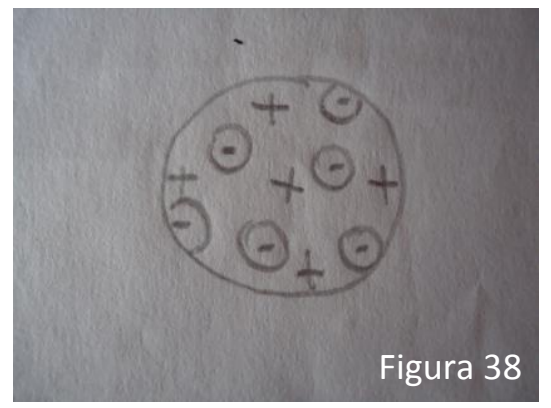

Figura 38: Desenho representado pela categoria G da tabela 25.

\section{c) Rutherford}

Tabela 26: Respostas da questão 4c (parte a) da Avaliação da Aprendizagem 6.

\begin{tabular}{|l|l|l|}
\hline \multicolumn{2}{|l|}{$\begin{array}{l}\text { Quais são as principais características do modelo atômico de Rutherford? Descreva e } \\
\text { ilustre: }\end{array}$} \\
\hline A & $\begin{array}{l}\text { Possui um núcleo com partículas positivas e elétrons girando em orbitais ao redor do } \\
\text { núcleo numa região chamada de eletrosfera }\end{array}$ & 03 \\
\hline B & Possui um núcleo com partículas positivas e uma região chamada de eletrosfera & 01 \\
\hline C & $\begin{array}{l}\text { Possui um pequeno núcleo com prótons e elétrons se movimentando de forma } \\
\text { desorganizada }\end{array}$ & 01 \\
\hline D & Possui um núcleo, elétrons girando em orbitais ao redor do núcleo e espaços vazios & 01 \\
\hline E & Possui núcleo, elétrons e eletrosfera & 04 \\
\hline F & Possui elétrons circulando desordenadamente e espaços vazios & 02 \\
\hline G & Esse modelo não explicava devidamente o movimento dos elétrons & 01 \\
\hline H & Outras & 04 \\
\hline
\end{tabular}


Tabela 27: Respostas da questão 4c (parte b) da Avaliação da Aprendizagem 6.

\begin{tabular}{|c|l|c|}
\hline \multicolumn{2}{|l|}{$\begin{array}{l}\text { Quais são as principais características do modelo atômico de Rutherford? Descreva e } \\
\text { ilustre: }\end{array}$} & 06 \\
\hline I & Desenhou o núcleo com elétrons ao redor & 02 \\
\hline J & Desenhou o núcleo com orbitais ao redor & 05 \\
\hline K & Desenhou prótons no núcleo e elétrons ao redor do núcleo & 03 \\
\hline L & $\begin{array}{l}\text { Desenhou o núcleo, uma região vazia ao redor do núcleo e elétrons ao redor dessa } \\
\text { região vazia }\end{array}$ & 01 \\
\hline M & Não desenhou & \\
\hline
\end{tabular}

Conforme podemos ver na tabela 26, 03 alunos descreveram o modelo atômico de Rutherford dizendo que ele possui um núcleo com partículas positivas e elétrons girando em orbitais ao redor do núcleo numa região chamada de eletrosfera, 01 aluno o descreveu dizendo que ele possui um núcleo com partículas positivas e uma região chamada de eletrosfera, 01 o descreveu dizendo que ele possui um pequeno núcleo com prótons e elétrons se movimentando de forma desorganizada, 01 disse que ele possui um núcleo, elétrons girando em orbitais ao redor do núcleo e espaços vazios, 04 disseram que ele possui núcleo, elétrons e eletrosfera, 02 que possui elétrons circulando desordenadamente e espaços vazios, 01 o descreveu dizendo que esse modelo não explicava devidamente o movimento dos elétrons e 04 respostas não classificaram em nenhuma das categorias acima. Para essa questão foi atribuída apenas uma categoria por resposta.

As categorias apresentadas na tabela descrevem aspectos do modelo atômico de Rutherford cientificamente aceitos, com exceção apenas da letra H (Outras) em que, das quatro respostas, três descrevem as partículas alfa e das letras $\mathrm{C}$ e $\mathrm{F}$ que em partes descrevem que os elétrons se movimentam de forma desorganizada e desordenada.

Já com relação às ilustrações, apesar dos alunos não terem identificado as estruturas é possível deduzir o que seria o núcleo, os elétrons, a eletrosfera e as demais partes. Dentre os 16 alunos que fizeram a ilustração, 06 desenharam o núcleo com elétrons ao redor, 02 desenharam o núcleo com orbitais ao redor, 05 desenharam prótons no núcleo e elétrons ao redor do núcleo e 03 desenharam o núcleo, uma região vazia ao redor do núcleo e elétrons ao redor dessa região vazia. Apenas nessa última categoria (letra L) percebe-se um equívoco na estrutura do átomo segundo Rutherford. Nesse modelo atômico a região menos densa que contém espaços vazios é a mesma região que se encontram os elétrons, porém no desenho está representada uma região vazia e uma região mais externa onde estão os elétrons. Algumas dessas ilustrações podem ser observadas nas figuras abaixo. 

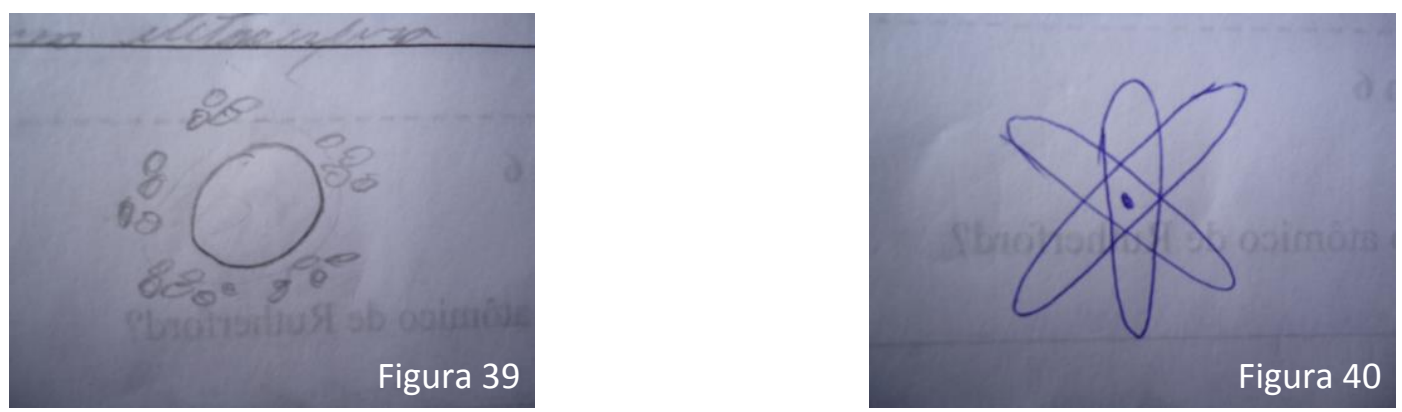

Figura 39: Desenho representado pela categoria I da tabela 27.

Figura 40: Desenho representado pela categoria J da tabela 27.
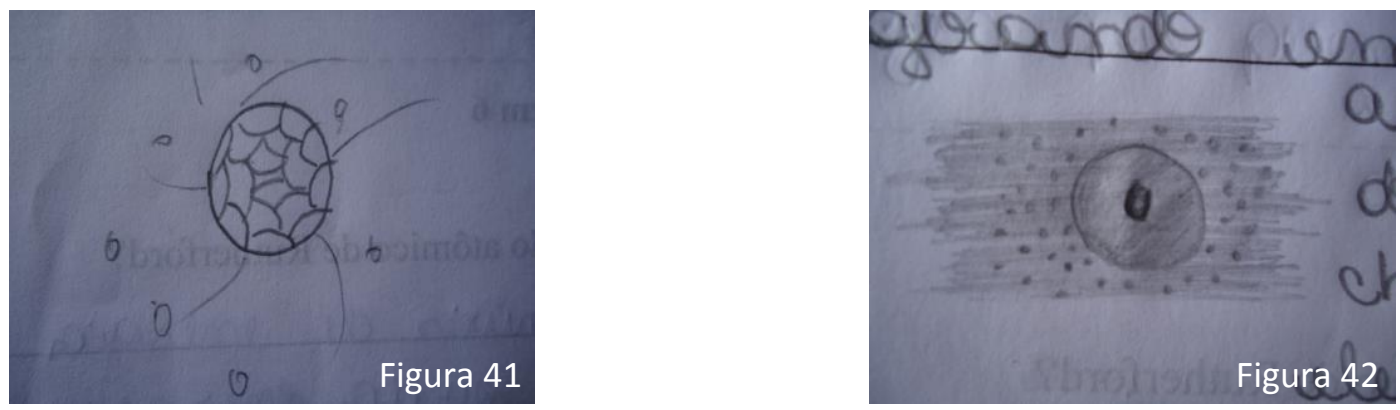

Figura 41: Desenho representado pela categoria K da tabela 27.

Figura 42: Desenho representado pela categoria L da tabela 27.

\section{d) Rutherford-Bohr}

Tabela 28: Respostas da questão 4d (parte a) da Avaliação da Aprendizagem 6.

Quais são as principais características do modelo atômico de Rutherford-Bohr? Descreva e ilustre:

\begin{tabular}{|l|l|l|}
\hline A & $\begin{array}{l}\text { Os elétrons estão distribuídos em níveis de energia e nesses níveis se movimentam } \\
\text { sem perder energia }\end{array}$ & 04 \\
\hline B & $\begin{array}{l}\text { É o modelo de Rutherford aperfeiçoado, nele os elétrons estão distribuídos em níveis } \\
\text { de energia e nesses níveis se movimentam sem perder energia }\end{array}$ & 01 \\
\hline C & Ao ganhar ou perder energia os elétrons mudam de um nível para o outro & 02 \\
\hline D & O átomo possui sete níveis de energia & 03 \\
\hline E & Os elétrons estão distribuídos em níveis de energia & 03 \\
\hline F & Os elétrons estão distribuídos em níveis de energia e o átomo possui nêutrons & 02 \\
\hline G & Os elétrons circulam em órbita & 01 \\
\hline H & Não respondeu & 01 \\
\hline
\end{tabular}


Tabela 29: Respostas da questão 4d (parte b) da Avaliação da Aprendizagem 6.

\begin{tabular}{|l|l|l|}
\hline $\begin{array}{l}\text { Quais são as principais características do modelo atômico de Rutherford-Bohr? } \\
\text { Descreva e ilustre: }\end{array}$ \\
\hline $\mathbf{I}$ & Desenhou o núcleo e elétrons organizados em níveis de energia & 07 \\
\hline $\mathbf{J}$ & $\begin{array}{l}\text { Desenhou o núcleo e elétrons organizados em níveis de energia representados em } \\
\text { diferentes dimensões }\end{array}$ & 07 \\
\hline K & Desenhou o núcleo com elétrons ao redor & 01 \\
\hline L & Não desenhou & 02 \\
\hline
\end{tabular}

Como podemos ver na tabela 28, ao descreverem o modelo atômico de RutherfordBohr 04 alunos disseram que os elétrons estão distribuídos em níveis de energia e nesses níveis se movimentam sem perder energia, 01 aluno disse que o modelo de Rutherford-Bohr é o modelo de Rutherford aperfeiçoado, nele os elétrons estão distribuídos em níveis de energia e nesses níveis se movimentam sem perder energia, 02 alunos disseram que ao ganhar ou perder energia os elétrons mudam de um nível para o outro, 03 alunos responderam a essa questão dizendo que segundo esse modelo o átomo possui sete níveis de energia, 03 responderam dizendo que os elétrons estão distribuídos em níveis de energia, 02 que os elétrons estão distribuídos em níveis de energia e o átomo possui nêutrons, 01 que os elétrons circulam em órbita e 01 não respondeu a questão. Para essa questão foi atribuída apenas uma categoria por resposta.

Todas as respostas dadas a essa questão representam características do modelo atômico de Rutherford-Bohr. Vale ressaltar ainda que os critérios representados pelas letras A e B se diferenciam apenas na parte em que o critério B explicita que esse modelo é na realidade o modelo de Rutherford aperfeiçoado. De modo semelhante os critérios E e F se diferem apenas na parte em que o critério $\mathrm{F}$ acrescenta a presença dos nêutrons nesse modelo.

Já com relação às ilustrações, 07 alunos desenharam o núcleo e elétrons organizados em níveis de energia, 07 alunos desenharam o núcleo e elétrons organizados em níveis de energia representados em diferentes dimensões, 01 aluno desenhou o núcleo com elétrons ao redor e 02 alunos não fizeram a ilustração. As ilustrações das categorias I e J representam de forma aceitável o modelo atômico de Rutherford-Bohr. Já o aluno que fez a ilustração representada pela categoria $\mathrm{K}$ criou dois desenhos iguais para representar tanto o modelo atômico de Rutherford quanto o modelo atômico de Rutherford-Bohr. Alguns desses desenhos podem ser observados nas figuras 43,44 e 45. 

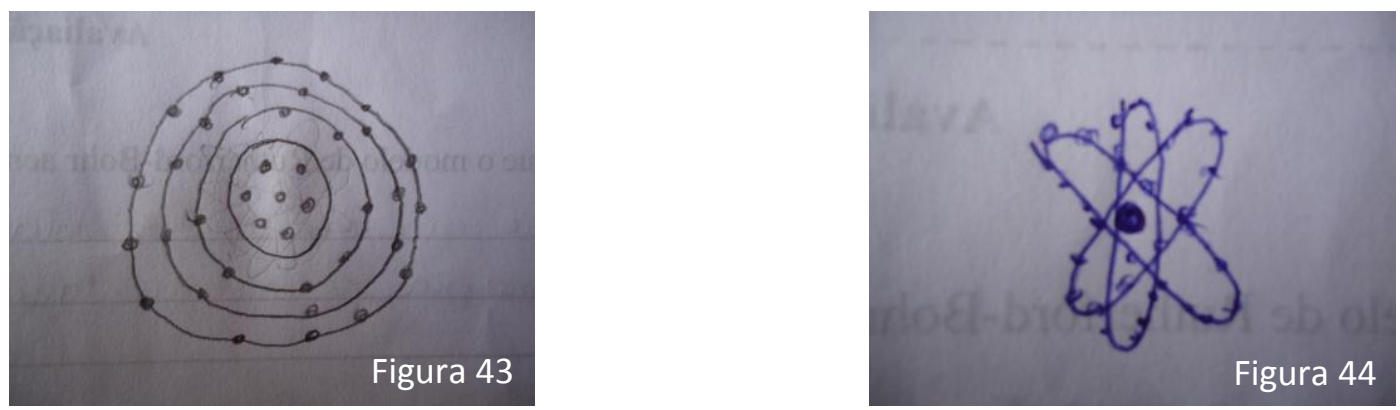

Figura 43: Desenho representado pela categoria I da tabela 29.

Figura 44: Desenho representado pela categoria J da tabela 29.

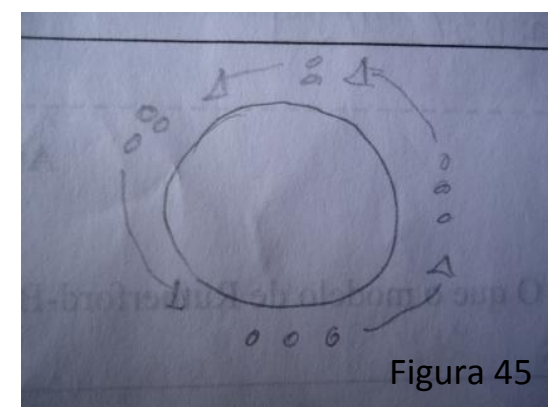

Figura 45: Desenho representado pela categoria K da tabela 29.

A questão 5 perguntava "Muitas pessoas acreditavam que a ciência era sempre correta e absoluta. E você, como caracteriza o conhecimento científico?". As respostas dissertativas foram classificadas em cinco categorias, conforme mostra a tabela 30 :

Tabela 30: Respostas da questão 5 da Avaliação da Aprendizagem 6.

\begin{tabular}{|l|l|l|}
\hline \multicolumn{2}{|l|}{$\begin{array}{l}\text { Muitas pessoas acreditavam que a ciência era sempre correta e absoluta. E você, como } \\
\text { caracteriza o conhecimento científico? }\end{array}$} \\
\hline A & $\begin{array}{l}\text { O conhecimento científico não é correto e absoluto, novas informações podem surgir } \\
\text { e modificar o que antes era aceito }\end{array}$ & 09 \\
\hline B & A ciência é correta até que se prove o contrário & 02 \\
\hline C & O conhecimento científico é relativo & 01 \\
\hline D & O conhecimento científico está em constante mudança & 02 \\
\hline E & Outras & 03 \\
\hline
\end{tabular}

Como podemos ver na tabela acima, 09 alunos caracterizam o conhecimento científico dizendo que ele não é correto e nem absoluto, novas informações podem surgir e modificar o que antes era aceito, 02 responderam que a ciência é correta até que se prove o contrário, 01 respondeu que o conhecimento científico é relativo, 02 que o conhecimento científico está em constante mudança e 03 respostas não classificaram em nenhuma das categorias acima. Para essa questão foi atribuída apenas uma categoria por resposta. 
Todas as categorias acima representadas, com exceção da letra E (Outras), são consideradas aceitas dentro do contexto em que foram analisadas. Todas elas se referem ao conhecimento científico com a possibilidade de alteração. As respostas classificadas no critério E expressam características da ciência que não se referem ao aspecto pedido.

Fazendo-se uma análise geral dos resultados, podemos deduzir que os objetivos propostos foram alcançados. As respostas em sua grande maioria foram consideradas cientificamente aceitas. Quanto à abordagem dos conteúdos é possível perceber claramente a contribuição dos métodos e recursos utilizados. Vale ressaltar que com o decorrer das aulas falhas na abordagem e novas ideias surgiram levando ao acréscimo ou modificação da proposta. Ressaltamos ainda que tais alterações levam ao aprimoramento da proposição e são recomentados a cada abordagem visando o alcance dos objetivos propostos e a aprendizagem consistente dos conceitos científicos. Tendo finalizado a verificação e análise dos resultados, passaremos as considerações acerca do trabalho e de suas contribuições para o ensino. 


\section{CONSIDERAÇÕES FINAIS}

Consideramos que o ensino de modelos atômicos no $9^{\circ}$ ano do Ensino Fundamental tem sido conduzido de forma a não alcançar os objetivos propostos, já que muitos alunos chegam ao Ensino Médio sem ter compreensão sobre o significado de modelos atômicos. Aspectos como a não valorização da construção histórica dos modelos, o fato de o átomo ser uma realidade impossível de ser vista, a não contextualização do conteúdo nos livros didáticos, as distorções conceituais presentes ainda nesses livros, a fragmentação dos conteúdos, o preparo acadêmico insuficiente de professores que não lhes têm permitido uma atuação adequada na abordagem desse tema, a forma acabada e imutável como o mesmo é apresentado e o uso desordenado de analogias, metáforas, imagens e modelos têm influenciado negativamente nesse processo. Tendo essa problemática em vista não é difícil perceber a extrema necessidade de inserção de metodologias diferenciadas que abranjam a utilização de recursos tecnológicos, realização de atividades experimentais, construção de modelos, dentre outros recursos que colaborem com um ensino de Ciências que envolva o aluno como agente ativo no processo de aquisição do conhecimento possibilitando a aprendizagem consistente dos conceitos científicos numa perspectiva de formação crítica cidadã.

Levando em consideração a importância que tem sido dada ao livro didático no processo de ensino-aprendizagem dos conteúdos científicos em toda a Educação básica, tornase importante que os cursos de formação inicial de professores abordem aspectos relacionados ao processo de seleção dos livros com o objetivo de possibilitar que o professor tenha uma visão mais crítica ao selecionar um livro didático. É importante também que tal abordagem abranja a finalidade da utilização do livro em sala para que o mesmo venham ser utilizado como recurso auxiliador que é e em hipótese alguma como ferramenta exclusiva detentora de verdades absolutas, como tem sido constatado (ECHEVERRÍA, MELLO e GAUCHE, 2011).

Quanto à verificação da abordagem dos conceitos de átomo nos livros didáticos de Ciências do $9^{\circ}$ ano do Ensino Fundamental aprovados pelo PNLD/2014, concluímos que todos aqueles que abordam os modelos atômicos, o equivalente a 90\%, o fazem de forma não recomendada pelos PCN, com aprofundamentos nos conteúdos relacionados ao átomo. Além dos aprofundamentos, não há muita variação nas estratégias de ensino propostas e essas não se mostram adequadas e/ou colaboradoras para uma aprendizagem significante dos conceitos. 
Percebe-se que os livros didáticos têm utilizado de metodologias tradicionais, que quando utilizadas de forma exclusiva, não são suficientes para promover um ensino de qualidade. Foi possível constatar que menos de um terço dos livros verificados propõe ao menos uma atividade que se caracteriza como atividade experimental de acordo com o conceito adotado nesse trabalho, no qual, segundo Silva, Machado e Tunes (2011) “... pode ser entendida como uma atividade que permita a articulação entre fenômenos e teorias." (p. 235) podendo ser realizada em diferentes espaços.

Nesse contexto, consideramos de extrema relevância que os livros didáticos sejam escolhidos de forma mais criteriosa, pois apesar das contribuições do PNLD ainda são encontrados nesses livros erros conceituais, imagens impróprias e analogias inadequadas que proporcionam a aprendizagem distorcida dos conceitos (MILARÉ e ALVES FILHO, 2010). Defendemos também que os livros sejam utilizados como instrumento de apoio associado a outros recursos e outros meios de informação em razão da sofisticação dos artefatos educacionais disponíveis, visando uma aprendizagem consistente dos conteúdos (ECHEVERRÍA, MELLO e GAUCHE, 2011).

Quanto à proposição, essa foi elaborada tendo por conhecimento as principais dificuldades enfrentadas por professores e alunos no processo de ensino-aprendizagem dos conteúdos relacionados ao átomo tendo por base um direcionamento histórico e experimental, foi implementada e a análise dos resultados mostrou que a abordagem sugerida contribuiu de forma significante para o ensino dos conteúdos propostos.

A inserção de estratégias diferenciadas, como aulas dialógicas, experimentação e construção de modelos, somadas aos textos e demais recursos elaborados foram imprescindíveis para que a aplicação da proposição gerasse os bons resultados constatados. Consideramos que as atividades experimentais, assim como defendem Silva, Machado e Tunes (2011), permitiram a articulação entre os fenômenos e teorias apresentados e auxiliaram na aprendizagem dos conceitos científicos por meio da valorização e da interrelação teoria-prática (SILVA e ZANON, 2000). Ressaltamos a importância dos momentos de discussão e reflexão auxiliados pelo fornecimento de evidências experimentais, pelo uso de linguagem científica e explicação no nível teórico conceitual que foram e só serão possíveis por meio da intervenção do professor (SILVA e ZANON, 2000).

A utilização da modelagem, que Hodson (1994) considera como atividade experimental, também foi imprescindível para o alcance dos objetivos propostos. Os resultados da implementação da proposta apontaram para o que também foi constatado por 
Justi (2011) em um estudo sobre modelos e modelagem no ensino de Química, que a maior parte dos estudantes da turma investigada aprendeu o conteúdo envolvido nas estratégias de ensino de forma significativa, desenvolveu habilidades investigativas e desenvolveu capacidade de visualização do abstrato nos modelos. Mas apesar dos bons resultados obtidos sabe-se que os modelos se utilizados de forma inadequada sempre falham no conceito e objetivos (JUSTI, 2011).

Sendo assim, torna-se crucial o papel do professor frente ao processo de ensinoaprendizagem sendo ele o detentor da autonomia na escolha e utilização dos livros didáticos, na elaboração dos planos de aula e escolha dos recursos a serem utilizados, sendo o responsável por direcionar discussões e reflexões acerca dos conteúdos e experimentos desenvolvidos e por meio de intervenções e proposições intencionais estimular os alunos a exporem suas ideias e se essas não forem adequadas os animarem a modificá-las ou a produzirem outras novas (SILVA e ZANON, 2000).

Consideramos que o módulo didático se mostrou eficaz quanto ao alcance de seus objetivos. As estratégias diferenciadas, diferentes daquelas propostas nos livros didáticos, possibilitaram a aprendizagem dos conceitos relacionados ao átomo. Quanto à abordagem da construção histórica dos conceitos químicos foi possível constatar que essa pode colaborar para que os alunos desmistifiquem o caráter acabado e imutável das descobertas científicas, conforme mostraram os resultados analisados. 


\section{REFERÊNCIAS BIBLIOGRÁFICAS}

ANDRADE, B. L.; ZYLBERSZTAJN, A.; FERRARI, N. Analogias e Metáforas no Ensino de Ciências à Luz da Epistemologia de Gaston Bachelard. Ensaio. Pesquisa em Educação em Ciências, Belo Horizonte, v. 2, n.2, p. 231-245, 2002.

AZEVEDO, R. O. M. et al. Formação inicial de professores da educação básica no Brasil: trajetória e perspectivas. Revista Diálogo Educ., Curitiba, v. 12, n. 37, p. 997-1026, set./dez. 2012.

BACHELARD, G. A formação do espírito científico: contribuição para uma psicanálise do conhecimento. Tradução Esteia dos Santos Abreu. Rio de Janeiro: Contraponto, 316 p., 1996.

BARROS, C.; PAULINO, W. Ciências - $9^{\circ}$ ano. Editora Ática, ed. 5a , São Paulo, 2013.

BEMFEITO, A. P.; PINTO, C. E. Perspectiva Ciências - $9^{\circ}$ ano. Editora do Brasil, ed. 2a, São Paulo, 2012.

BRASIL. Ministério da Educação. Guia de Livros Didáticos PNLD 2014: Ciências, Anos Finais do Ensino Fundamental. Brasília: MEC, 2013.

BRASIL. Ministério da Educação. Parâmetros Curriculares Nacionais: Ciências Naturais. Brasília: MEC, 1998.

BRÖCKELMANN, R. H. (Editora responsável). Observatório de Ciências - $9^{\circ}$ ano. Editora Moderna, ed. 1a, São Paulo 2013.

CANTO, E. L. Ciências Naturais - Aprendendo com o cotidiano - $9^{\circ}$ ano. Editora Moderna, ed. $4^{\text {a }}$, São Paulo, 2012.

CARNEVALLE, M. R. (Editora responsável). Jornadas.cie - $9^{\circ}$ ano. Editora Saraiva, ed. 2a, São Paulo, 2012.

CARVAlhO, W. L. P.; AlVES, J. A. P.; CAETANO, L. Ciências para nosso tempo - $9^{\circ}$ ano.Editora Positivo, ed. 1 ${ }^{\text {a }}$, Curitiba, 2011. 
CHAGAS, A. P. As Ferramentas do Químico. Química Nova na Escola, n. 5, p. 18-20, maio de 1997.

CORREIA, E. S. Por que Ensinar Ciências na Escola Fundamental? Meu Artigo, 2011. Disponível em: <http://meuartigo.brasilescola.com/educacao/por-que-ensinar-ciencias-naescola-fundamental.htm>. Acesso em: 15 nov. 2013.

DISTRITO FEDERAL. Secretaria de Educação do Distrito Federal. Currículo da Educação Básica, Séries Finais do Ensino Fundamental. Brasília: SEDF, 2000.

DISTRITO FEDERAL. Secretaria de Educação do Distrito Federal. Currículo da Educação Básica, Anos Finais do Ensino Fundamental. Brasília: SEDF, 2010.

ECHEVERRÍA, A. R.; MELLO, I. C.; GAUCHE, R. Livro Didático: Análise e Utilização no Ensino de Química. Em: SANTOS, W. L. P.; MALDANER, O. A. (Org). Ensino de Química em Foco. Rio Grande do Sul: Unijuí, 2011.

FAVAlli, L. D.; Silva, K. A. P.; ANGElO, E. A. Projeto Radix - Ciências- $9^{\circ}$ ano. Editora Scipione, ed. 2a , São Paulo, 2013.

FERNANDES, J. F. et al. Educação Ambiental e Construção de Modelos no Ensino de Jovens e Adultos: Resinificando o Ensino de Química com Oficinas Pedagógicas. Em: XVI Encontro Nacional de Ensino de Química. Atas do XVI ENEQ. Salvador, BA, 2012.

FERREIRA, P. F. M. Modelagem e suas Contribuições para o Ensino de Ciências: Uma Análise no Estudo de Equilíbrio Químico. Belo Horizonte, 2006. Dissertação (Mestrado em Educação), Programa de Pós-Graduação da Faculdade de Educação, Universidade Federal de Minas Gerais, MG, 2006.

FERREIRA, P. F. M.; JUSTI, R. S. Modelagem e o "Fazer Ciência". Química Nova na Escola, n. 28, p. 32-36, maio de 2008.

FOUREZ, G. Crise no Ensino de ciências? Investigações em Ensino de Ciências, vol. 8(2), p. 109-123, 2003.

FRANCISCO JUNIOR, W. E. Analogias em Livros Didáticos de Química: um Estudo das Obras Aprovadas pelo Plano Nacional do Livro Didático para o Ensino Médio 2007. Ciência e Cognição, vol. 14, p. 121-143, 2009. 
FRANÇA, A. C. G.; MARCONDES, M. E. R.; do CARMO, M. P. Estrutura Atômica e Formação dos Íons: Uma Análise das Ideias dos Alunos do $3^{\circ}$ Ano do Ensino Médio. Química Nova na Escola, v. 31, p. 275-282, 2009.

FUMAGALLI, L. O Ensino de Ciências Naturais no Nível Fundamental de Educação Formal: Argumentos a seu Favor. Em: WEISSMANN, H. (Org.). Didática das Ciências Naturais: contribuições e reflexões. Porto Alegre: ArtMed, 1998.

GEWANDSZNAJDER, F. Projeto Teláris: Ciências $-9^{\circ}$ ano. Editora Ática, ed. $1^{\mathrm{a}}$, São Paulo, 2012.

GIOPPO, C.; SCHEFFER, E. W. O.; NEVES, M. C. D. O ensino experimental na escola fundamental: uma reflexão de caso no Paraná. Educar, n. 14, p. 39-57, 1998.

GIORDAN, M. O Papel da Experimentação no Ensino de Ciências. Química Nova na Escola, n. 10, p. 43-49, novembro de 1999.

GODOY, L. P.; OGO, M. Y. Vontade de saber ciências- $9^{\circ}$ ano. Editora FDT, ed. $1^{\text {a }}$, São Paulo, 2012.

GOMES, H. J. P.; OLIVEIRA, O. B. Obstáculos Epistemológicos no Ensino de Ciências: Um Estudo sobre suas Influências nas Concepções de Átomo. Ciências \& Cognição, v. 12, p. 113, 2007.

GOWDAK, D. O.; MARTINS, E. L. Ciências novo pensar - Edição renovada- $9^{\circ}$ ano. Editora FTD, ed. 1ª, São Paulo, 2012.

GRECA, I. M. Algumas metodologias para o estudo de modelos mentais. Em: SANTOS, F. M. T.; GRECA, I. M. (Org). A Pesquisa em Ensino de Ciências no Brasil e suas metodologias. Rio Grande do Sul: Unijuí, p. 391-428, 2011.

HODSON, D. Hacia un enfoque más crítico del trabajo de laboratorio. Enseñanza de las ciencias, v. 12(3), p. 299-313, 1994.

JUSTI, R. Modelos e Modelagem no Ensino de Química: Um olhar sobre aspectos essenciais pouco discutidos. Em: SANTOS, W. L. P.; MALDANER, O. A. (Org). Ensino de Química em Foco. Rio Grande do Sul: Unijuí, 2011.

KRASILCHIK, M. Prática de Ensino de Biologia. São Paulo, EdUSP, ed. 4a , 2004. 
LEITE, V. M.; SILVEIRA, H. E.; DIAS, S. S. Obstáculos Epistemológicos em Livros Didáticos: Um Estudo das Imagens de Átomos. Revista Virtual Candombá, v. 3, p. 1-8, 2006.

LIMA, M. C. R.; ROTTA, J. C. G.; RAZUCK, R. C. R. S. Concepções dos Estudantes que Ingressam no Ensino Médio sobre Ligações Químicas. Em: VIII Encontro Nacional de Pesquisa em Educação em Ciências. Atas do VIII ENPEC.Campinas, SP, 2011.

MALAFAIA, G.; RODRIGUES, A. S. L. Uma Reflexão sobre o Ensino de Ciências no Nível Fundamental da Educação. Ciência e Ensino, vol. 2, n. 2, junho de 2008.

MARQUES, D. M.; CALUZI, J. J. Ensino de Química e História da Ciência: O Modelo Atômico de Rutherford. Em: IV Encontro Nacional de Pesquisa em Educação em Ciências. ATAS do IV ENPEC. Bauru, 2003.

MARTINS, I. P. et al. Programa de Química. Portugal: MEC, 2004.

MILARÉ, T. Ciências na $8^{a}$ Série: da Química Disciplinar à Química do Cidadão.Florianópolis, SC, 2008.Dissertação (Mestrado em Educação Científica e Tecnológica), Programa de Pós-Graduação, Universidade Federal de Santa Catarina, SC, 2008.

MILARÉ, T.; ALVES FILHO, J. P. A Química Disciplinar em Ciências do $9^{\circ}$ Ano. Química nova na escola, vol. 32, n. 1, p. 43-52, 2010.

MOISÉS, H. N. Ciências da Natureza - $9^{\circ}$ ano. Editora IBEP, ed. $3^{\text {a }}$, São Paulo, 2012.

MORETTI, R. Ciências nos dias de hoje - $9^{\circ}$ ano. Editora Leya, São Paulo, 2012.

MORTIMER, E. F. Concepções Atomistas dos Estudantes. Química Nova na Escola, v. 1, n.1, p. 23-26, 1995.

NERY, A. L. P.; KILLNER, G. I. Para viver juntos - Ciências $-9^{\circ}$ ano. Editora SM, ed. $3^{\mathrm{a}}$, São Paulo, 2012.

PEDUZZI, L. O. Q.; BASSO, A. C. Para o Ensino do Átomo de Bohr no Nível Médio. Revista Brasileira de Ensino de Física, São Paulo, v. 27, n.4, p. 545-557, 2005. 
POZO, J. I.; CRESPO, M. A. G. A Aprendizagem e o Ensino de Ciências: do Conhecimento Cotidiano ao Conhecimento Científico. Porto Alegre: Artmed, p. 138-188, 2009.

QUINTO, T.; FERRACIOLI, L. Modelos e modelagem no contexto do ensino de ciências no Brasil: uma revisão de literatura de 1996-2006. Revista Didática Sistêmica, Rio Grande, v. 8, p. 80-100, julho a dezembro de 2008 .

SANTANA, O. A.; NETO, A. F. F.; MOZENA, E. Ciências Naturais - $9^{\circ}$ ano. Editora Saraiva, ed. $3^{\circ}$, São Paulo, 2009.

SCHNETZIER, R. P.; ARAGÃO, R. M. R. Importância, sentido e contribuições de pesquisas para o ensino de Química. Química Nova na Escola, n. 1, p. 27-31, maio de 1995.

SHIMABUKURO, V. (Editora responsável). Projeto Araribá - Ciências - $9^{\circ}$ ano. Editora Moderna, ed. $3^{\text {a }}$, São Paulo, 2010.

SILVA, L. H. A.; ZANON, L. B. Experimentação no ensino de ciências. Em: SCHNETZER, R. P.; ARAGÃO, R. M. R. (Org). Ensino de Ciências: fundamentos e abordagens. Campinas: R.Vieira Gráfica, p. 120-153, 2000.

SILVA, M. C.; QUELUZ, G. Noções das relações entre o ensino de ciências e os acontecimentos históricos que envolvem a ciência, a tecnologia e o ambiente. Coletânea "Educação e Tecnologia”, Curitiba, Editora do CEFET- PR, p. 49-69, 2003.

SILVA, R. R.; MACHADO, P. F. L.; TUNES, E. Experimentar Sem Medo de Errar. Em: SANTOS, W. L. P.; MALDANER, O. A. (Org). Ensino de Química em Foco. Rio Grande do Sul: Unijuí, 2011.

SISDEAPUCARANA. Aula 1 vídeo complementar teoria atômica experimento de Rutherford. Disponível em: <http://www.youtube.com/watch?v=CRU1ltJs2SQ>. Acesso em: 27 de maio de 2014.

TRIVELLATO JÚNIOR, J. et al. Ciências, natureza e cotidiano - $9^{\circ}$ ano. Editora FTD, ed. 2a , São Paulo, 2012.

TUNES, E.; TOLENTINO, M.; SILVA, R. R.; SOUZA, E. C. P.; ROCHA FILHO, R. C. Ensino de Conceitos em Química. IV Sobre a Estrutura Elementar da Matéria. Química Nova, vol. 12, n. 2, p. 199-202, 1989. 
USBERCO, J. et al. Companhia das Ciências- $9^{\circ}$ ano. Editora Saraiva, ed. $2^{\mathrm{a}}$, São Paulo, 2012.

WARTHA, E. J.; SILVA, E. L. S.; BEJARANO, N. R. R. Cotidiano e Contextualização no Ensino de Química. Química Nova na Escola, vol. 35, n. 2, p. 84-91, maio de 2013. 


\section{APÊNDICES}

\section{Apêndice A}

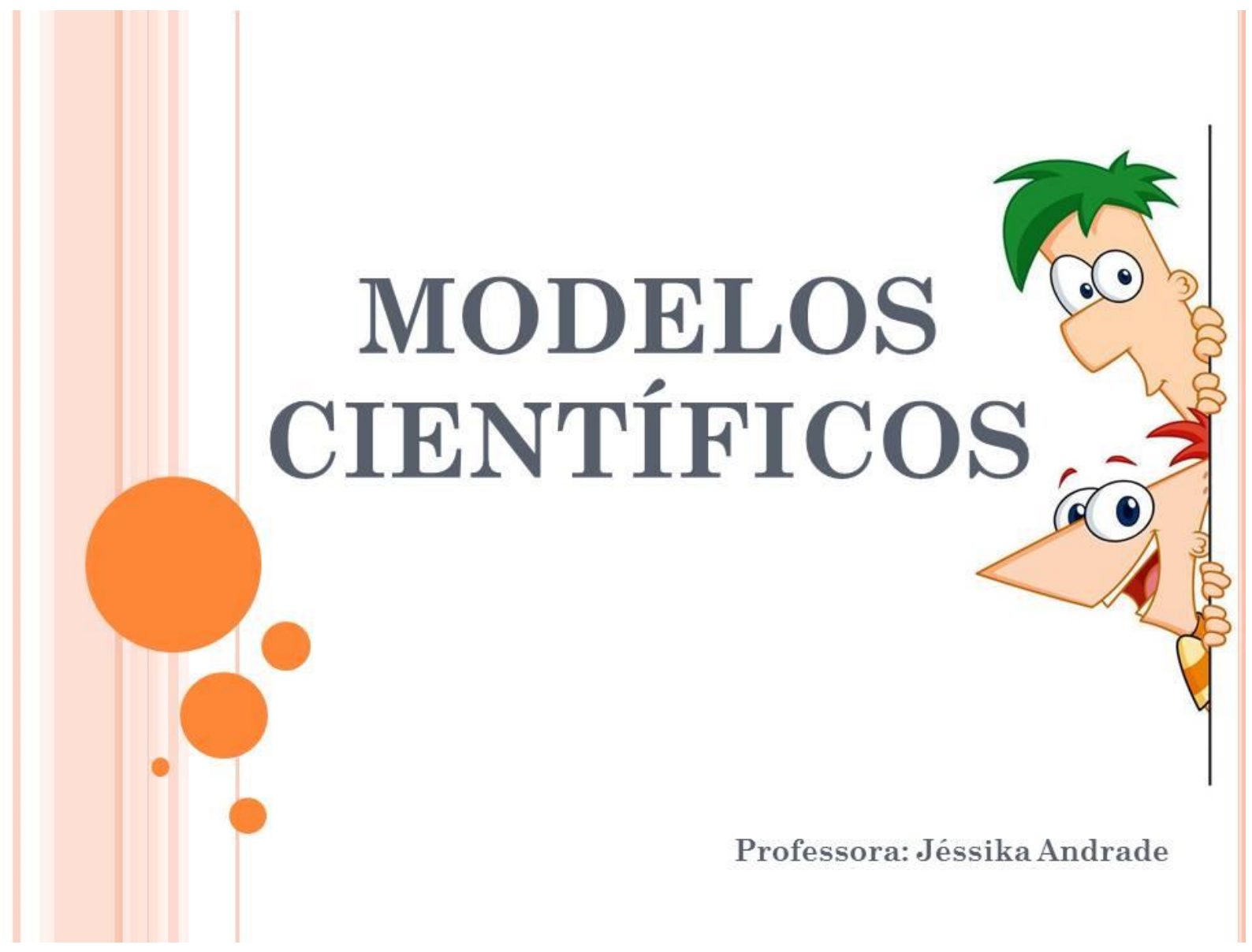


Apêndice B

\section{O QUE SÃO MODELOS?}

Segundo Ferreira e Justi (2008), um modelo pode ser definido como:

[...] uma representação parcial de um objeto, evento, processo ou ideia, que é produzida com propósitos específicos como, por exemplo, facilitar a visualização; fundamentar elaboração e teste de novas ideias; e possibilitar a elaboração de explicações e previsões sobre comportamentos e propriedades do sistema modelado (p. 32). 


\section{Apêndice C}

O QUE É IMPORTANTE SABER SOBRE OS MODELOS?

- Os modelos não são entes reais que a tecnologia e a pesquisa em química permitiram descobrir ou ver;

- Os modelos são representações parciais, ou seja, não são cópias da realidade e possuem limitações;

- Os modelos são criação humana;

- O ente representado pode ou não ser visualizado;

- Os modelos possuem objetivos diferentes dependendo da entidade representada e do público alvo;

- Os modelos podem e são aperfeiçoados ao longo do tempo, incorporando assim, alterações. 


\section{Apêndice D}

Centro Educacional 03 de Sobradinho

Professora: Jéssika Andrade

Disciplina: Ciências

Série/Turma: 8a "B"

Aluno: $n^{\circ}$ :

Data:

\section{Introdução aos modelos atômicos}

Desde muito tempo atrás as pessoas já se perguntavam a respeito da constituição da matéria. Afinal, do que as coisas são feitas? Essa pergunta intrigou muitas pessoas. Vários filósofos e estudiosos da época fizeram suposições para tentar responder a essa pergunta. Empédocles e Aristóteles, dois filósofos gregos, por volta de 500 a.C. tinham uma teoria que por muito tempo foi aceita. Para eles a matéria era constituída pela combinação de quatro elementos da natureza (o termo elemento aqui tem significado diferente do que é atribuído pela química atualmente): água, ar, terra e fogo. Além dessa, muitas outras suposições foram feitas.

Algum tempo depois, por volta de 450 a.C., Demócrito e Leucipo também propuseram uma resposta a essa pergunta. Eles tinham a ideia de que se a matéria fosse dividida várias e várias vezes chegaria um momento que ela seria tão pequena que não seria mais possível dividi-la. Para esses estudiosos essa partícula indivisível, em suas variadas formas e tamanhos, constituiriam todas as coisas. A essa partícula muitíssimo pequena foi dada o nome de átomo, que no grego significa indivisível.

Mas até meados do século XIX o atomismo ainda não era aceito pela comunidade científica. Até esse momento as proposições feitas a respeito da constituição da matéria eram apenas filosóficas, ou seja, eram baseadas em questionamentos. No início desse século o cientista John Dalton propôs uma teoria em que a matéria seria de fato formada por átomos. Essa teoria ficou conhecida como Teoria Atômica de Dalton. Ainda assim, levou algum tempo para que a comunidade científica considerasse a teoria de Dalton e aprofundasse os estudos no atomismo.

A partir daqui, veremos que, assim como Dalton, outros cientistas utilizaram modelos para representar a estrutura do átomo. Como o átomo é uma partícula impossivel de ser vista os modelos são ferramentas auxiliadoras para o estudo deles. $E$ importante lembrarmos que os modelos não são representações fieis do conceito modelado, até mesmo porque não é possível ver o átomo para comprovar se o modelo está de acordo com ele ou não, mas são uma representação feita a partir das propriedades que podemos perceber ao observar o comportamento da matéria, conforme fizemos na atividade "Imaginando o invisível", você se lembra? 


\section{Apêndice E}

Centro Educacional 03 de Sobradinho

Professora: Jéssika Andrade

Disciplina: Ciências Série/Turma: $8^{\mathrm{a}}$ "B"

Aluno: $\mathrm{n}^{\mathrm{o}}$ :

Data:

\section{Avaliação da aprendizagem 1}

1. O que são modelos científicos?

2. Os modelos científicos atualmente aceitos pela comunidade científica são definitivos? Se a sua resposta para essa pergunta tiver sido não, diga o que pode levar a comunidade científica a substituir ou modificar um modelo.

3. Para os filósofos gregos Demócrito e Leucipo o que seria o átomo? 


\section{Apêndice F}

Centro Educacional 03 de Sobradinho

Professora: Jéssika Andrade

Disciplina: Ciências Série/Turma: $8^{\mathrm{a}}$ "B"

Aluno: $\mathrm{n}^{\mathrm{o}}$ :

Data:

\section{Modelo atômico de Dalton}

No século XIX o cientista John Dalton retomou a teoria proposto há 23 séculos pelos atomistas gregos Leucipo e Demócrito. Nesse momento, auxiliado pelos avanços pelos quais a ciência passou durante esse período, Dalton formulou uma teoria atômica, mas essa teoria não foi aceita imediatamente pela comunidade científica. Levou algum tempo para que essa teoria fosse considerada e para que outros estudiosos aprofundassem os estudos no atomismo.

A teoria atômica de Dalton se baseava nos seguintes postulados:

- Toda matéria é formada por substâncias. As substâncias são formadas por átomos, que são maciços e indivisíveis;

- As substâncias simples são caracterizadas por terem apenas um tipo de átomo. Dessa forma, os átomos de uma mesma substância simples são iguais e têm a mesma massa. Átomos de substâncias simples diferentes são diferentes e têm massas diferentes;

- As substâncias compostas são formadas pela combinação de dois ou mais tipos de átomos diferentes na proporção de números inteiros;

- Dois ou mais átomos podem se combinar de diferentes maneiras e formar mais de um tipo de substância;

- Os átomos não podem ser destruídos nem criados.

Desse modo, o modelo atômico de Dalton é caracterizado como algo pequeno, esférico, maciço, indivisível e indestrutível.

Apesar de novos modelos terem sido propostos depois, algumas ideias de Dalton permanecem até hoje aceitas pela comunidade científica. 
Apêndice G

A Matéria Segundo o Modelo de Dalton

\section{Matéria}

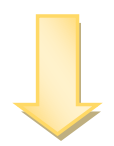

Substâncias
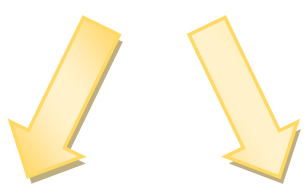

Átomos simples

Átomos compostos

(substâncias simples)

(substâncias compostas) 
Apêndice $H$

Matéria segundo o modelo de Dalton modificado

\section{Matéria}

se apresenta sob a forma de

\section{Materiais}

são porções de matéria que contém duas ou mais

\section{Substâncias}

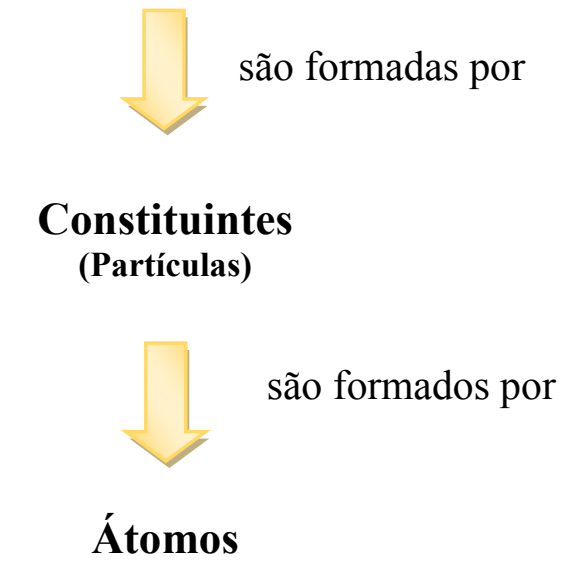




\section{Apêndice I}

Centro Educacional 03 de Sobradinho

Professora: Jéssika Andrade

Disciplina: Ciências Série/Turma: $8^{\mathrm{a}}$ "B"

Aluno: $n^{\circ}$ :

Data:

\section{Modelo atômico de Dalton modificado}

Avogadro fez algumas alterações no modelo proposto por Dalton. Ele propôs em 1811 que o oxigênio e o hidrogênio não eram substâncias monoatômicas (formadas por um único átomo) e, sim, diatômicas (formadas por dois átomos) e que seriam denominadas de moléculas. Assim, o oxigênio seria $\mathrm{O}_{2}$ e o hidrogênio $\mathrm{H}_{2}$. A água seria uma molécula triatômica, ou seja, $\mathrm{H}_{2} \mathrm{O}$.

Assim, a matéria não seria formada diretamente por átomos, mas por partículas (aqui denominadas constituintes). Os átomos manteriam suas características originais conforme proposto por Dalton (esferas maciças indivisiveis). 


\section{Apêndice J}

Centro Educacional 03 de Sobradinho

Professora: Jéssika Andrade

Disciplina: Ciências Série/Turma: 8 a "B"

Aluno: $n^{\circ}:$

Data:

'

\section{Descoberta dos elétrons}

Desde a antiguidade a propriedade de atração entre certos corpos já era conhecida. O filósofo Tales de Mileto já observava que o âmbar, quando atritado com a lã ficava carregado eletricamente. Desse modo, quando tal material era aproximado de outros também eletrizados, se atraiam ou se repeliam. Esses fenômenos eram explicados admitindo a existência da eletricidade, um fluido presente em todos os corpos. Mas o que seria afinal a eletricidade?

O cientista Joseph John Thomson, após inúmeros experimentos realizados por ele e por outros cientistas, descobriu a existência de partículas bem menores que 0 átomo, que estavam presentes em todos os átomos e que tinham carga elétrica negativa. Essas partículas foram chamadas de elétrons. A eletricidade estaria então relacionada ao movimento das cargas elétricas. As cargas elétricas, que podem ser positivas ou negativas (como é o caso dos elétrons), justificariam também a atração $e$ repulsão entre corpos eletrizados. 


\section{Apêndice K}

Centro Educacional 03 de Sobradinho

Professora: Jéssika Andrade

Disciplina: Ciências Série/Turma: $8^{\mathrm{a}}$ "B"

Aluno: $n^{\circ}$ :

Data:

\section{Avaliação da aprendizagem 2}

1. Como Dalton descreve e representa o átomo? Descreva e ilustre.

2. No que se refere à composição, o que diferencia as substâncias simples das substâncias compostas de acordo com o modelo de Dalton?

3. Em relação à constituição da matéria, no que o modelo de Dalton se difere do modelo de Dalton modificado por Avogadro?

4. O que seriam as partículas de acordo com essa modificação?

5. Reescreva o que você entende por modelo científico. 


\section{Apêndice L}

Centro Educacional 03 de Sobradinho

Professora: Jéssika Andrade

Disciplina: Ciências

Série/Turma: 8 a "B"

Aluno: $n^{\circ}$ :

Data:

Avaliação da aprendizagem 3

1. Desde a antiguidade evidências da existência da eletricidade já eram observadas. Que evidências eram essas? Cite três exemplos.

2. O que são os elétrons? 


\section{Apêndice M}

Centro Educacional 03 de Sobradinho

Professora: Jéssika Andrade

Disciplina: Ciências

Série/Turma: $8^{\mathrm{a}}$ "B"

Aluno: $n^{\circ}$ :

Data:

\section{Modelo atômico de Thomson}

Após descobrir os elétrons, Thomson concluiu que eles eram uma parte constituinte do átomo. Então ele propôs um novo modelo atômico. Diferentemente do que acreditavam Demócrito, Leucipo e Dalton o átomo não era indivisível. De acordo com o modelo de Thomson o átomo é uma esfera carregada positivamente com partículas negativas (os elétrons) incrustadas. 


\section{Apêndice N}

Centro Educacional 03 de Sobradinho

Professora: Jéssika Andrade

Disciplina: Ciências Série/Turma: $8^{a}$ "B"

Aluno: $n^{\circ}:$

Data:

\section{Avaliação da aprendizagem 4}

1. No que o modelo atômico de Thomson se difere do modelo atômico de Dalton?

2. De acordo com o modelo atômico de Thomson, como os elétrons estão distribuídos nos átomos?

3. Reescreva o que você entende por elétron. 


\section{Apêndice 0}

Centro Educacional 03 de Sobradinho

Professora: Jéssika Andrade

Disciplina: Ciências Série/Turma: $8^{\mathrm{a}}$ "B"

Aluno: $\mathrm{n}^{\circ}$ :

Data:

$+1$

\section{Modelo atômico de Rutherford}

Rutherford iniciou seus estudos juntamente com Thomson. $O$ modelo atômico proposto por Thomson foi aceito por alguns anos pela comunidade científica, até que Rutherford, ao concluir alguns estudos, propôs um novo modelo agora mais aceito.

Em um experimento, Rutherford e sua equipe bombardearam uma lâmina de ouro muito fina com partículas alfa (que são partículas radioativas que não podem ser vistas e possuem carga positiva), como mostra a imagem abaixo.

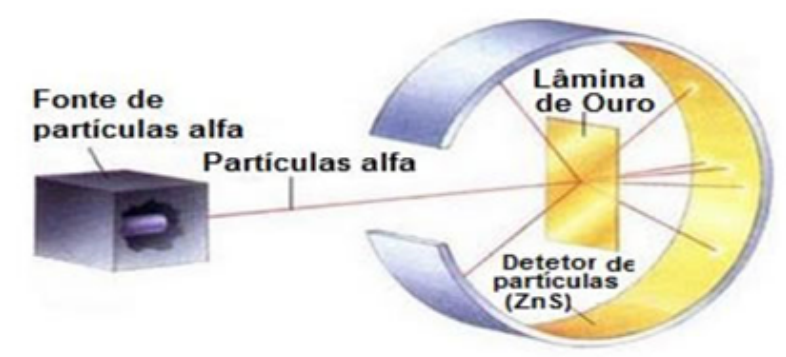

Figura 2: Esquema do experimento de Rutherford com partículas alfa Fonte: Fagoça, 2014.

Durante o experimento foi possivel perceber que:

1. A maioria das partículas atravessava a fina lâmina de ouro;

2. Uma pequena parte das partículas era desviada de sua trajetória e;

3. Uma pequena parte das partículas era ricocheteada.

As partículas não podiam ser vistas, mas era possível detectar seu comportamento porque ao passarem pela placa de ouro $e$ colidirem com a placa de material fosforescente que estava em volta da placa de ouro elas emitiam luz.

Rutherford pôde perceber então que diferentemente do que propunha o modelo de Thomson, o átomo não seria uma esfera de carga positiva incrustada de elétrons. Com base em seu experimento ele deduziu que as partículas que ricocheteavam tinham esse comportamento porque colidiam com outras partículas positivas e eram repelidas. Algumas se desviavam porque apenas se aproximavam de outras partículas positivas. A 


\section{Apêndice $\mathbf{P}$}

maior parte, a que atravessou a lâmina, teve esse comportamento porque de alguma forma encontrou passagem. Mas, como?

Rutherford concluiu que o átomo teria então uma pequena região mais densa onde estariam partículas concentradas, já que apenas uma pequena parte das partículas alfa era ricocheteada. Também deduziu que esta parte mais densa do átomo, a qual chamou de núcleo, possui partículas positivas, já que parte das partículas alfa (também positivas) tinha sua trajetória desviada, o que se explica pela repulsão de cargas semelhantes. Essas partículas do núcleo foram chamadas de prótons.

Rutherford também deduziu que a região menos densa do átomo deveria possuir espaços vazios que permitiriam a passagem das partículas alfa. Nessa região deduziu que ficariam os elétrons, girando em orbitais ao redor do núcleo. Chamou essa região de eletrosfera. Rutherford concluiu também que maior parte da massa do átomo está concentrada no núcleo e que ele é muito pequeno, o que o torna muito denso. 


\section{Apêndice Q}

Centro Educacional 03 de Sobradinho

Professora: Jéssika Andrade

Disciplina: Ciências Série/Turma: 8 "B"

Aluno: $n^{\circ}$ :

Data:

\section{Avaliação da aprendizagem 5}

1. Quais são as características do modelo atômico proposto por Rutherford que se diferenciam do modelo atômico de Thomson?

2. Como Rutherford concluiu que a maior parte do átomo é formada por espaços vazios? 


\section{Apêndice R}

Centro Educacional 03 de Sobradinho

Professora: Jéssika Andrade

Disciplina: Ciências Série/Turma: $8^{\mathrm{a}}$ "B"

Aluno: $\mathrm{n}^{\circ}$ :

Data:

\section{Modelo atômico de Rutherford-Bohr}

O modelo atômico proposto por Rutherford não explicava devidamente o movimento dos elétrons. Se os elétrons estivessem parados seriam atraídos pelo núcleo. Se estivessem em movimento o tempo todo perderiam energia.

Bohr propôs então um novo modelo atômico, que na verdade é o modelo de Rutherford aperfeiçoado, em que os elétrons estariam distribuídos em níveis de energia e nesses níveis se movimentariam sem perda energética. De acordo com esse modelo o átomo possui sete níveis de energia. Ao ganhar ou perder energia os elétrons mudam de um nível para o outro. Nos níveis mais próximos do núcleo a energia é menor e nos níveis mais distantes a energia é maior. 


\section{Apêndice S}

Centro Educacional 03 de Sobradinho

Professora: Jéssika Andrade

Disciplina: Ciências

Série/Turma: 8 " $\mathrm{B}$ "

Aluno: $n^{\circ}$ :

Data:

\section{Avaliação da aprendizagem 6}

1. O que o modelo de Rutherford-Bohr acrescentou ao modelo atômico de Rutherford?

2. Por que, ao longo do tempo, os cientistas propuseram diferentes modelos para representar o átomo?

3. Esse último modelo atômico é definitivo? Justifique.

4. Quais são as principais características do modelo atômico de Dalton, Thomson, Rutherford e Rutherford-Bohr? Descreva e ilustre:
a) Dalton
b) Thomson 


\section{Apêndice T}

c) Rutherford

d) Rutherford-Bohr

5. Muitas pessoas acreditavam que a ciência era sempre correta e absoluta. $\subseteq$ você, como caracteriza o conhecimento científico? 
Apêndice U

Proposição didática sobre modelos atômicos. 


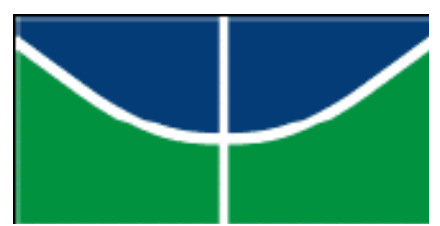

\title{
UNIVERSIDADE DE BRASÍLIA
}

Instituto de Ciências Biológicas

Instituto de Física

Instituto de Química

Faculdade UnB Planaltina

Programa de Pós-Graduação em Ensino de Ciências

Mestrado Profissional em Ensino de Ciências

\section{O ENSINO DE MODELOS ATÔMICOS NO 9 ANO: UMA PROPOSTA}

\author{
JÉSSIKA SILVA DE ANDRADE
}

Proposição de ação profissional resultante da dissertação realizada sob orientação da Prof. ${ }^{a}$ Dr. ${ }^{a}$ Renata Cardoso de Sá Ribeiro Razuck e apresentada à banca examinadora como requisito parcial à obtenção do Título de Mestre em Ensino de Ciências - Área de Concentração "Ensino de Química", pelo Programa de Pós-Graduação em Ensino de Ciências da Universidade de Brasília. 


\section{APRESENTAÇÃO}

Colega professor (a),

Este material foi elaborado na forma de módulo didático como produto da nossa pesquisa no Mestrado Profissional em Ensino de Ciências. Nele você encontrará um conjunto de textos e atividades elaborados a partir das principais dificuldades enfrentadas por nós, professores, em sala de aula ao lidarmos com conteúdos com elevado nível de abstração.

Esperamos que esse módulo possa contribuir com o ensino de ciências que valorize a formação crítica cidadã recomendada por documentos oficiais - como os Parâmetros Curriculares Nacionais (1998) e as Orientações Curriculares para a Educação Básica do DF (2010) - em que o aluno por meio da apropriação de conhecimentos científicos, seja capaz de participar de forma ativa e crítica das decisões que envolvem o contexto social em que está inserido.

Buscamos por meio de uma abordagem histórica dos conceitos científicos superar o modelo tradicional de ensino por transmissão que favorece a memorização e a aquisição superficial dos conhecimentos e algumas falhas verificadas na abordagem dos conteúdos pelos livros didáticos aprovados pelo Programa Nacional do Livro Didático/2014 e dar subsídios ao professor para que ele possa direcionar as aulas de modo a favorecer a compreensão dos conteúdos.

Sabemos que o módulo por si só não transforma a prática docente, mas é um instrumento disponibilizado para dar suporte a professores que buscam alternativas que possam somar a sua prática e contribuir com o processo de ensino-aprendizagem de conceitos científicos abstratos visando melhorar a qualidade da educação escolar oferecida à nossa comunidade.

Este módulo propõe uma abordagem em seis momentos. Esperamos que ele possa contribuir para uma prática de ensino inovadora que desperte o interesse de nossos alunos e proporcione a aprendizagem de conceitos aceitos cientificamente. 
Professor, antes de iniciarmos a abordagem dos conteúdos referente aos modelos atômicos é importante que nossos alunos compreendam o conceito científico de modelo a fim de prevenir equívocos que possam resultar na não compreensão dos conceitos químicos. Tal conceito será abordado por meio de uma atividade experimental, realizada em grupo pelos estudantes, seguida de discussão. Em seguida, introduziremos o conceito de átomo por meio da utilização de um texto que valoriza aspectos históricos da construção desse conceito.

\section{Imaginando o invisível}

Para esta atividade o professor deve levar para a sala de aula quatro caixas de papelão, que podem ser caixas de sapato. Dentro de cada caixa deve haver um objeto qualquer como, por exemplo, uma esfera, uma chave ou um dado. O objeto deve ser diferente nas quatro caixas. As caixas devem estar encapadas de modo que os alunos não consigam ver o que há dentro delas.

A turma deve ser dividida em quatro grupos e cada grupo deve receber uma caixa. A atividade consiste em cada grupo tentar inferir o que há dentro da caixa, sem abri-la, é claro, percebendo apenas as propriedades do objeto que podem ser notadas através do manuseio da embalagem.

Durante a atividade os alunos deverão identificar características que possibilitam identificar as propriedades do objeto contido na caixa.

Em seguida, os alunos de cada grupo deverão fazer um desenho (modelo representativo) que melhor represente o objeto que está dentro da caixa. Eles deverão se orientar pelas propriedades destacadas anteriormente. Depois, os alunos dos quatro grupos deverão expor seus modelos para o objeto e as razões que os levaram àquele modelo.

A caixa deve permanecer vedada mesmo após a conclusão da atividade, pois em sequência será discutido o conceito de modelo, e o objetivo de não abrir a caixa é que o aluno tenha a percepção de que, na maioria das vezes, não é possível verificar a correspondência entre o modelo e o modelado a partir da observação visual. 


\section{Discussão do conceito de modelo}

Professor, após a execução da atividade "Imaginando o invisível" é necessário que seja feita uma discussão a respeito do que vem a ser um modelo antes que sejam introduzidos os modelos atômicos, ressaltando, além de seus principais aspectos, suas limitações.

Você pode se embasar no conceito de Ferreira e Justi (2008), que definem modelo como:

[...] uma representação parcial de um objeto, evento, processo ou ideia, que é produzida com propósitos específicos como, por exemplo, facilitar a visualização; fundamentar elaboração e teste de novas ideias; e possibilitar a elaboração de explicações e previsões sobre comportamentos e propriedades do sistema modelado (FERREIRA e JUSTI, 2008, p. 32).

É importante frisar que:

- Os modelos não são entes reais que a tecnologia e a pesquisa em química permitiram descobrir ou ver;

- Os modelos são representações parciais, ou seja, não são cópias da realidade e possuem limitações;

- Os modelos são criação humana;

- O ente representado pode ou não ser visualizado;

- Os modelos possuem objetivos diferentes dependendo da entidade representada e do público alvo;

- Os modelos podem e são aperfeiçoados ao longo do tempo, incorporando assim, alterações.

Professor, ao concluir a discussão sobre modelos, inicie a primeira abordagem sobre o átomo verificando o que os alunos pensam da constituição da matéria. Pergunte a eles do que as coisas são feitas e permita que socializem suas opiniões. Em seguida, sugerimos que conclua a abordagem fazendo a leitura e discussão do texto 1, por nós elaborado. 


\section{Texto 1}

\section{Introdução aos modelos atômicos}

Desde muito tempo atrás as pessoas já se perguntavam a respeito da constituição da matéria. Afinal, do que as coisas são feitas? Essa pergunta intrigou muitas pessoas. Vários filósofos e estudiosos da época fizeram suposições para tentar responder a essa pergunta. Empédocles e Aristóteles, dois filósofos gregos, por volta de 500 a.C. tinham uma teoria que por muito tempo foi aceita. Para eles a matéria era constituída pela combinação de quatro elementos da natureza (o termo elemento aqui tem significado diferente do que é atribuído pela química atualmente): água, ar, terra e fogo. Além dessa, muitas outras suposições foram feitas.

Algum tempo depois, por volta de 450 a.C., Demócrito e Leucipo também propuseram uma resposta a essa pergunta. Eles tinham a ideia de que se a matéria fosse dividida várias e várias vezes chegaria um momento que ela seria tão pequena que não seria mais possível dividi-la. Para esses estudiosos essa partícula indivisivel, em suas variadas formas e tamanhos, constituiriam todas as coisas. A essa partícula muitíssimo pequena foi dada o nome de átomo, que no grego significa indivisível.

Mas até meados do século XIX o atomismo ainda não era aceito pela comunidade científica. Até esse momento as proposições feitas a respeito da constituição da matéria eram apenas filosóficas, ou seja, eram baseadas em questionamentos. No início desse século o cientista John Dalton propôs uma teoria em que a matéria seria de fato formada por átomos. Essa teoria ficou conhecida como Teoria Atômica de Dalton. Ainda assim, levou algum tempo para que a comunidade científica considerasse a teoria de Dalton e aprofundasse os estudos no atomismo.

A partir daqui, veremos que, assim como Dalton, outros cientistas utilizaram modelos para representar a estrutura do átomo. Como o átomo é uma partícula impossível de ser vista os modelos são ferramentas auxiliadoras para o estudo deles. É importante lembrarmos que os modelos não são representações fieis do conceito modelado, até mesmo porque não é possível ver o átomo para comprovar se o modelo está de acordo com ele ou não, mas são uma representação feita a partir das propriedades que podemos perceber ao 
observar o comportamento da matéria, conforme fizemos na atividade "Imaginando o invisível", você se lembra?

No final da aula, após ter concluído a discussão do conceito de modelo e o texto 1 , peça que os alunos respondam a Avaliação da Aprendizagem 1 para que eles possam sintetizar suas ideias e você, professor, possa verificar a aprendizagem deles.

\section{Avaliação da Aprendizagem 1}

1. O que são modelos científicos?

2. Os modelos científicos atualmente aceitos pela comunidade científica são definitivos? Se a sua resposta para essa pergunta tiver sido não, diga o que pode levar a comunidade científica a substituir ou modificar um modelo.

3. Para os filósofos gregos Demócrito e Leucipo o que seria o átomo? 
Professor, levando em consideração que a partir desse momento os alunos compreendem o que são modelos e já possuem uma noção do seu papel no meio científico, abordaremos os conteúdos que envolvem o primeiro modelo atômico, proposto por Dalton, e o modelo atômico de Dalton modificado, proposto por Avogadro, por meio de textos, de sistemas conceituais e da construção de modelos representativos pelos próprios alunos. Para tal, sugerimos a leitura do texto a seguir que foi por nós construído. Durante a leitura sugerimos que discuta cada um dos aspectos da teoria atômica de Dalton ressaltados no texto.

\section{Texto 2}

\section{Modelo atômico de Dalton}

No século XIX o cientista John Dalton retomou a teoria proposto há 23 séculos pelos atomistas gregos Leucipo e Demócrito. Nesse momento, auxiliado pelos avanços pelos quais a ciência passou durante esse período, Dalton formulou uma teoria atômica, mas essa teoria não foi aceita imediatamente pela comunidade científica. Levou algum tempo para que essa teoria fosse considerada e para que outros estudiosos aprofundassem os estudos no atomismo.

A teoria atômica de Dalton se baseava nos seguintes postulados:

- Toda matéria é formada por substâncias. As substâncias são formadas por átomos, que são maciços e indivisíveis;

- As substâncias simples são caracterizadas por terem apenas um tipo de átomo. Dessa forma, os átomos de uma mesma substância simples são iguais e têm a mesma massa. Átomos de substâncias simples diferentes são diferentes e têm massas diferentes:

- As substâncias compostas são formadas pela combinação de dois ou mais tipos de átomos diferentes na proporção de números inteiros; 
- Dois ou mais átomos podem se combinar de diferentes maneiras e formar mais de um tipo de substância;

- Os átomos não podem ser destruídos nem criados.

Desse modo, o modelo atômico de Dalton é caracterizado como algo pequeno, esférico, maciço, indivisível e indestrutível.

Apesar de novos modelos terem sido propostos depois, algumas ideias de Dalton permanecem até hoje aceitas pela comunidade científica.

Professor, uma das dificuldades encontradas no processo de ensino-aprendizagem dos modelos atômicos é o alto grau de abstração dos conteúdos relacionados a esse tema gerado pelo fato de o átomo ser uma realidade impossível de ser vista. Propomos, portanto, que os sistemas conceituais que serão apresentados a seguir e mais adiante sejam reproduzidos em escala maior e acoplado a discussão dos textos 2 e 3 com o objetivo de facilitar a compreensão dos conceitos que envolvem o átomo.

\title{
A Matéria Segundo o Modelo de Dalton
}

\section{Matéria}

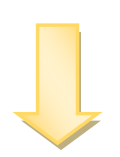

\section{Substâncias}

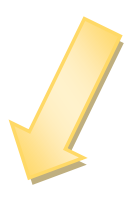

Átomos simples

(substâncias simples)

\begin{abstract}
Átomos compostos
(substâncias compostas)
\end{abstract}

Figura 1: Sistema conceitual que trata da forma de apresentação da matéria segundo o modelo de Dalton. 


\section{Construindo modelos}

Agora é hora de praticar! Após a leitura e discussão dos textos acima, os alunos deverão construir modelos representativos de acordo com as indicações abaixo. Como elucida Justi (2011), não existem regras gerais para a construção de modelos, porém existem etapas inerentes a esse processo. A autora considera que tais etapas são quatro e que estas exercem influência umas sobre as outras. São elas: elaboração, expressão, teste e identificação de abrangência e limitações. O professor deve orientar os alunos no momento da construção dos modelos de acordo com as etapas acima mencionadas, mas deixá-los à vontade para os construírem de acordo com suas próprias percepções. Sugerimos, então, para o alcance dos objetivos proceder com as seguintes etapas:

$\left.1^{\circ}\right)$ Fazer um desenho ou modelar com massinha o modelo atômico proposto por Dalton;

$2^{\circ}$ ) Construir, utilizando palitos de madeira e bolinhas de isopor, modelos que representem substâncias simples e substâncias compostas.

Sugerimos que as substâncias aqui representadas sejam o oxigênio (substância simples), o hidrogênio (substância simples) e a água (substância composta) que de acordo com o modelo de Dalton podem ser representadas como no exemplo a seguir:

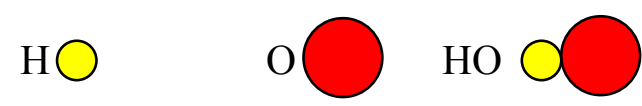

Professor, os materiais necessários para a elaboração dos modelos deverão ser providenciados previamente. Serão necessários: folhas brancas, massinha de modelar, palitos de madeira e bolinhas de isopor de tamanhos variados. Caso seja viável, você pode optar por pedir que os alunos providenciem e tragam de casa. Ressaltamos ainda a importância de trabalhar com um tempo previsto para cada atividade, isso o auxiliará para que todo o conteúdo seja abordado sem atropelos. Em sequência sugerimos a leitura coletiva do texto 3 e a utilização do sistema conceitual para auxiliar no momento da explicação e discussão. 


\section{Modelo atômico de Dalton modificado}

Avogadro fez algumas alterações no modelo proposto por Dalton. Ele propôs em 1811 que o oxigênio e o hidrogênio não eram substâncias monoatômicas (formadas por um único átomo) e, sim, diatômicas (formadas por dois átomos) $e$ que seriam denominadas de moléculas. Assim, o oxigênio seria $\mathrm{O}_{2}$ e o hidrogênio $\mathrm{H}_{2}$. A água seria uma molécula triatômica, ou seja, $\mathrm{H}_{2} \mathrm{O}$.

Assim, a matéria não seria formada diretamente por átomos, mas por partículas (aqui denominadas moléculas). Os átomos manteriam suas características originais conforme proposto por Dalton (esferas maciças indivisíveis).

\section{Matéria segundo o modelo de Dalton modificado}

\section{Matéria}

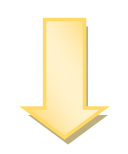

\section{Substâncias}

\section{Substâncias simples Substâncias compostas}

$\begin{array}{cc}\text { Moléculas } & \begin{array}{c}\text { Moléculas } \\ \text { diatômicas }\end{array}\end{array}$

Figura 2: Sistema conceitual que trata da forma de apresentação da matéria segundo o modelo de Dalton modificado. 
O sistema conceitual representado pela figura 2 faz referência ao proposto por Chaib (1988).

\section{Construindo modelos}

Agora é hora de praticar! Após a leitura e discussão do texto 3, os alunos deverão construir modelos representativos para substâncias simples e substâncias compostas segundo o modelo de Dalton modificado. Sugerimos que as substâncias aqui representadas sejam as mesmas representadas para o modelo de Dalton, oxigênio, hidrogênio e água $\left(\mathrm{H}_{2}, \mathrm{O}_{2}\right.$ e $\left.\mathrm{H}_{2} \mathrm{O}\right)$.

Após concluírem a construção dos modelos, permita que os alunos socializem e discutam com os demais colegas a respeito de seus modelos e depois peça que eles respondam a Avaliação da Aprendizagem 2.

\section{Avaliação da Aprendizagem 2}

1. Como Dalton descreve e representa o átomo? Descreva e ilustre.

2. No que se refere à composição, o que diferencia as substâncias simples das substâncias compostas de acordo com o modelo de Dalton?

3. Em relação à constituição da matéria, no que o modelo de Dalton se difere do modelo de Dalton modificado por Avogadro?

4. O que seriam as partículas de acordo com essa modificação?

5. Reescreva o que você entende por modelo científico. 
Professor, este momento antecede a abordagem do modelo atômico de Thomson. Dentro da proposta de abordagem histórica dos modelos atômicos é importante que os alunos compreendam o contexto da descoberta dos elétrons antes que esses apareçam no modelo proposto por Thomson. É o que faremos nesse momento por meio de um texto, de atividades experimentais e da construção de modelos.

Sugerimos que as atividades experimentais dispostas a seguir sejam realizadas antes da leitura e discussão do texto. A intenção é que haja um momento de discussão e levantamento de hipóteses relacionadas aos experimentos antes que sejam dadas explicações pelo professor, que deve direcionar a discussão e induzir a participação dos alunos.

\section{Atividades experimentais}

\section{Atritando corpos}

Esta atividade consiste em duas partes, uma que demonstra a atração e a outra que demonstra a repulsão entre dois corpos. Para demonstrar a repulsão é necessário providenciar apenas linha, balão e canudo. $\mathrm{O}$ canudo deve ser amarrado à extremidade da linha e segurado pela extremidade oposta de forma que fique pendurado. Em seguida, deve-se encher o balão, atritá-lo com o cabelo e aproximá-lo do canudo (peça o auxílio de alunos voluntários). Observe o que acontece.

Para demonstrar a atração será necessário providenciar uma régua e pequenos pedacinhos de papel picado. Para realizar a atividade basta atritar a régua com o cabelo e em seguida aproximá-la dos pedaços de papel. Observe o que acontece.

Professor, ao concluir esta atividade é importante que se discuta com os alunos o porquê do comportamento ocorrido nas duas demonstrações conduzindo-os a levantar hipóteses. É importante que fique claro durante a discussão que quando um objeto é atritado a outro um deles arranca elétrons do outro ficando assim carregado eletricamente. Se as cargas dos objetos aproximados são opostas (um com carga positiva e o outro com carga negativa) então esses irão se atrair. Porém, se as cargas são iguais (ambas positivas ou ambas negativas) os objetos irão se repelir. 


\section{Esfera de raios}

Essa atividade é demonstrativa e as carteiras em sala de aula devem estar dispostas de tal modo que facilite a observação pelos alunos. Será necessário providenciar uma "esfera de raios". Com esse equipamento é possível visualizar os efeitos produzidos pela corrente elétrica ao passar por um gás. Ela arranca elétrons, ao colidir com os átomos do gás, e permite que percebamos um efeito visual.

Professor, ao discutir essa atividade é importante ficar claro que a condução da corrente elétrica se dá devido à existência de partículas menores nos átomos.

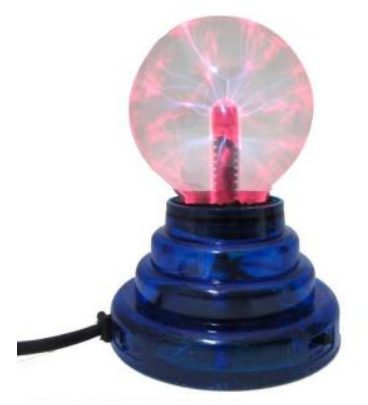

Figura 3: Esfera de raios.
A esfera de raios (figura 3) é um equipamento de custo não muito elevado. Mas para evitar gastos sugerimos que o professor providencie uma emprestada. É possível encontrá-la em algumas escolas e em laboratórios de universidades. Se há alguma próxima a você sugerimos uma busca.

Fonte: Brasil esotérico, 2015.

Observação: Professor, não somente nessas, mas em todas as atividades experimentais desenvolvidas nesse módulo é importante certificar-se que os alunos estão compreendendo os conceitos intrínsecos de cada experimento. É preciso ter cuidado com o que Bachelard (1996) chama de experiência primeira, que é a apreciação do experimento sem relação com a explicação científica. Os alunos tendem a ficar impressionados com os efeitos visuais gerados em alguns experimentos, porém é preciso desviar a atenção e dar a devida ênfase aos objetivos de cada atividade.

Depois de realizar e discutir as atividades experimentais sugerimos a leitura coletiva do texto 4 , por nós elaborado. 


\section{Texto 4}

\section{Descoberta dos elétrons}

Desde a antiguidade a propriedade de atração entre certos corpos já era conhecida. O filósofo Tales de Mileto já observava que o âmbar, quando atritado com a lã ficava carregado eletricamente. Desse modo, quando tal material era aproximado de outros também eletrizados, se atraiam ou se repeliam. Esses fenômenos eram explicados admitindo a existência da eletricidade, um fluido presente em todos os corpos. Mas o que seria afinal a eletricidade?

$O$ cientista Joseph John Thomson, após inúmeros experimentos realizados por ele e por outros cientistas, descobriu a existência de partículas bem menores que o átomo, que estavam presentes em todos os átomos e que tinham carga elétrica negativa. Essas partículas foram chamadas de elétrons. A eletricidade estaria então relacionada ao movimento das cargas elétricas. As cargas elétricas, que podem ser positivas ou negativas (como é o caso dos elétrons), justificariam também a atração e repulsão entre corpos eletrizados.

Após concluir os procedimentos para esse momento, peça que os alunos respondam a Avaliação da Aprendizagem 3, disposta a seguir.

\section{Avaliação da Aprendizagem 3}

1. Desde a antiguidade evidências da existência da eletricidade já eram observadas. Que evidências eram essas?

2. O que são os elétrons? 
Professor, agora que os alunos já estão familiarizados com os elétrons podemos apresentar a eles o modelo atômico proposto por Thomson, dando continuidade a sequência histórica dos modelos atômicos. Essa abordagem será feita por meio de um pequeno texto, do uso de analogia e da construção de modelos pelos próprios alunos.

\section{Bolo formigueiro}

Ao iniciar a aula convide os alunos para participarem de um lanche. Mas esse lanche não pode ser feito com alimentos quaisquer. Deve ser providenciado um "bolo formigueiro" (que dê para todos os alunos), conforme ilustrado na figura 4, que será utilizado em uma analogia logo adiante. No momento em que o modelo de Thomson for apresentado por meio do texto sugerimos que o bolo seja utilizado como analogia para comparar os elétrons incrustados na esfera carregada positivamente, como propõe Thomson, com os granulados incrustados na massa branca do bolo.

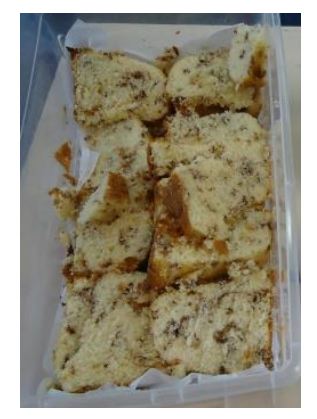

O bolo formigueiro (figura 4) é comum, de preço popular e geralmente encontrado com facilidade nas padarias. Caso você não o encontre pronto, também é de fácil fabricação. Basta acrescentar granulados a qualquer bolo de massa branca que após assado e cortado terá aparância similar a da figura. Você também pode substituí-lo por panetone, por exemplo, ou por qualquer outra massa que apresente aspecto similar.

Figura 4: Bolo formigueiro.

Observação: A analogia deve ser feita de forma cuidadosa. É importante ressaltar não só as semelhanças, como também as diferenças entre os domínios analisados e evidenciar as limitações da analogia para que o uso da mesma não gere ou reforce concepções não aceitas cientificamente. Sugerimos que sejam discutidos outros tipos de analogia para que o aluno possa compreender, primeiramente, o que é uma analogia. Uma das concepções que devem 
ser evitadas é a de que os elétrons estão estáticos no átomo, conforme os alunos tendem a pensar. Prossiga com a leitura e discussão do texto 5.

\section{Texto 5}

\section{Modelo atômico de Thomson}

Após descobrir os elétrons. Thomson concluiu que eles eram uma parte constituinte do átomo. Então ele propôs um novo modelo atômico. Diferentemente do que acreditavam Demócrito, Leucipo e Dalton o átomo não era indivisível. De acordo com o modelo de Thomson o átomo é uma esfera carregada positivamente com partículas negativas (os elétrons) incrustadas.

\section{Construindo modelos}

Agora é hora de praticar! Nesse momento os alunos deverão construir modelos representativos com massinha de modelar e miçangas ou, se preferirem, em forma de desenho numa folha de papel do modelo atômico de Thomson segundo suas próprias concepções. Professor, sugerimos que os alunos façam essa atividade sem o auxílio do livro didático para que eles não sejam influenciados pelas imagens disponíveis nos livros.

Após concluírem os modelos, dê a eles um tempo para que possam socializar suas produções com os colegas e peça que respondam a Avaliação da Aprendizagem 4.

\section{Avaliação da Aprendizagem 4}

1. No que o modelo atômico de Thomson se difere do modelo atômico de Dalton?

2. De acordo com o modelo atômico de Thomson, como os elétrons estão distribuídos nos átomos?

3. Reescreva o que você entende por elétron. 
Professor, já estamos em uma etapa avançada da nossa abordagem. É importante que após cada uma delas você se certifique das concepções que os alunos estão formando a respeito dos conceitos abordados. Sugerimos que ao recolher as avaliações da aprendizagem você avalie as respostas dos alunos e reflita se elas estão coerentes com os objetivos propostos. Caso haja necessidade, antes de dar prosseguimento à próxima etapa, retome os conceitos que ainda possam estar confusos. Após a verificação dê prosseguimento as etapas seguintes.

Abordaremos nesse momento o modelo atômico de Rutherford por meio de um texto, de um vídeo, de atividades experimentais e da construção de modelos.

Para que os alunos compreendam melhor a dinâmica do experimento realizado por Rutherford sugerimos que inicialmente seja apresentado o vídeo disponível no link $<$ http://www.youtube.com/watch?v=CRU1ltJs2SQ>. É um vídeo curto, com aproximadamente dois minutos de duração, o que permite repetir a visualização caso ache necessário. O vídeo ilustra e explica o experimento realizado por Rutherford e também suas deduções. Em seguida, sugerimos a leitura do texto 5, por nós elaborado.

\section{Texto 6}

\section{Modelo atômico de Rutherford}

Rutherford iniciou seus estudos juntamente com Thomson. $O$ modelo atômico proposto por Thomson foi aceito por alguns anos pela comunidade científica, até que Rutherford, ao concluir alguns estudos, propôs um novo modelo agora mais aceito.

Em um experimento, Rutherford e sua equipe bombardearam uma lâmina de ouro muito fina com partículas alfa (que são partículas radioativas que não podem ser vistas e possuem carga positiva), como mostra a imagem abaixo. 


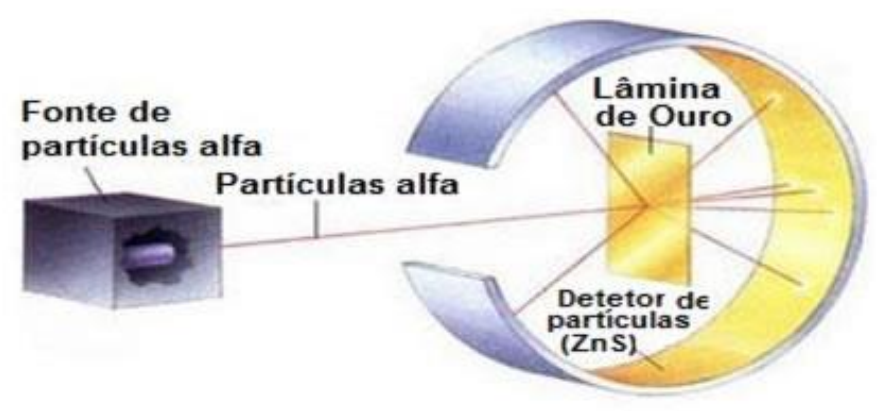

Figura 1: Esquema do experimento de Rutherford com partículas alfa.

Fonte: Fagoça, 2014.

Durante o experimento foi possivel perceber que:

1. A maioria das partículas atravessava a fina lâmina de ouro;

2. Uma pequena parte das partículas era desviada de sua trajetória e;

3. Uma pequena parte das partículas era ricocheteada.

As partículas não podiam ser vistas, mas era possível detectar seu comportamento porque ao passarem pela placa de ouro e colidirem com a placa de material fosforescente que estava em volta da placa de ouro elas emitiam luz.

Rutherford pôde perceber então que diferentemente do que propunha 0 modelo de Thomson, o átomo não seria uma esfera de carga positiva incrustada de elétrons. Com base em seu experimento ele deduziu que as partículas que ricocheteavam tinham esse comportamento porque colidiam com outras partículas positivas e eram repelidas. Algumas se desviavam porque apenas se aproximavam de outras partículas positivas. A maior parte, a que atravessou a lâmina, teve esse comportamento porque de alguma forma encontrou passagem. Mas, como?

Rutherford concluiu que o átomo teria então uma pequena região mais densa onde estariam partículas concentradas, já que apenas uma pequena parte das partículas alfa era ricocheteada. Também deduziu que esta parte mais densa do átomo, a qual chamou de núcleo, possui partículas positivas, já que parte das partículas alfa (também positivas) tinha sua trajetória desviada, o que se explica pela repulsão de cargas semelhantes. Essas partículas do núcleo foram chamadas de prótons.

Rutherford também deduziu que a região menos densa do átomo deveria possuir espaços vazios que permitiriam a passagem das partículas alfa. Nessa 
região deduziu que ficariam os elétrons, girando em órbitas ao redor do núcleo. Chamou essa região de eletrosfera. Rutherford concluiu também que maior parte da massa do átomo está concentrada no núcleo e que ele é muito pequeno, o que o torna muito denso.

Professor, para que os alunos possam melhor compreender o caráter descontínuo da matéria desenvolva as atividades experimentais dispostas abaixo.

\section{Atividades experimentais}

\section{Pra onde foi o sal?}

Essa atividade consiste em dissolver uma quantidade de sal pré-determinada em água. A água deve ser colocada em um copo medidor e o sal deve ser adicionado numa proporção em que todo ele seja dissolvido. Ao adicionar o sal é previsto que se observe que o volume de água não foi alterado. Então pergunte aos alunos: Pra onde foi o sal? Conduza a discussão induzindo ao máximo a participação dos alunos. É importante que no fim fique claro que o sal ao se dissolver na água preencheu os espaços vazios presentes nos átomos, já discutido anteriormente.

\section{Em busca de espaços vazios}

Providencie um recipiente de vidro (como um copo), um pouco de feijão (suficiente para encher o recipiente) e um pouco de açúcar.

1. Com o recipiente ainda no estado inicial pergunte aos alunos se há nele espaços vazios;

2. Encha o recipiente por completo com grãos de feijão e pergunte novamente aos alunos se há nele espaços vazios;

3. Despeje uma porção de açúcar (o quanto der, sem que derrame) no recipiente e volte a perguntar para os alunos se há nele espaços vazios;

Essa segunda atividade experimental consiste em um modelo da dissolução do sal realizada na atividade anterior, em que o feijão representa as moléculas da água e o açúcar representa o sal. Utilize-a para explicar aos alunos o que aconteceu com o sal e não se esqueça de ressaltar a existência dos espaços vazios. 


\section{Enchendo balão sem assoprar}

Esse experimento consiste em prender a boca de um balão na boca de uma garrafa de forma que o balão vede a garrafa. Em seguida, a garrafa deve ser aquecida com um secador de cabelo. O aquecimento gradual da garrafa encherá o balão. Mais uma vez discuta o experimento com os alunos e permita que eles levantem hipóteses antes de dar qualquer explicação que responda aos questionamentos. Ao final da discussão é importante que os alunos atribuam o fenômeno visualizado ao distanciamento entre as partículas do ar e não ao seu crescimento, como é comum.

Professor, você pode ainda representar a existência dos espaços vazios em sólidos e líquidos. Para tanto, sugerimos os seguintes exemplos:

- Sólidos: Anel de Gravesande

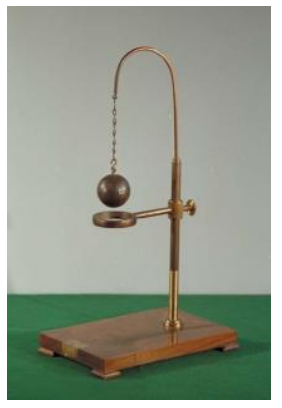

A esfera metálica representada na figura 4 à temperatura ambiente passa pelo círculo que está logo abaixo. Porém quando a esfera é aquecida há um distanciamento entre os átomos do metal, aumentando assim os espaços vazios e fazendo com que a esfera dilate. Desse modo a esfera não passa mais pelo círculo.

Figura 5: Anel de Gravesande.

Fonte: Martins, 2014.

\section{- Líquidos: Termômetro de álcool}

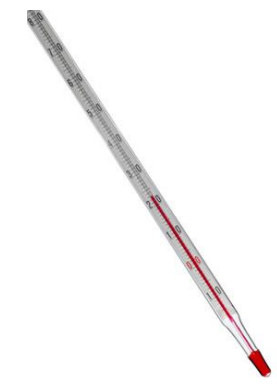

Um fenômeno semelhante ao que ocorre com o Anel de Gravesande acontece aqui. Ao serem aquecidas pela temperatura corporal as moléculas do álcool presente no termômetro se distanciam, o que significa que seus espaços vazios aumentam fazendo assim com que o líquido ocupe um espaço maior no termômetro.

Figura 6: Termômetro de álcool.

Fonte: Silva, 2015. 
É importante que os alunos percebam que por mais que não pareça ou que não possamos ver há sempre espaços vazios, que todas as substâncias possuem espaços vazios entre suas partículas, mesmo que aparentemente sejamos induzidos a pensar diferente, conforme evidenciou o experimento de Rutherford.

\section{Construindo modelos}

Agora é hora de praticar! Nesse momento os alunos deverão construir modelos representativos com massinha de modelar ou, se preferirem, em forma de desenho numa folha de papel para o modelo atômico de Rutherford segundo suas próprias concepções.

Após concluírem os modelos, dê a eles um tempo para que possam socializar suas produções com os colegas e peça que respondam a Avaliação da Aprendizagem 5.

\section{Avaliação da aprendizagem 5}

1. Quais são as características do modelo atômico proposto por Rutherford que se diferenciam do modelo atômico de Thomson?

2. Como Rutherford concluiu que a maior parte do átomo é formada por espaços vazios? 
Professor, esta é a etapa final do nosso módulo. É importante que para introduzir este último momento todas as etapas anteriores tenham sido devidamente executadas para que o aluno possua os subsídios necessários à compreensão desse último modelo e não haja prejuízo da abordagem histórica dos modelos atômicos. O último modelo, proposto por Bohr, que ficou conhecido como modelo atômico de Rutherford-Bohr por ser na verdade uma complementação ao modelo de Rutherford será abordado por meio de um texto, de um experimento e da construção de modelos.

Sugerimos que inicie a aula realizando o experimento a seguir:

\section{Atividade experimental}

\section{Teste de chamas}

Esse experimento é demonstrativo, devendo ser realizado apenas pelo professor e com os cuidados necessários para que não ofereça riscos aos alunos. Os materiais necessários podem ser encontrados em laboratórios de escolas ou universidades.

\section{Material:}

- 5 latinhas de alumínio de refrigerante furadas nas laterais;

- $5 \mathrm{ml}$ de Metanol;

- Pequenas porções de $\mathrm{NaCl}, \mathrm{CuSO}_{4} .5 \mathrm{H}_{2} \mathrm{O}, \mathrm{CaCl}_{2}, \mathrm{LiCl}$ e $\mathrm{SrCl}_{2} \cdot 6 \mathrm{H}_{2} \mathrm{O}$.

Procedimentos:

1. Coloque na parte superior de cada latinha uma das substâncias descritas acima e um pouco de metanol;

2. Com fósforo, acenda uma chama nas latinhas simultaneamente para que os alunos possam observar e comparar as cores das chamas.

Após o experimento é importante discutir com os alunos o porquê das chamas apresentarem cores diferentes levando-os a levantar hipóteses e ao final conduzir a conclusão 
de que esse fato está atribuído à passagem dos elétrons de um nível de energia para o outro e ao retornar emitem luz. É importante também ressaltar que a explicação para a cor das chamas deu origem ao modelo de Rutherford-Bohr. Em seguida, sugerimos a leitura e discussão do texto 6 que foi por nós elaborado.

\section{Texto 7}

\section{Modelo atômico de Rutherford-Bohr}

O modelo atômico proposto por Rutherford não explicava a localização dos elétrons.

Bohr propôs então um novo modelo atômico, que na verdade é o modelo de Rutherford aperfeiçoado, em que os elétrons estariam distribuídos em níveis de energia e nesses níveis se movimentariam sem perda energética. De acordo com esse modelo o átomo possui até sete níveis de energia. Ao ganhar ou perder energia os elétrons mudam de um nível para o outro. Nos níveis mais próximos do núcleo a energia é menor e nos níveis mais distantes a energia é maior.

\section{Construindo modelos}

Agora é hora de praticar! Nesse momento os alunos deverão construir modelos representativos com massinha de modelar ou, se preferirem, em forma de desenho numa folha de papel para o modelo atômico de Rutherford-Bohr segundo suas próprias concepções.

Após concluírem os modelos, dê a eles um tempo para que possam socializar suas produções com os colegas e peça que respondam a Avaliação da Aprendizagem 6.

\section{Avaliação da Aprendizagem 6}

1. O que o modelo de Rutherford-Bohr acrescentou ao modelo atômico de Rutherford?

2. Por que, ao longo do tempo, os cientistas propuseram diferentes modelos para representar o átomo?

3. Esse último modelo atômico é definitivo? Justifique.

4. Quais são as principais características do modelo atômico de Dalton, Thomson, Rutherford e Rutherford-Bohr? Descreva e ilustre. 

a) Dalton;
b) Thomson;
c) Rutherford e;
d) Rutherford-Bohr.

5. Muitas pessoas acreditavam que a Ciência era sempre correta e absoluta. E você, como caracteriza o conhecimento científico? 


\section{REFERENCIAL BIBLIOGRÁFICO}

BACHELARD, G. A formação do espírito científico: contribuição para uma psicanálise do conhecimento. Tradução Esteia dos Santos Abreu. Rio de Janeiro: Contraponto, 316 p., 1996.

BRASIL. Ministério da Educação. Guia de Livros Didáticos PNLD 2014: Ciências, Anos Finais do Ensino Fundamental. Brasília: MEC, 2013.

BRASIL. Ministério da Educação. Parâmetros Curriculares Nacionais: Ciências Naturais. Brasília: MEC, 1998.

Brasil Esotérico, Bola Mágica. Disponível em: <https://www.brasilesoterico.com/produto/ 853/bola-magica-globo-de-plasma-14cm.html>. Acesso em: 22 de fevereiro de 2015.

CHAIB, N. N. Teoria atômico-molecular. Em: HINO, H.; HANAZAKI, R. T. Ensino de Química: dos Fundamentos à Prática. São Paulo: SE/CENP, 1988.

DISTRITO FEDERAL. Secretaria de Educação do Distrito Federal. Currículo da Educação Básica, Anos Finais do Ensino Fundamental. Brasília: SEDF, 2010.

FERREIRA, P. F. M.; JUSTI, R. S. Modelagem e o "Fazer Ciência". Química Nova na Escola, n. 28, p. 32-36, maio de 2008.

FOGOÇA, J. R. V. Experimento de Rutherford. Alunos online, 2014. Disponível em: $<$ http://www.alunosonline.com.br/quimica/experimento-rutherford.html $>$. Acesso em: $25 \mathrm{de}$ maio de 2014.

JUSTI, R. Modelos e Modelagem no Ensino de Química: Um olhar sobre aspectos essenciais pouco discutidos. Em: SANTOS, W. L. P.; MALDANER, O. A. (Org). Ensino de Química em Foco. Rio Grande do Sul: Unijuí, 2011.

MARTINS, L. C. O anel de Gravesande. Mundo físico, 2014. Disponível em: $<$ http://www.mundofisico.joinville.udesc.br/index.php?idSecao $=2 \&$ idSubSecao $=\& i d T e x t o=8$ 6>. Acesso em: 22 de fevereiro de 2015.

SILVA, D. C. M. Conhecendo os termômetros. Alunos online, 2015. Disponível em: $<$ http://www.alunosonline.com.br/fisica/conhecendo-os-termometros.html $>$. Acesso em: 22 de fevereiro de 2015. 
SISDEAPUCARANA. Aula 1 vídeo complementar teoria atômica experimento de Rutherford. Disponível em: <http://www.youtube.com/watch?v=CRU1ltJs2SQ>. Acesso em: 27 de maio de 2014. 